yommin or Yumiria grige in wortheru Cuta; misspelles "Joinasy" ano "Zumuri fion Angel's wistrug. $39: 12.1912$

Han'beine is about 8 mules $N E$ of Laguin del Desoro not farfiom the nives stariabur, at the revthem limit between Matarigas + Santa - Clarar Prommas. Brother Lemís letter also litur y sira. Léon may 17,1928

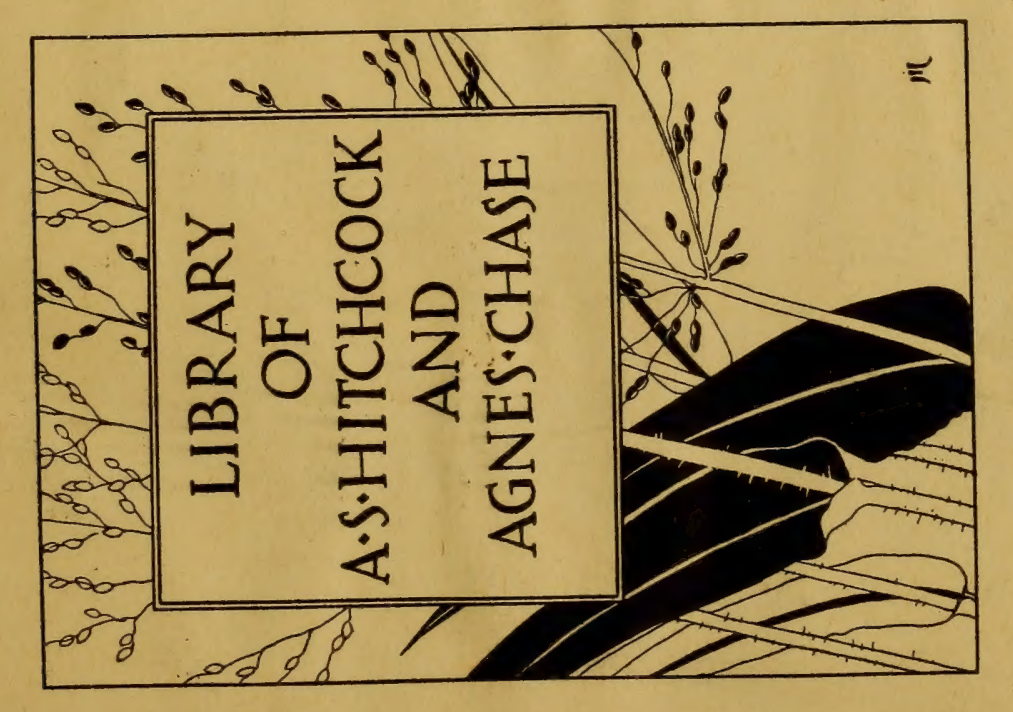





A. S.ttelehouk SMITHSONIAN InStitution be $\$ 0$

UNITED STATES NATIONAL MUSEUM

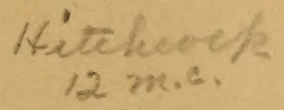

\section{CONTRIBUTIONS}

FROM THE

Initeid States National Herbariud

Volume XII, Part 6

CATALOGue

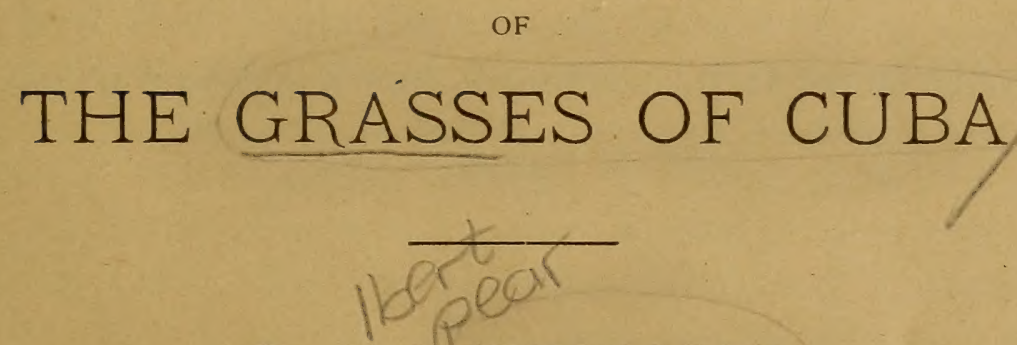

By A. S. HITCHCOCK

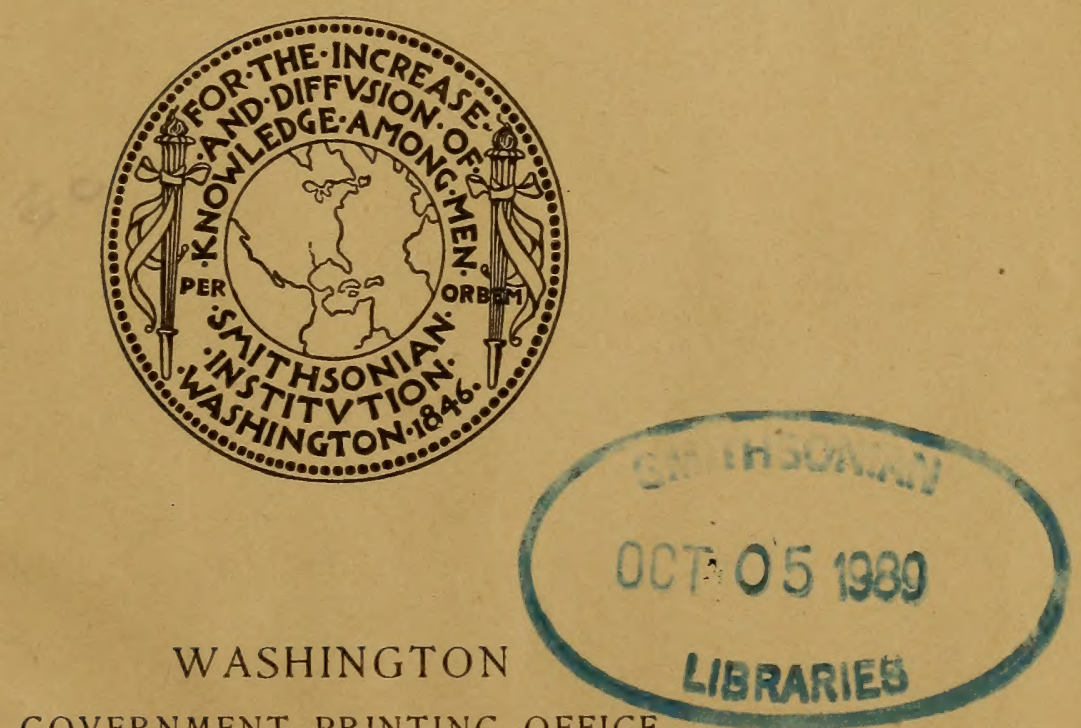

GOVERNMENT PRINTING OFFICE

1909 
BULLETIN OF THE UNITED STATES NATIONAL MUSEUM

IsSUED MARCH 23, 1909

II 


\section{PREFACE.}

The accompanying paper by A. S. Hitchcock, Systematic Agrostologist of the United States Department of Agriculture, entitled Catalogue of the Grasses of Cuba, is the result of an exhaustive study of the material in the United States National Herbarium and in the herbarium of the Estación Central Agronómica de Cuba. It was chiefly through the efforts of Mr. Carl F. Baker, who obtained large - collections in Cuba, that the specimens were made accessible to Mr. Hitchcock. It is hoped that this paper will be followed by similar ones upon other groups.

J. N. Rose, Acting Curator. 



\section{CONTENTS.}

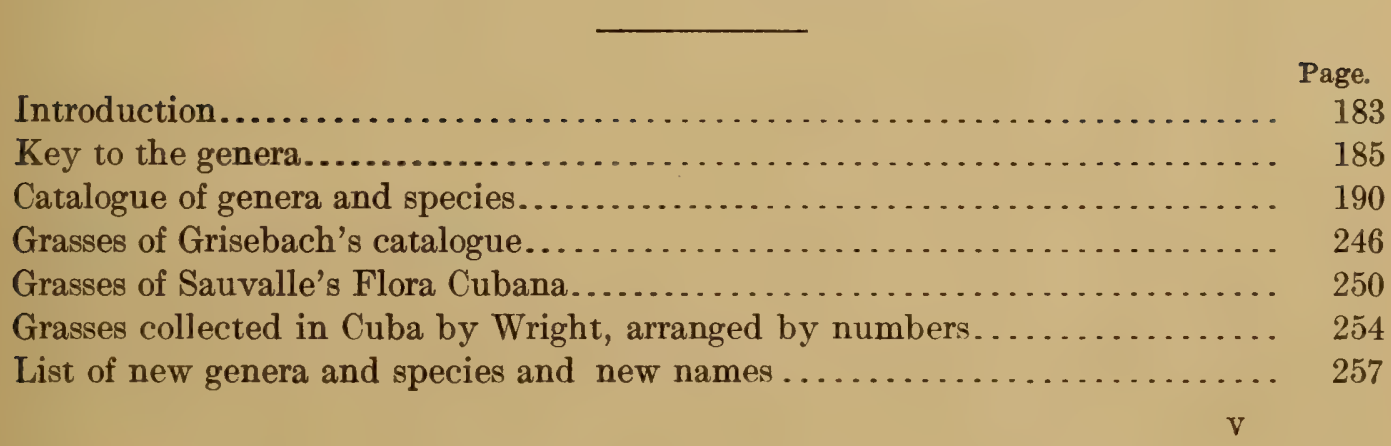





\title{
CATALOGUE OF THE GRASSES OF CUBA.
}

\author{
Ву А. S. Нітснсоск.
}

\section{INTRODUCTION.}

The following list of Cuban grasses is based primarily upon the collections at the Estación Central Agronómica de Cuba, situated at Santiago de las Vegas, a suburb of Habana. The herbarium includes the collections made by the members of the staff, particularly $\mathrm{Mr}$. C. F. Baker, formerly head of the department of botany, and also the Sauvalle Herbarium deposited by the Habana Academy of Sciences. These specimens were examined by the writer during a short stay upon the island in the spring of 1906, and were later kindly loaned by the station authorities for a more critical study at Washington. The Sauvalle Herbarium contains a fairly complete set of the grasses collected by Charles Wright, the most important collection thus far obtained from Cuba. In addition to the collections at the Cuba Experiment Station, the National Herbarium furnished important material for study, including collections made by A. H. Curtiss, W. Palmer and J. H. Riley, A. Taylor (from the Isle of Pines), S. M. Tracy, Brother Leon (De la Salle College, Habana), and the writer.

The earlier collections of Wright were sent to Grisebach for study. These were reported upon by Grisebach in his work entitled "Catalogus Plantarum Cubensium," published in 1866, though preliminary reports appeared earlier in the two parts of Plantae Wrightianae. ${ }^{a}$ During the spring of 1907 I had the opportunity of examining the grasses in the herbarium of Grisebach in Göttingen. ${ }^{b}$ In the present article I have, with few exceptions, accounted for the grasses listed by Grisebach in his catalogue of Cuban plants, and have appended a list of these with references to the pages in the body of this article upon which the species are considered. The numbers upon the labels of the Wright specimens in the Grisebach Herbarium are in many cases not the same as those under which the species were afterwards distributed and under which they were listed in the catalogue. These numbers I have designated as secondary numbers. Grisebach has sometimes connected on his labels the secondary number by the sign

a Mem. Amer. Acad. n. ser. Vol. VIII. Part I, pp. 153 to 192, (as separate) 1860; Part II, pp. 503 to 536, (as separate) 1862. The grasses were included in Part II.

$b$ Unless otherwise stated the writer has examined all the types mentioned in this paper. 
of equality with the distribution number. The data upon the Grisebach labels are meager, usually consisting of the number and year, together with an abbreviation for eastern or western Cuba. The distribution numbers of the grasses reported upon by Grisebach are all below 3500. Wright, after his return from Cuba, studied his collections at the Gray Herbarium and published his results in a series of articles in conjunction with Doctor Sauvalle, of Cuba. ${ }^{a}$ In the

a Anales de la Academia de Ciencias, Médicas, Físicas y Naturales de la Habana, Volumes V to IX, 1868 to 1872 . This was reset and, an index being added, published in 1873 as Flora Cubana. The introduction to the first installment of the series (5: 196. 1868) is as follows: "Revisio Catalogi Grisebachiani vel index plantarum cubensium ad catalogum Cl. Grisebachii anno 1866 editum attemperata, pluribus Wrightianis novis speciebus aucta, valde quoque emendata, a cl. C. Wright; omnia pro Annalibus Regiae Academiae Scientiarum Havanensis digesta, nominibusque adjectis cubensibus vulgo receptis a Francisco A. Sauvalle. Setiembre, 1868." Each continuation is headed "Revisto Catalogi Grisebachiani vel Index Plantarum Cubensium; a Francisco A. Sauvalle." The reprint has a title page as follows: "Flora Cubana. | Enumeratio Nova Plantarum Cubensium | vel | Revisio Catalogi Grisebachiani, | Exhibens |. Descriptiones Generum Specierumque | Novarum | Caroli Wright, (Cantabrigiae) et Francisci Sauvalle, | Synonymis | nominibusque vulgaribus Cubensis adjectis. | Auctore | Francisco A. Sauvalle, | Academiae Scientiarum Havanensis. | Havanae. | Imp. "La Antilla," de cacho-negrete, | Calle de Cuba num. 51. |. 1873.

The Gramineae appeared in Vol. VIII, 1871. The article was entirely reset for the reprint, but a comparison of this portion of the original with the reprint shows very few errors. In the original the serial numbers of the Gramineae occur as follows:

\begin{tabular}{|c|c|c|c|}
\hline Numbers. & Page. & Numbers. & Page. \\
\hline 2721 to $2727 \ldots$ & 157 & 2798 to $2800 .$. & 205 \\
\hline 2728 to $2755 .$. & 158 & 2801 to 2812. & 206 \\
\hline 2756 to $2764 .$. & 200 & 2813 to $2828 \ldots$ & 207 \\
\hline 2765 to $2769 \ldots$ & 201 & 2829 to $2855 \ldots$ & 208 \\
\hline 2770 to $2780 .$. & 202 & 2856 to $2869 \ldots$ & 209 \\
\hline 2781 to 2791. & 203 & 2870 to $2878 \ldots .$. & 287 \\
\hline 2792 to $2797 \ldots$ & 204 & 2879 to $2891 \ldots$ & 288 \\
\hline
\end{tabular}

In the reprint the numbers are as follows:

\begin{tabular}{|c|c|c|c|}
\hline Numbers. & Page. & Numbers, & Page. \\
\hline 2721 to $2737 \ldots$ & 190 & 2799 to 2812 & 197 \\
\hline 2738 to $2764 \ldots$ & 191 & 2813 to $2819 \ldots$ & 198 \\
\hline 2765 to $2769 \ldots$ & 192 & 2820 to 2844 & 199 \\
\hline 2770 to $2776 \ldots$ & 193 & 2845 to 2869 & 200 \\
\hline 2777 to 2789. & 194 & 2870 to $2884 .$. & 201 \\
\hline 2790 to $2796 \ldots$ & 195 & 2885 to $2891 \ldots$ & 202 \\
\hline 2797 to 2798. & 196 & & \\
\hline
\end{tabular}


present paper the new species published in Sauvalle's article are credited to Wright. The original set upon which Sauvalle's list is based is at the Gray Herbarium, and a fairly complete duplicate set is in the Sauvalle Herbarium.

The sets of Wright's plants were made up at the Gray Herbarium and given herbarium distribution numbers. Each number included such collections as were thought to be of the same species. Thus it often occurs that different specimens of the same distribution number may have been collected in different localities or may even belong to different species. The data found upon the field labels in various herbaria are mentioned under each species in the present list. There is also appended a list of the species of grasses included in Sauvalle's Flora Cubana, with references to their identification, and a list of the Wright numbers in sequence with their identification.

The plan followed in the present paper is to give under specimens cited a list of the specimens found in the herbarium of the Estacion Central Agronómica, including the Sauvalle Herbarium, and in the National Herbarium, without statement as to the herbarium in which they are deposited. To these are added specimens found in the Gray Herbarium which do not occur in the herbaria just mentioned, and finally, specimens in the Herbarium of the New York Botanical Garden (Herb. N. Y. Bot. Gard.), including the herbarium of Columbia University, of which the Torrey Herbarium forms a part, which are not found in the others mentioned. The specimens collected by the staff of the botanical department of the Cuba Experiment Station are numbered in a single series and are indicated in this list by the letters HC (Herbarium Cubae). The data for the Wright specimens, given in the paragraph devoted to the enumeration of specimens, are understood to be found with the specimens in the Sauvalle Herbarium. Additional data, found with specimens in other herbaria, are quoted in the succeeding paragraph devoted to notes.

Grisebach enumerated 154 species of grasses in his catalogue. Sauvalle's Flora Cubana includes 170 species. The present list includes 228 species or well-marked subspecies.

\section{KEY TO THE GENERA. ${ }^{a}$}

Series Paniceae.-Spikelets 1-flowered, rarely 2-flowered; when 2-flowered the terminal floret perfect, the lower staminate or neutral (except in Isachne), no apparent internode between them; rachilla articulated below the glumes, the spikelets falling from the pedicels entire, singly, in groups, or together with joints of an articulate rachis; spikelets not laterally compressed (except in Lithachne).

Lemma and palea (the latter sometimes wanting in Andropogoneae) hyaline; glumes more or less indurated, the first largest; sterile lemma like fertile lemma in texture (except in Alloteropsis).

$a$ In this key the tribal characters are given with reference to the Cuban genera only, and in some cases would not hold good for the entire tribe. 
Staminate and pistillate spikelets in different inflorescences; pistillate spikelets inclosed in a bony bead-like involucre (MAYDEAE)........... . Coix (p. 190).

Spikelets all perfect, or unisexual and arranged in pairs, the pistillate sessile, the staminate pedicellate (or all pedicellate in Trachypogon). (ANDropogonEAE.) Joints of the rachis much thickened and excavated to receive the spikelets. First glume of the perfect spikelet flat or somewhat convex; perennials.

6. Manisuris (p. 191).

First glume of the perfect spikelet hemispherical, pitted; annual.

7. Hackelochloa (p. 191).

Joints of rachis not thickened nor excavated for the reception of the spikelets. Spikelets all alike, perfect; inflorescence a plume-like panicle.

Axis of racemes continuous, not articulate; spikelets awnless.

Axis of racemes articulated.

2. Imperata (p. 190).

Spikelets awnless...................... Saccharum (p. 190).

Spikelets awned...................... Erianthus (p. 190).

Spikelets not alike.

All pedicellate; the perfect long-pedicellate, long-awned, the staminate short-pedicellate, awnless..........8. Trachypogon (p. 191).

Sessile and pedicellate, the former perfect, awned, the latter staminate, empty or wanting.

Perfect spikelets transversely rugose.....5. Ischaemum (p. 191). Perfect spikelets not transversely rugose.

Sessile spikelets not all alike, the first to fifth pairs homogamous; awns $10 \mathrm{~cm}$. long, stout; glumes bearing oil glands, lemon-scented when fresh......13. Heteropogon (p. 196). Sessile spikelets alike throughout.

Racemes of several to many joints, at least some of the racemes sessile............9. Andropogon (p. 192).

Racemes reduced to 1 or 2 joints, all the racemes more or less pedunculate.

Pedicellate spikelets present, usually 2 to each sessile spikelet............10. Holcus (p. 195).

Pedicellate spikelets wanting.

Awns not over $2 \mathrm{~cm}$. long, delicate.

11. Sorghastrum (p. 195).

Awns over $10 \mathrm{~cm}$. long, stout.'

12. Rhaphis (p. 195).

Lemma and palea membranaceous or indurated; sterile lemma when present like the glumes in texture.

Lemma and palea membranaceous; axis of inflorescence not breaking up at maturity.

Spikelets 3 to 5 together, the clusters arranged in spikes, the glumes indurated. (ZoYsIEAE.)

Glumes covered with hooked spines...................14. Nazia (p. 196).

Glumes not spiny, united into a somewhat pitcher-shaped pseudoinvolucre........................15. Anthephora (p. 196).

Spikelets distinct, paniculate. (Tristegineat.)

Fertile lemma awned; rather robust grasses.....16. Arundinella (p. 196).

Fertile lemma awnless; low grass with tuft of involute rather wiry basal

leaves [doubtfully placed in this tribe].........17. Triscenia (p. 198).

Lemma and palea cartilaginous or chartaceous-indurated, conspicuously different in texture from the membranaceous glumes, rarely but little indurated.

(Paniceat.) 
Spikelets unisexual; plants monœecious; blades abruptly contracted into petiole-like bases.

Inflorescence consisting of 2 slender racemes, one staminate the other pistillate, digitate at the summit of a naked culm; leafy stems distinct from the base; plants low ................44. Mniochloa (p. 233).

Inflorescence borne on leafy culms; fruit bony-indurated.

Fruit dorsally compressed; panicles terminal on culms or leafy branches, pistillate spikelets above, staminate spikelets below in same panicle .........................42. Olyra (p. 233).

Fruit laterally compressed, conspicuously gibbous on upper dorsum; panicles all axillary or axillary and terminal, the terminal when present wholly staminate ...............43. Lithachne (p. 233).

Spikelets all perfect.

Spikelets 2 to 4 together sunken in the alternate notches of a broad, thickened rachis; creeping grasses ........41. Stenotaphrum (p. 232).

Spikelets not sunken in notches of a thickened rachis.

Spikelets solitary or in small clusters subtended by an involucre consisting of 1 to many bristles (sterile branches), these sometimes grown together.

Involucre persistent on the axis, spikelets deciduous.

36. Chaetochloa (p. 230).

Involucre deciduous with and attached to the spikelets.

Involucre a spiny bur inclosing 1 to 5 spikelets.

Involucre of distinct bristles.

37. Cenchrus (p. 231).

Involucre of a single sterile branch produced beyond each spikelet ...............40. Paratheria (p: 232).

Involucre of numerous often plumose bristles.

Spikelets not involucrate.

38. Pennisetum (p. 232).

Fruits not rigid, margins of lemma not inrolled.

Inflorescence of slender racemes, divergently digitate at the summit of the culm, both glumes wanting.

Inflorescence paniculate.

18. Reimarochloa (p. 198).

Blades cordate-clasping, fruit open at summit; aquatic or semiaquatic grasses........29. Hymenachne (p. 212).

Blades not cordate-clasping.

Spikelets awned, first glume with a pedicel-like callus..................39. Chaetium (p. 232).

Spikelets awnless; fruits cartilaginous-indurated, papillose, usually dark-colored, lemmas with thin, usually white margins.

Fruit open at the white-margined summit; spikelets tuberculate-hispid between the nerves ........21. Leptocoryphium (p. 207).

Fruit not open nor white-margined at summit.

Sterile lemma like the fertile lemma in texture .......26. Alloteropsis (p. 210).

Sterile lemma like the glumes in texture. Spikelets. clothed with long silky hairs..........25. Valota (p. 210). Spikelets glabrous or pubescent only. 
Fruits indurated-rigid (or if thin not open at the summit nor hyaline-margined).

Spikelets placed with the back of the fruit turned away from the main axis.

First glume and rachilla joint forming a swollen ringlike callus; fruit mucronate or shortly awn-pointed.

22. Eriochloa (p. 207).

First glume present or wanting, not forming a ring-like callus; spikelets in slender racemes.

First glume as long as the spikelet or nearly so; spikelets swollen on the side toward the axis and fitting into alternate hollows; inflorescence a single raceme .............27. Mesosetum (p. 211).

First glume wanting or not over one-fourth the length of the spikelet.

Racemes racemose along the main axis; first glume present......28. Brachiaria (p. 212).

Racemes digitate or subdigitate, first glume wanting...........20. Axonopus (p. 207).

Spikelets with the back of the fruit turned toward the main axis.

Spikelets plano-convex, subsessile in spike-like racemes, typically lacking the first glume (both glumes wanting in $P$. pulchellum).

19. Paspalum (p. 199).

Spikelets unequally biconvex; paniculate, or if racemose the first glume present.

Fertile florets 2............23. Isachne (p. 208).

Fertile floret 1.

Glumes awnless.

Second glume broad and saccate, panicle contracted or spike-like.

30. Sacciolepis (p. 212).

Second glume not broad nor saccate.

Margins of lemma inrolled; no lateral appendages nor excavations at base of fruit.....32. Panicum (p. 214).

Margins of lemma not inrolled; either lateral appendages or excavations at base of fruit.

33. Ichnanthus (p. 228).

Glumes or one of them awned, or cuspidate.

Fruit cuspidate, palea free at the tip; second glume and sterile lemma tapering into an awn or cuspidate print.

31. Echinochloa (p. 213).

Fruit not cuspidate, palea not free; awns arising from a toothed summit.

Spikelets clothed with' rose-colored silky hairs; first glume minute.

34. Tricholaena (p. 229).

Spikelets pubescent with short pale hairs, first glume nearly as long as the second.35. Oplismenus (p. 229). 
Series Poaceae.-Spikelets 1 to many-flowered, the imperfect or rudimentary floret, if any, uppermost; rachilla articulated (except in Oryzeae) above the glumes, which are persistent on the pedicel or rachis after the fall of the florets; when 2 to many-flowered a manifest internode of the rachilla separating the florets and articulated below them; spikelets laterally compressed.

Spikelets articulated below the glumes. (OryzeaE.)

Spikelets unisexual, plants monœecious.

Spikelets in pairs, one large, perfect, sessile, the other small, staminate, longpediceled; the broad oblanceolate blades with transverse veins between the longitudinal nerves........................45. Pharus (p. 234).

Spikelets not in pairs, the staminate and pistillate in different panicles; blades linear, not cross-veined..................46. Luziola (p. 234). Spikelets all perfect.

Glumes wanting, lemma awnless...........48. Homalocenchrus (p. 234). Glumes present.

Glumes minute, awnless; lemma awned except in cultivated forms.

47. Oryza (p. 234).

Glumes about as long as the floret or longer, awned.

Glumes tapering into awns; spikelets, including awns, over $3 \mathrm{~cm}$. long............................49. Achlaena (p. 235).

Glumes awned from the notched apex; spikelets, including awns, scarcely $1 \mathrm{~cm}$. long.................50. Reynaudia (p. 235).

Spikelets articulated above the glumes.

Culms woody, perennial, at least at the base, leaf blades commonly articulated with and deciduous from the sheath. (BAmbuseate)

66. Arthrostylidium (p. 245).

Culms herbaceous, annual, leaf blades not articulated with the sheath.

Inflorescence of 1-sided spikes or racemes, spikelets sessile or nearly so.

(Chlorideae.)

Plants diœcious or monœcious, the staminate awnless, pistillate with numerous awns; low stoloniferous grass........60. Opizia (p. 242).

Plants not diœcious, spikelets all alike.

Spikelets with 1 perfect floret, sometimes 1 or more sterile florets above the perfect one.

No sterile florets, spikelets awnless, spikes slender, digitate.

54. Capriola (p. 238).

One or two sterile florets above the perfect one, spikelets generally awned.

Spikes digitate or approximate in apparent whorls at the summit of the culm................55. Chloris (p. 238).

Spikes remote along the main axis...56. Bouteloua (p. 240).

Spikelets with 2 or 3 perfect florets.

Spikes alternate, more or less remote along the main axis, spikelets not crowded....................59. Leptochloa (p. 241).

Spikes digitate or nearly so, spikelets crowded.

Axis of spike not produced beyond the uppermost spikelet, glumes and lemmas not cuspidate...57. Eleusine (p. 241).

Axis of spike produced into a naked cuspidate point, glumes and lower lemmas cuspidate.58. Dactyloctenium (p. 241).

Inflorescence paniculate, sometimes contracted but spikelets never sessile in 1-sided spikes.

Spikelets 1-flowered. (Agrostideae.)

Lemma awnless.......................53. Sporobolus (p. 237). 
Lemma awned.

Lemma indurated, convolute, awn 3-fid (lateral awns minute or wanting in $A$. scabra) ................. 51. Aristida (p. 235).

Lemmas not indurated, tapering into a capillary awn.

Spikelets 2 to many-flowered. (Festuceat.)

52. Muhlenbergia (p. 237).

Lemmas cleft above into a pappus-like crown of bristles.

Lemmas entire.

61. Pappophorum (p. 242).

Lemmas clothed with long silky hairs, tall, reed-like, diœcious grasses .........................62. Gynerium (p. 242).

Lemmas not clothed with silky hairs:

Lemmas3-nerved, not atall indurated .63. Eragrostis (p.242).

Lemmas many-nerved, somewhat indurated and rigid.

Sterile lemmas 1 to 3 above the glumes; plants not diøecious .....................64. Uniola (p. 245).

Sterile lemmas above glumes none; plants diœcious.

65. Distichlis (p. 245).

\section{CATALOGUE OF GENERA AND SPECIES.}

1. COIX L. Sp. Pl. 972. 1753.

1. Coix lachryma-jobi L. Sp. P1. 972. 1753.

Pinar del Rio, Baker \& Abarca, HC 3686; El Guama, Palmer \& Riley 142.

This is originally from tropical Asia, but is now cultivated for ornament in the warmer regions of both hemispheres, whence it has escaped.

2. IMPERATA Ciril. Pl. Rar. Ic. 2: 26. pl. 11. 1792.

1. Imperata brasiliensis Trin. Mem. Acad. Petersb. VI. 2: 331. 1833.

La Magdalena, Baker HC 4946; Madruga, Britton 630; without locality, Wright 3486; Cienfuegos, Combs 701, in Gray Herbarium; Isle of Pines, Curtiss in 1904 in Herb. N. Y. Bot. Gard.; Pinar del Rio, Shafer 310 in Herb. N. Y. Bot. Gard.

The type in the Trinius Herbarium is from Serra da Lapa, Brazil, though Trinius in the original publication cites merely "V. spp. Brazil." I. caudata Trin., as shown by the type in the Trinius Herbarium, differs in having smaller spikelets (about $2.5 \mathrm{~mm}$. long), longer and more copious hairs, and an elongated inflorescence. The spikelets of $I$. brasiliensis are $4 \mathrm{~mm}$. long. Wright's specimen (3486) is the latter species as shown by the specimen in the herbarium of Grisebach and in that of Sauvalle. This is referred to $I$. caudata by Grisebach $a$ and Sauvalle. $b$

3. SACCHARUM L. Sp. PI. 54. 1753.

1. Saccharum officinarum L. Sp. P1. 54. 1753.

Cienfuegos, Pringle 17; Guanajay, Curtiss 635.

This species (sugar cane) is grown in all tropical countries, and the above specimens are from cultivated plants.

4. ERIANTHUS Michx. Fl. Bor. Amer. 1: 54. 1803.

1. Erianthus saccharoides Michx. Fl. Bor. Amer. 1: 55.1803.

Laguna San Mateo, Pinar del Rio, Wright 3903.

In Sauvalle's Flora Cubana this is called Andropogon alopecuroides L. The latter species, however, has a twisted awn, while in $E$. saccharoides the awn is straight or only slightly bent, not twisted.

$a$ Cat. Pl. Cub. 236. 1866.

b Anal. Acad. Cienc. Habana 8: 288. 1871; Fl. Cub. 202. 
9. ANDROPOGON L. Sp. P1. 1045. 1753.

Racemes numerous in a leafless terminal panicle ............ 7. A. leucopogon. Racemes 1 to 4, solitary or fascicled from spathes.

Racemes solitary.

Spikelets awnless

11. A. spathiflorus.

Spikelets awned.

Outer glume of sterile spikelet conspicuous and bract-

like.................................. 4. A. fastigiatus.

Outer glume not conspicuous.

Plants annual; racemes delicate ............. 2. A. brevifolius.

Plants perennial; racemes not delicate.

Racemes cylindrical, stiff and spike-like.

Sterile pedicel ciliate its entire length;

spikelets 5 to $6 \mathrm{~mm}$. long.......... 10. A. semiberbis.

Sterile pedicel ciliate only at apex; spike-

lets $4 \mathrm{~mm}$. long.................. 12. A.tener.

Racemes zigzag, axis lax and slender; spike-

lets about $3 \mathrm{~mm}$. long.

Racemes conspicuously villous.

Racemes sparsely villous, spikelets about $6 \mathrm{~mm}$ long

Racemes 2 to 4 from each spathe.

Spathes numerous in a large corymb.

Spikelets awnless

1. A. bicornis.

Spikelets long-awned.

6. A. gracilis.

3. A, cubensis.

Spathes scattered or the inflorescence naked and terminal.

Racemes shorter than the spathe..................13. A. virginicus.

Racemes naked, terminal.

Spikelets awned....................... 9. A. nashianus.

Spikelets awnless..................... 8. A. leucostachys.

1. Andropogon bicornis L. Sp..Pl. 1046. 1753.

Arroyo Galiano,.O'Donovan HC 5217; Santiago de las Vegas, Wilson 439; Pinar del Rio, Palmer \& Riley 86; Isle of Pines, Curtiss 294; Retiro, in Savannas, Wright 3902; El Guama, Palmer \& Riley 95; Nueva Gerona, Palmer \& Riley 1125; without locality (1865) Wright 1555; Herradura, Hitchcock in 1906; Cienfuegos, Combs 265 in Gray Herbarium; Madruga, Britton \& Shafer 773 in Herb. '. '. Y.'Böt." Gard.

Wright's 770 from eastern Cuba (1859) is $A$. bicornis as shown by the specimen in Grisebach's herbarium'.

Wright's 1555 as distributed consists in part of Andropogon bicornis and in part of A.glomeratus. The latter is distinguished by the long-awned spikelets.

2. Andropogon brevifolius Sw. Prod. 26. 1788.

Madruga, Curtiss 530; without locality, Wright 1558; Herradura, Hitchcock in 1906.

The Wright specimen in the National Herbarium bears a blank label of 1865 . No. 1558 in the Grisebach Herbarium is from eastern Cuba, 1859, but the plant is A.tener (there has probably been some misplacement of labels here). In the latter herbarium is a specimen from western Cuba, 1863, with the secondary number 925 , upon which Grisebach has marked "=1558." One sheet of Wright 1558 in the Gray Herbarium is $A$. tener, the other $A$. brevifolius, from "Pinales San Diego de Baños, Nov. 16."

3. Andropogon cubensis Hack. Flora 68: 121. 1885.

Without locality, Wright 3898.

This number was not seen by Grisebach, but is listed in Sauvalle's Flora Cubana without specific name. 
4. Andropogon fastigiatus Sw. Prod. 26. 1788.

Dry savannas October 26. Wright 3483.

No. 3483 of Wright, 1865, is accompanied by two supplementary labels, "Savannas, San Cristobal, Nov.," and "Culms few or single, sandy pine woods, Pinar del Rio, Dec." The Grisebach specimen of this is from "Cub. occ. 1863" and bears the secondary number " $921=3483 . " \quad$ No. 3485 [error for 3483?] in the Gray Herbarium was collected by Wright in 1860-64 in "sandy pine woods, Asiento Viejo, Los Remales, Dec. 2."

5. Andropogon glomeratus (Walt.) B.S.P. Prel. Cat. N. Y. 67. 1888.

Cinna glomerata Walt. Fl. Car. 59. 1788.

Andropogon macrourum Michx. Fl. Bor. Amer. 1: 56. 1803.

Hanabana, Wright 1555; Isle of Pines, Curtiss 294, Taylor 18 in Herb. N. Y. Bot. Gard.; Batabano, Shafer 224; Habana, Schott 103; Guanabacoa, Leon 565, 572; Santiago de las Vegas, Wilson 2207 in Herb. N. Y. Bot. Gard.; Matanzas, Britton \& Wilson 83, 94 in Herb. N. Y. Bot. Gard.; Maraguana, Wilson 7553 in Herb. N. Y. Bot. Gard.

Wright's 1555 in the National Herbarium is A. bicornis. The specimen in the Grisebach Herbarium with this number is A. glomeratus, but it is from eastern Cuba, collected in 1859. In the Gray Herbarium one sheet of Wright 1555 (1859) is A. glomeratus, another (1865) is $A$. bicornis.

6. Andropogon gracilis Spreng. Syst. 1:284. 1825.

Schizachyrium gracile Nash in Small, FI. Southeast. U. S. 60. 1903.

Wright 3484 [3480 in Sauv. Fl. Cub.] without data. Isle of Pines, Curtiss 380, Taylor 17; Buena Vista, Shafer in 1903; Herradura, Baker \& Dimmock HC 4829, Tracy 9067; Candelaria, Earle \& Wilson HC 1637; Calvario, Leon 562.

Wright's 3484 in the Grisebach Herbarium has a blank label of $1860-64$, but is without other data. The Wright specimen of this species in the National Herbarium has a blank label of 1865, with the number 204 and also a tag in Wright's handwriting, "Pine woods, Cagalbana, Apr. 17." Wright's 1557, in the Grisebach Herbarium, "Cub. or." in 1859, is also A. gracilis. This species was described under Andropogon scoparius Michx. in Sagra's History of Cuba.a

7. Andropogon leucopogon Nees, Linnaea 19:694. 1847.

Isle of Pines, Curtiss 382; Wright 1556 in Grisebach Herbarium.

In the Grisebach Herbarium and in the Gray Herbarium Wright 1556 is labeled as collected in eastern Cuba in 1859. Curtiss's specimen was distributed under an unpublished name. $\operatorname{Lean} 893$

8. Andropogon leucostachys H.B.K. Nov. Gen. \& Sp. 1:187. 1816. Andropogon domingensis Roem. \& Schult. Syst. 2:809. 1817.

Isle of Pines, Curtiss 314, Taylor 16; Nadruga, Baker HC 3458; Herradura, Earle HC 3111, Tracy 9046, Consolacion del Sur, Palmer \& Riley 480; bushy savannas, Hanabana, May 17, Wright 3900-7

-Grisebach's specimen of this has an 1865 label with the secondary number 202. = -

9. Andropogon nasnianus sp. nov.

Culms solitary or few in a cluster, simple, slender, erect, glabrous, 30 to $45 \mathrm{~cm}$. high, nodes glabrous; sheaths glabrous or sparsely pilose toward the summit, much shorter than the elongated internodes, broader at the summit than the base of the

$a$ Rich. in Sagra, Hist. Cub. 11:320. 1850. The types of the grasses described by Richard in this work are at the Museum d'Histoire Naturelle at Paris. The types of Panicum were examined by the writer in the spring of 1907. Fragments from the types of five other species were later sent to the National Herbarium through the kindness of Director Le Comte.

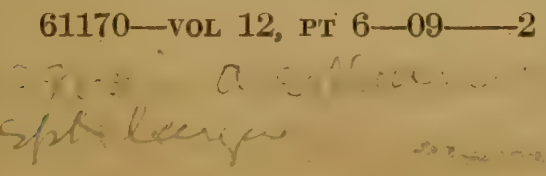


blade thus forming more or less of a shoulder; blades narrow, folded, appressed, glabrous, 1 to $4 \mathrm{~cm}$. long, $1 \mathrm{~mm}$. wide, the basal as much as $10 \mathrm{~cm}$. long, the uppermost reduced to points 1 to $3 \mathrm{~mm}$. long; inflorescence at the summit of the naked culm, the peduncle long-exserted from the uppermost sheath; racemes in pairs 3 to $4 \mathrm{~cm}$. long, very villous with tawny hairs 5 to $7 \mathrm{~mm}$. long from the rachis and the sterile pedicel; sessile spikelets 3 to $4 \mathrm{~mm}$. long, as long as or slightly longer than the internodes of the rachis; first glume nerveless between the scabrous keels, second glume slightly shorter than the first, sterile and fertile lemmas hyaline, slightly shorter than the second glume, the fertile lemma bearing an awn which extends 10 to $15 \mathrm{~mm}$. beyond the spikelet; stamen 1; sterile pedicel $3 \mathrm{~mm}$. long, bearing an involute scale 1 to $2 \mathrm{~mm}$. long.

Type, Cuba, Wright 3899, no. 35320 in U. S. National Herbarium.

Sandy pine woods, western Cuba. In addition to the type this species is represented by: Herradura, Hitchcock in 1906, Tracy 9069.

The specimen of Wright 3899 in the Sauvalle Herbarium is labeled "Sandy pine woods, Pinar del Rio. Sept. Culms few or single, scattering."

This species is named for Mr. George V. Nash, who, while studying the species of Andropogon in the National Herbarium, suggested that the above-mentioned specimens did not belong to $A$. leucostachys, to which they had been referred. The species is allied to A. leucostachys H. B. K. and A. subtenuis Nash.

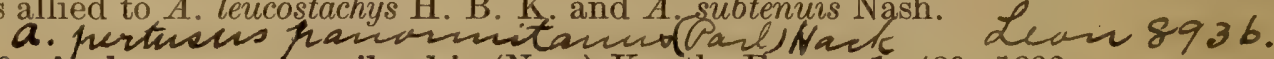

10. Andropogon semibert is (Nees) Kunth, Enum. 1:489. 1833.

Schizachyrium semiberbe Nees, Agrost. Bras. 336. 1829.

Wright 389, (in 1865). Hubanc, Leon 1956, 1529.

11. Andropogon spathiflorus (Nees) Kunth, Enum. 1: 496.1833.

Hypogynium spathiflorum Nees, Agrost. Bras. 366. 1829.

Anatherum spathiflorum Griseb. Cat. P1. Cub. 236. 1866.

Wright 3481; Herradura, Baker \& Dimmock HC 4814; Isle of Pines, Curtiss 460, Taylor 23.

The Sauvalle specimen has two labels, "Savannas Dayaniguas Sept." and "Pinales, Dayaniguas Sept." Another sheet has a blank label, "3480 Anatherum inerme Gris." In the Grisebach Herbarium are two sheets of this, one marked 3481 on an 1860-64 label, and another marked " $899=3481$, Cub. occ. 1863." Thespecimen in the National Herbarium with the number 3481 has this on an 1865 label.

In the Grisebach Herbarium there are two other sheets of this species, marked Anatherum inerme Griseb., "3480 Cuba 1860-64," and "898=3480, Cub. occ. 1863." I have not seen the type of Anatherum inerme (Steud.) Griseb. ${ }^{a}$. (Andropogon inermis Steud.) ${ }^{b}$, which is from Venezuela, but Hackel placesit under Andropogon spathiflorus as variety inermis.c I do not see that Wright's 3480 differs from 3481 . Nees's type at Munich is the same. One sheet of this species in the Gray Herbarium is marked " $3480=3481$ " and is from "pinales (wet), Los Almacigos, July 29;" another from the same locality is marked " $3481=3480$."

12. Andropogon tener (Nees) Kunth, Rev. Gram. 2: 565. 1832.

Schizachyrium tenerum Nees, Agrost. Bras. 336. 1829.

Wright 3482; Herradura, Tracy 9065.

Grisebach's specimen is labeled "Cub. occ. 1863 " and is numbered " $914=3482$. ." The Wright specimen in the National Herbarium has an 1865 label. Wright's 3482 in the Gray Herbarium is from "savannas, Almacigos, July 25." One sheet of Wright's 1558 in the Gray Herbarium is this species, the other is A. brevifolius.

13. Andropogon virginicus L. Sp. Pl. 1046. 1753.

Wright 3901; Santiago de las Vegas, Baker \& Wilson HC 599; Guanabacoa, Leon 193. The Sauvalle specimen has no data. The Wright specimen in the National Herbarium bears an 1865 label.

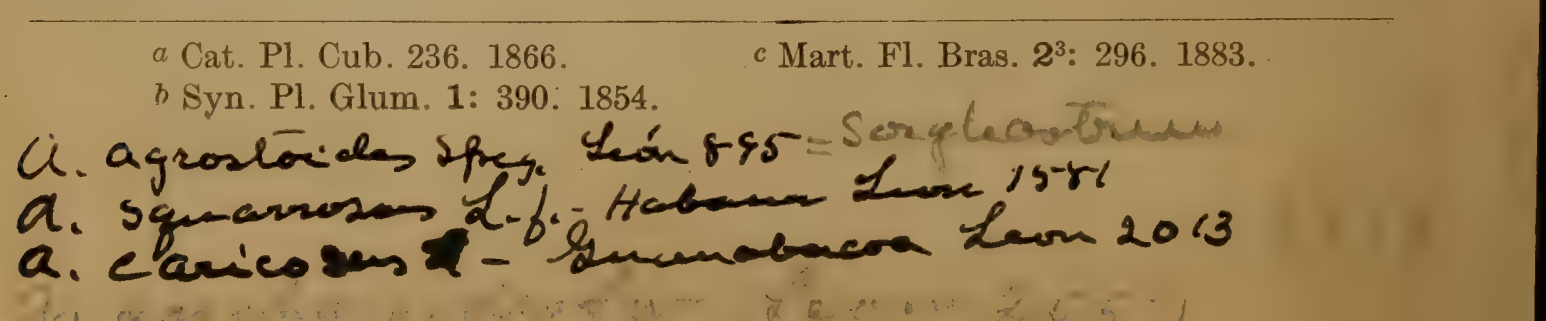


10. HolcUs L. Sp. P1. 1047. 1753, $a$

1. Holcus halepensis L. Sp. P1. 2: 1047. 1753.

Andropogon halepensis Brot. Fl. Lusit. 1: 89. 1804.

Sorghum halepense Pers. Syn. 1: 101. 1805.

Habana, Curtiss 561, Leon 271; Santiago de las Vegas, Baker HC 503, Hitchcock in 1906; Guanajay, Palmer \& Riley 664, 815; without data, Wright 3488; Vedado, Leon 424.

Wright's 3488 in the Grisebach Herbarium bears the data, "Cub. or. 1860-64, fields near Matanzas."

\section{SORGHASTRUM Nash in Britton, Man. 71. 1901.b}

Awn 10 to $15 \mathrm{~mm}$. long................................. S. francavillanum. Awn not over $2 \mathrm{~mm}$. long .............................. S. Setosum.

1. Sorghastrum francavillanum (Fourn.). - Sliproides

Andropogon francavillanus Fourn. Mex. Pl. 2: 56. 1886.

Pinar del Rio, Wright 3896; Herradura, Baker HC 2179.

The Sauvalle specimen has two labels, "Sandy piile woods Oct.,". and "Low savannas and pinales Sept." The Wright specimen in the National Herbarium has an 1865 label. This species has a loose panicle, with slender branches; the spikelets are about. $5 \mathrm{~mm}$. long, light brown, sparsely pilose on the lower half; the pedicel of the upper spikelet about $4 \mathrm{~mm}$. long, awn 10 to $15 \mathrm{~mm}$. long, once, or more or less twice, geniculate; blades long and folded or convolute, about $3 \mathrm{~mm}$. wide. I have not seen Fournier's type of this, but his description applies to the Cuban plant.

2. Sorghastrum setosum (Griseb.).

Andropogon setosus Griseb. Cat. Pl. Cub. 235. 1866.

Wright 3897.

The specimen in Grisebach's herbarium, which is the type, has a blank label of 1865 and bears the secondary number 208. The Sauvalle Herbarium contains a specimen accompanied by a similar label with no. "208" and a second of the same kind, with no. "3897" and also a label with habitat, "Bushy savannas, Hanabana, June 1." This is a duplicate type. Wright's 3897 in the Gray Herbarium is from "Bushy savannas, Hanabana, June 6."

The inflorescence is comparatively dense; the spikelets smaller than in the preceding, only about 3 to $3.5 \mathrm{~mm}$. long, long-pilose all over; pedicel of the upper spikelet 2 to $3 \mathrm{~mm}$. long; awn none or short and exserted 1 to $2 \mathrm{~mm}$; blades flat, $5 \mathrm{~mm}$. wide, about $15 \mathrm{~cm}$. long.

\section{RHAPHIS Lour. Fl. Cochinch. 552. 1790.}

1. Rhaphis pauciflora (Chapm.) Nash in Small, Fl. Southeast. U. S. 67. 1903.

Sorghum pauciflorum Chapm. Bot. Gaz. 3: 20. 1878.

Sandy pine woods, Pinar del Rio, Wright 3895; Isle of Pines, Taylor 46.

This is listed in Sauvalle's Flora ('ubana as "Andropogon (Chrysopogon) urightii Munro," but is without description. Under this are mentioned nos. 293 and 263.

a Holcus sorghum L. must be considered the type of the genus Holcus since it is the most important economic species of the genus and further, since, in the fifth edition of his Genera Plantarum, Linnæus refers to the genus Sorgum Mich [eli] as a synonym of Holcus.

$b$ Poranthera Raf. (Ser. Bull. Bot. 1: 221. 1830) has for its type Andropogon nutans L., but the name was previously used for a genus of Fuphorbiaceae (Rudge, Trans. Linn. Soc. 10: 302. 1811). The type species of Sorghastrum Nash is Andropogon avenaceum Michx., which is the same as $A$. nutans $\mathrm{L}$. 
The latter I have not seen. Wright's 293 is in the Gray Herbarium, labeled as above, with the herbarium name of Munro.

13. Heteropogon Peis. Syn. 2: 533. 1807.

1. Heteropogon contortus (L.) Roem. \& Schult. Syst. 2: 836. 1817.

Andropogon contortus L. Sp. P1. 2: 1045. 1753.

Andropogon secundus Willd.; Nees, Agrost. Bras. 364. 1829, in note.

Eastern Cuba, Wright 1559.

This specimen is in the Grisebach Herbarium and is listed in Grisebach's catalogue of Cuba plants as Andropogon (Heteropogon) secundus. (Heteropogon secundus Presl is a species of Trachypogon.) Sauvalle lists no. 1559 as Andropogon contortus, but there is no specimen of this number in the Sauvalle Herbarium. One is found, however, in the Gray Herbarium.

14. NAZIA Adans. Fam. P1. 2: 31, 581. 1763.

1. Nazia aliena (Spreng.) Scribn. U. S. Dept. Agr. Div. Agrost. Bull. 17: 28. 1899. Lappago aliena Spreng. Neue Entd. 3: 15. 1822.

Wright 3489, without data.

The Grisebach specimen was collected "1860-64." This is listed in Sauvalle's Flora Cubana as Lappago racemosa.

15. ANTHEPHORA Schreb. Beschr. Gräs. 2: 105. pl. 44. 1810.

1. Anthephora hermaphrodita (L.) Kuntze, Rev. Gen. PI. 2: 759.1891.

Tripsacum hermaphroditum L. Syst. ed. 10, 2: 1261. 1759.

Anthephora elegans Schreb. Beschr. Gräs. 2: 105.1810.

In sand along the shore La Palma Sola, Aug. 7, Wright 3890; Santiago de las Vegas, Van Hermann HC 2694, Hitchcock in 1906; Herradura, Baker HC 2691; La Magdalena, Baker HC 3634; Cienfuegos, Combs 257 in Gray Herbarium.

This is listed in Sauvalle's Flora Cubana as 3870. The Sauvalle specimen is marked 3890, as is the specimen in the National Herbarium. The former specimen is accompanied by a second label with the secondary number 308, which is the only number with the Grisebach specimen.

16. ARUNDINELLA Raddi; Agrost. Bras. 37. pl. 1.f. 3. 1823.

Awn bent, tightly twisted below......................... martinicensis.

Awn bent, but not tightly twisted.

Blades flat, over $1 \mathrm{~cm}$. wide; panicle dense, $30 \mathrm{~cm}$. or more long........................................... A. deppeana.

Blades more or less folded, less than $1 \mathrm{~cm}$. wide; panicle

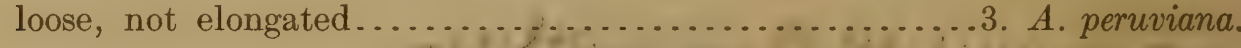

1. Arundinella deppeana Nees, Bonplandia 3: 84. 1855.

Arundinella phragmitoides Griseb. Cat. Pl. Cub. 234. 1866.

Wright 3479; Madruga, Curtiss 662, Britton \& Shafer 647 in Herb. N. Y. Bot. Gard.; Pinar del Rio, Palmer \& Riley 70; Shafer 304 in Herb. N. Y. Bot. Gard.; without locality, Otto 268.

Grisebach's specimen is from western Cuba in 1863 and is numbered " $933=3479 . "$ I have not seen Nees's type, "Seemann n. 428, Panama." Nees describes the awn as 6 lines long, strongly geniculate in the middle and not twisted. This can only apply to $A$. phragmitoides and to $A$. peruviana. Nees further states that the leaves are smooth and one-half inch wide, and the panicle over a foot long and 4 inches thick. This applies best to A. phragmitoides, though the blades are usually more or less pilose. Specimens in the National Herbarium are as follows: Mexico: Lieb- 
mann 629, 630; Langlassé 608; C. T. Smith 1892; Botteri 730, 731, 734; Palmer 1264, 1920. Guatemala: Heyde \& Lux 3907; Maxon \& Hay 3526; Rock in 1887; World's Fair Commission in 1893. Salvador: Renson 207. Costa Rica: Tonduz 9211.

2. Arundinella martinicensis Trin. Gram. Pan. 62. 1826.

Arundinella pallida Nees, Agrost. Bras. 465. 1829.

Thysanachne scoparia Presl, Rel. Haenk. 253. 1830.

Wright 3478.

The Grisebach specimen is from eastern Cuba in 1950 and numbered " $113=34$ i8." Wright's 3478 in the Gray Herbarium is from San Juan de Buenavista, Nov. 21. These were compared with the type of Nees at Munich and that of Trinius at St. Petersburg (from Martinique, Sieber 262). This species has an elongated dense panicle, more or less folded blades, the bent awn twisted below. It ranges from Cuba and Mexico to Brazil, and is represented in the National Herbarium by the following: Porto Rico: Heller 934, 4355, 6256; Sintenis 361, 5797; Barrett 101. Santo Domingo: Wright, Parry \& Brummel 626. Jamaica: Eggers 3514. Mexico: Palmer 434. Costa Rica: Pittier 11005; - Tonduz 3672. Brazil: Glaziou 17433; Regnell 1414 (III).

Thysanachne scoparia Presl was published in the Symbolae Botanicae, the title page date of which is 1832 and which, hence, is later than the Reliquiae Haenkeanae. But the part containing the above species must have been published earlier, for in the latter work $a$ is cited "T. scoparia. Presl de thysanachne, 1829. cum icone." There appears to be no such work by Presl except the portion of the Symbolae (pages 11 and 12 and pl. 6) where Thysanachne and T. scoparia are described as if they were there originally published. The species is based on Sieber 264 from Martinique. Presl's type from Mexico was examined at Prague.

Pilger $b$ refexs the Porto Rico species to A. hispida (Willd.) Kuntze (Andropogon hispidus Willd.), to which he also refers $A$. brasiliensis Raddi. I have not seen the type of either of the last two species, but in Trinius's herbarium is the type of Goldbachia mikani Trin., which is included by Pilger in the list of synonyrus of $A$. hispida. This I consider distinct from A. pallida, as did Nees, $c$ and it is that I take to be A. brasiliensis Raddi. This is also the A. brasiliensis of Hackel in Martius's Flora Brasiliensis, as indicated by plate 38 and by specimens so named received from Professor Hackel. The spikelets are smaller and the awn shorter, sometimes scarcely exserted. This species is represented in the National Herbarium by the following: Mexico: Liebmann 622, 635. Colombia: Pittier 1527. British Guiana: Mount Roraima Exped. 254. Brazil: Glaziou 17921, 20567 a; Henschen in 1868, Dusén 3875. Uruguay: Arechavaleta.

3. Arundinella peruviana (Presl) Steud. Syn. Pl. Glum. 1: 115. 1854.

Thysanachne peruviana Presl, Rel. Haenk. 253.- 1830.

Arundinella cubensis Griseb. Mem. Amer. Acad. n. ser. 8: 533. 1862.d

Arundinella crinita Trin. Linnaea 10: 299. 1836.

Wright 1552.

Sheaths and blades pilose, the latter narrow and more or less folded, usually less than $0.5 \mathrm{~cm}$. wide; panicle rather loose, not elongated as in A. martinicensis; awn slender and bowed back like a shepherd's crook, but not twisted. The type of A. cubensis from eastern Cuba, no. 1552 in 1859, is in the Grisebach Herbarium. Another specimen also from eastern Cuba, 1860, is numbered " $115=1552$."

The types above cited, namely, those of Presl at Prague, Grisebach at Göttingen, and Trinius at St. Petersburg, agree with each other and are well characterized by the shape of the awn. Additional specimens in the National Herbarium are as follows: Mexico: Liebmann 621, 625, 632, 634; Bourgeau 1660, 2223; Palmer 12, 526,

$a$ Rel. Haenk. 253.

$b$ In Urb. Symb. Antill. 4: 80. 1903. c Agrost. Bras. 465. 1829.

d Pl. Wright. 2. 
652; Pringle 3133. Guatemala: Cook \& Griggs 691. Costa Rica: Pittier 2407, 11246; Biolley 7469; Tonduz 4867. Brazil: Commis. Geogr. S. Paulo 2800.

In the collection of Haenke at the herbarium of the German University at Prague there are, under Thysanachne peruviana, two specimens. One is accompanied by the label, "Peruan. mont. guanoc. Hanke." This specimen corresponds to Presl's description of this species and agrees with a duplicate in the Bernhardi Herbarium at the Missouri Botanical Garden figured by Scribner.a The other specimen is A. martinicensis Trin.

17. TRISCENIA Griseb. Mem. Amer. Acad. n. ser. 8: 534. 1862.

1. Trisconia ovina Griseb. Mem. Amer. Acad. n. ser. 8: .534. 1862.

Banks of creeks, May 28, Wright 756.

The Grisebach specimen is from eastern Cuba in 1859, no. 756.

Grisebach $b$ cites this number also under Isachne leersioides. This appears to be an error, as. in Grisebach's herbarium this number occurs only with Triscenia ovina. Wright's 756 in the Gray Herbarium is from "banks of Pinal Creek in small dense tufts, Monte Verde, Aug. 10, 1859."

18. REIMAROCHLOA gen. nov.

Spikelets lanceolate, acuminate, solitary, subsessile along one side of a flattened narrow rachis (the back of the fertile lemma turned toward it), forming few to several slender racemes, approximate at the summit of the culm, spreading or reflexed at maturity; glumes obsolete except in the terminal spikelet in which one glume is frequently present; sterile lemma exceeding the fruit; fertile lemma scarcely indurated, faintly nerved, long-acuminate, inrolled at the base only, the palea of similar texture, free nearly half its length.

Perennials of the tropics and'subtropics of the Western Hemisphere.

The genus Reimaria as established by Flügge on the single differentiating character "uniglumis," included three species, the first two of which, $R$. candida and $R$. elegans, differ from Paspalum only in having spikelets without glumes, a character which is unreliable in this group of Paniceae. The third species, $R$. acuta, together with those added to Reimaria by later authors, constitutes a distinct genus distinguished by the characters in the diagnosis above. Considering that Flügge's three species are not congeneric, but that the first two on the one hand and the third on the other must be separated, it is necessary that the name Reimaria go with the larger group. $c$ Reimaria then becomes a synonym of Paspalum, or if the glumeless species, $P$. candidum H. B. K., P. pulchellum H. B. K., P. elongatum Griseb., etc., be considered generically distinct, the name would apply to this group. For $R$. acuta and its allied species the above name is proposed with Reimaria acuta Flügge as the type: Reimarochloa acuta (Flügge). Paspalum vaginatum $\mathrm{Sw}$. and $P$. distichum L. (in which both glumes are occasionally present) in habit and texture of the acute fruits show a closer affinity to this genus than do the glumeless species mentioned above.

Spikelets about $2 \mathrm{~mm}$. long............................. brasitiensis.

Spikelets about $5 \mathrm{~mm}$. long .................................... oligostachya.

1. Reimarochloa brasiliensis (Spreng.).

Agrostis brasitiensis Spreng. Nov. Prov. Hal. 45. 1819.

Reimaria brasiliensis Schlecht. Bot. Zeit. 10: 17. 1852.

Panicum oxyanthum Steud. Syn. Pl. Glum. 1: 41. 1854.

Wright 3437; Isle of Pines, Curtiss 497.

Grisebach's specimen of this number is from "savannas, Hanabana, May 22." Another specimen in his herbarium from "low wet ground around ponds, Hanabana"

a Rep. Mo. Bot. Gard. 10: pl. 6. 1899.

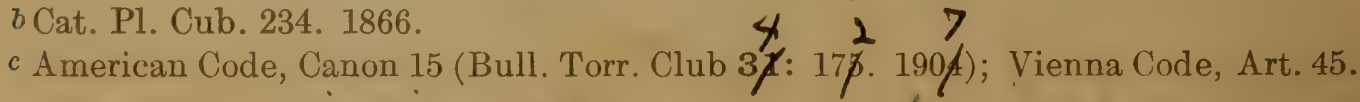


bears the secondary number 206. The specimen in the Gray Herbarium is labeled, "Wet savannas, Candelaria, June 5, 1860-64." The type of Panicum oxyanthum Steud. labeled "Ins. St. Domingo, Legit Poiteau 1802 cf. hrbr Delessert 54" in the museum at Paris, is a small specimen of this species; that in the Delessert Herbarium is a good specimen.

\section{Reimarochloa oligostachya (Munro).}

Reimaria oligostachya Munro; Benth. Journ. Linn. Soc. 19: 34. 188 .

Wright 3854 in National Herbarium.

This number of Wright's is mentioned in the original description, though the type is Curtiss 3566 from Florida. The specimen in the Sauvalle Herbarium with the number 3854 is Paspalum vaginatum Sw. In the Grisebach Herbarium is a specimen of Reimarochloa oligostachya labeled "Damp ground around ponds Hanabana," 1865, and bearing the secondary number 180. The sheet of Wright 3854 in the Gray Herbarium bears two plants of $R$. oligostachya and one of Paspalum distichum.

\section{PASPALUM L. Syst. ed. 10, 855. 1759.}

Rachis dilated and membranaceous. 9. P. dissectum.

Rachis not dilated and membranaceous.

Racemes terminal and also from the uppermost sheath.

Blades pubescent on both surfaces................ 7. P. debile.

Blades glabrous or nearly so, often ciliate on margins.

Blades ciliate, 4 to $5 \mathrm{~mm}$, wide...............25. $P$. propinquum.

Blades not ciliate.

Blades less than $2 \mathrm{~mm}$. wide; first glume obsolete.............................27. P. rigidifolium.

Blades about $1 \mathrm{~cm}$. wide; first glume present. .23. $P$. pedunculatum. Racemes terminal only.

Racemes in pairs-that is, normally 2 and approximate.

Plants with creeping rootstocks.

Spikelets pubescent on convex surface........10. P. distichum.

Spikelets glabrous on convex surface..........30. P. vaginatum.

Plants without creeping rootstocks.

Both glumes obsolete...................26. P. pulchellum.

First glume only obsolete.

Spikelets circular $1.5 \mathrm{~mm}$. long or less.

Spikelets papillose or nearly glabrous . .22. P. papillosum.

Spikelets villous on the margins ....6. P. conjugatum.

Spikelets lanceolate or elliptical, $2 \mathrm{~mm}$.

long or more.

Spikelets loosely imbricated; spikes

ascending...................... 15. P. lineare.

Spikelets densely imbricated; spikes

spreading.

Spikelets $2 \mathrm{~mm}$. long.............18. P. minus.

Spikelets $3 \mathrm{~mm}$. long............20. P. notatum.

Racemes 1 to several; if 2 , the lower at some distance

below the terminal and the number not constant.

Racemes usually 1, sometimes 2 .

Spikelets transversely wrinkled.

Blades involute, glabrous, elongated, 40

to $60 \mathrm{~cm}$. long...................... 12. P. filiforme.

Blades flat, pubescent, 5 to $15 \mathrm{~cm}$. long...19. $P$. nanum. 
Spikelets not transversely wrinkled.

Pubescence glandular. 5. P. clavuliferum.

Pubescence if present not glandular.

Spikelets about $1 \mathrm{~mm}$. long........29. P. rupestre.

Spikelets 2 to $3 \mathrm{~mm}$. long.

Blades short, $10 \mathrm{~cm}$. long, villous. .28. P. rottboellioides.

Blades elongated 30 to $50 \mathrm{~cm}$.

long, glabrous............... 1. P. alterniflorum.

Racemes more than 1 , often numerous.

First glume present

4. P. ciliiferum

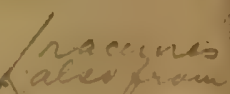

First glume obsolete.

Sterile lemma transversely wrinkled; spikelets brown.

Spikelets obovate................24. P. plicatulum.

Spikelets elliptical................11. P. elatum.

Sterile lemma not transversely wrinkled.

Racemes few, mostly 2 to 4 .

Spikelets flattened...............16. P. lividum.

Spikelets distinctly convex.

Spikelets pubescent.

Pubescence glandular... 2. $P$. arenarium.

- Pubescence not glandu-

lar.

3. P. caespitosum.

Spikelets glabrous.

Spikelets elliptical, about $1 \mathrm{~mm}$. wide ... .13. P. glabrum.

Spikelets circular, about

$2 \mathrm{~mm}$. wide..........14. P hemicryptum)

Racemes numerous.

Spikelets pubescent.

Spikelets hemispherical, slightly exceeding $1 \mathrm{~mm}$.

long....................21. P. paniculatum.

Spikelets flatter, $2 \mathrm{~mm}$. long. - 31. $P$. virgatum. Spikelets glabrous.

Axis long-pilose............ 8. P. densum.

Axis not pilose.

Spikelets elliptical, about $3 \mathrm{~mm}$. long.....32. P. virgatum

Spikelets obovate-circuschreberianum. lar, 2 to $2.5 \mathrm{~mm}$. long.. 17. P. millegrana.

1. Paspalum alterniflorum Rich. in Sagra, Hist. Cub. 11: 299. 1850.

Paspalum dolichophyllum Hack. Inf. Est. Centr. Agron. Cuba 1: 409. 1906.

Wright 3841; Guanabacoa, Leon 117 in part; Habana, Tracy 9105, Baker, Tracy \& Hasselbring in 1907, Leon 564, 585; Marianao, Leon 581. Calabazon, Baker \& O'Donovan HC 4545; Matanzas, Rugel 894 in Herb. N. Y. Bot. Gard.

Grisebach's specimen of this species was collected in 1865 and is accompanied by the data, "In small dense tufts, low savannas, Hanabana, May 19." The sheet bears the secondary number 167. The Sauvalle specimen is accompanied by the two numbers, 3841 and 167, thus connecting the two. In the Grisebach Herbarium is a specimen of this collested in Cuba by Rugel and numbered 753a. Grisebach refers $a$ to "Rug. 894" under this name. Richard's type is at Paris. 
2. Paspalum arenarium Schrad.; Schult. Mant. 2: 172. 1824.

Paspalum simpsoni Nash, Bull. Torr. Club 24: 29. 1897.

Wright 3443 in part, in National Herbarium, and in Gray Herbarium.

Spikelets similar to those of $P$. caespitosum (Wright 3443, in part, in National Herbarium), but glandular-pubescent; leaves mostly near the base of the plant, the blades ciliate on the margins, otherwise glabrous, flat, less than $10 \mathrm{~cm}$. long, 5 to $6 \mathrm{~mm}$. wide; spikes 1 to 3 .

From this $P$. longepedunculatum Le Conte of the southeastern United States differs in having glabrous spikelets and longer, thinner blades. Pittier 1847 from Honduras should also be referred to $P$. arenarium.

3. Paspalum caespitosum Flügge, Mon. Pasp. 161. 1810.

Low wet woods, Pinar del Rio, September, Wright 3443 in part; Cojimar, Baker HC 2899, 2903, Hitchcock in 1906; Triscornia, Tracy 9087, Hitchcock in 1906; Habana, Leon 268; Batabano, Hitchcock in 1906; Matanzas, Britton \& Wilson 11, 236 in Herb. N: Y. Bot. Gard., Britton \& Shafer 63 in Herb. N. Y. Bot. Gard.

Grisebach's specimens of this are labeled " $910=3443$ " from western Cuba, 1863, and " $97=3443$ " from eastern Cuba, 1860. A third " $290=3444$," collected in 1865, agrees with these and not with 3444 [see $P$. clavuliferum. Wright]. There are two sheets of Wright's specimens in the Gray Herbarium numbered 3444, of which one is Paspalum clavuliferum, the other $P$. caespitosum. The latter is labeled "In crevices of rocks in the channel of the river Santa Cruz, Aug. 27." Wright's 3443 in the Gray Herbarium is labeled "Rocky ridges, Holguin-Barajugua, Aug. 21."

4. Paspalum ciliiferum (Nash).

Dimorphostachys ciliifera Nash in Small, Fl. Southeast. U. S. 78. 1903.

Arroyo Naranjo, Leon 587; Matanzas, Britton \& Wilson 148; Madruga, Britton \& Shafer 751, both in Herb. N. Y. Bot. Gard.

5. Paspalum clavuliferum Wright, Anal. Acad. Cienc. Habana 8: 203. 1871; Sauv. Fl. Cub. 195.

Paspalum falcula Doell in Mart. Fl. Bras. $2^{2}: 60,1877$.

Wright 3444 in National Herbarium.

This resembles $P$. papillosum Spreng., but the spikes are usually solitary instead of in pairs and the spikelets obovate instead of orbicular. The type of this is in the Gray Herbarium. The plant in the Sauvalle Herbarium under this number is a different species, as are the two specimens in the Grisebach Herbarium which are said to be " $=3444 "$ " (cf. P. caespitosum and P. rupestre of this list). Salzmann's specimen in Trinius's herbarium from Bahia, labeled Paspalum horticola Salzm., belongs to this species. Salzmann's name was mentioned as a synonym by Steudel under $P$. papillosum.a To $P$. clavuliferum may be referred Pringle 2359 and 11762 from Mexico, and Smith 175 from Colombia.

6. Paspalum conjugatum Berg. Act. Helv. 7 : 129. 1772.

Roadsides, Hanabana, Wright 767; Herradura, Baker HC 2672, Hitchcock in 1906; mountains north of San Diego de los Baños, Palmer \& Riley 541; Santiago de las Vegas, Baker HC 2658, 2659, Wilson 543, 1006, Hitchcock in 1906; Sagua, Britton \& Wilson 265; valley of the St. Augustine, Britton \& Wilson 510, 515; Guajay, Wilson 342; Habana, Wilson 1277, Leon 302. The following are in the herbarium of the New York Botanical Garden: Isle of Pines Curtiss in 1904; Santiago de Cuba, Taylor 146; Baracoa, Underwood \& Earle 1162; Cuba, Rugel 788; Matanzas, Rugel 912.

7. Paspalum debile Michx. Fl. Bor. Amer. 1:44. 1803.

Paspalum villosissimum Nash, Bull. Torr. Club 24:40. 1897.

Herradura, Hitchcock in 1906. 
8. Paspalum densum Poir. in Lam. Encycl. 5: 32.1804.

Dense bunches in ponds, Pinar del Rio, September, Wright 3447.

There is a second specimen of this species in the Sauvalle Herbarium, without locality, erroneously numbered 3462. In the Grisebach Herbarium there are two specimens of this species, one from western Cuba, 1863 , numbered " $866=3447$," the other from "Low wet savannas; Hanabana," 1865.

9. Paspalum dissectum (L.) L. Sp. Pl. ed. 2. 81. 1762.

Panicum dissectum L. Sp. P1. 57. 1753.

Paspalum membranaceum Walt. Fl. Car. 75. 1788.

Low grounds around ponds, procumbent. Hanabana, June 10, Wright 169 [Secondary number].

The same number occurs in the Grisebach Herbarium. A second specimen of this species, from eastern Cuba, 1860, is numbered "98=3440." The specimen in the National Herbarium is numbered 3440 . For a discussion of the type of $P$. dissectum L., see Contr. Nat. Herb. 12: 115. 1908.

10. Paspalum distichum L. Syst. Nat. ed. 10. $2: 855.1759$.

Wright 1546; Habana, Curtiss 764; Santiago de las Vegas, Baker \& Wilson 385; Playa de Marianao, Palmer \& Riley 848; Herradura, Tracy 9056; Isle of Pines, Curtiss in 1904; Matanzas, Britton \& Wilson 67, both in Herb. N. Y. Bot. Gard.

Grisebach's specimen of Wright's 1546 is from eastern Cuba; a second specimen of the same species is from western Cuba, 1863, and is numbered " $911=1546 . "$ In the National Herbarium is a sheet of Wright's with the secondary number 292 which is part this species and part $P$. vaginatum $\mathrm{Sw}$.

11. Paspalum elatum Rich.; Doell in Mart. Fl. Bras. $2^{2}: 78.1877$.

Wright 3843.

This specimen is referred to this species from description only, as no authentic specimens of $P$. elatum have been examined. It is a much taller grass than $P$. plicatulum Michx., which it resembles, with more elliptical and less convex spikelets.

12. Paspalum filiforme Sw. Prod. 22. 1788.

Paspalum swartzianum Flügge, Mon. Pasp. 96. 1810.

Paspalum approximatum Doell in Mart. Fl. Bras. 2²: 82. 1877.

In pastures forming tufts, Retiro, July, Wright 769; Isle of Pines, Curtiss 523, 374, Palmer \& Riley 949; Guanabacoa, Hitchcock in 1906; Rincon, Britton \& Wilson 477 in Herb. N. Y. Bot. Gárd.

Grisebach's specimen of Wright 769 was collected, "1860-1864," "in the edge of woods, Hanabana, May 28." Another of his specimens with the secondary number 165, in 1865 is also from Hanabana, May 23, "in small tufts."

Doell a refers $P$. filiforme $\mathrm{Sw}$. to $P$. caespitosum Flügge. This is not the plant that Swartz describes, as is shown by the original description in the Prodromus and the later amplified description in his Flora. $b$ Swartz describes his plant as having a single spike, ovate spikelets, and filiforme leaves, while $P$. caespitosum has 3 to 5 spikes, oblong-obovate spikelets, and flat blades.

13. Paspalum glabrum Poir. in Lam. Encycl. 5: 30. 1804.

Paspalum bakeri Hack. Inf. Est. Centr. Agron. Cuba 1: 410. 1906.

Habana, Baker 1824; Triscornia, Hitchcock in 1906; without locality, Wright 298; Matanzas, Rugel 869 in Herb. N. Y. Bot. Gard.

In the Grisebach Herbarium is a specimen of $P$. glabrum labeled, "In small tufts, sand banks near the sea, Palma Sola, July 15," 1865, and bearing the secondary number 
298. This species is represented in the Gray Herbarium by Wright 3846, a number which is not mentioned in Sauvalle's Flora Cubana. P. helleri Nasha of Porto Rico differs in having somewhat smaller pubescent spikelets.

14. Paspalum hemicryptum Wright, Anal. Acad. Cienc. Habana 8: 204. 1871; Sauv. Fl. Cub. 196.

Paspalum inops Vasey, Contr. Nat. Herb. 1: 281. 1893.

Low savannas, El Salado, August, Wright 3847.

The type of $P$. inops Vasey (Palmer 592 from Guadalajara, Mexico, in the National Herbarium) agrees with Wright's type in the Gray Herbarium.

15. Paspalum lineare Trin. Gram. Pan. 99. 1826.

Herradura, Baker 3459; Isle of Pines, Curtiss 379.

The type in the Trinius Herbarium is from Brazil, collected by Langsdorff, and is included in the same cover with $P$. angustifolium Nees. Trinius published the latter name on the same page of the work cited, but preceding $P$. lineare on the page. The type is said to be from "Brazil (N. ab Esenb.)." The type specimen is labeled "Paspalum angustifolium N. ab Es. In Brasilia. Mis Auctore." This specimen, however, is not $P$. lineare, but has, as described, smaller spikelets with rugose transversely wrinkled glumes. $P$. angustifolium as described three years later $b$ is the same as $P$. lineare Trin., while variety $\beta$ is $P$. angustifolium as described by Trinius. Consequently $P$. neesii Kunth is a typonym of $P$. angustifolium, since Kunth changes the name of the latter on account of the earlier $P$. angustifolium Le Conte, but the name does not apply to the Cuba plant under consideration.

16. Paspalum lividum Trin.; Schlecht. Linnaea 2: 383. 1854.

Habana, Leon 272, 571, Tracy 9119; Marianao, Leon 588.

This Mexican species is probably a recent introduction into Cuba. The type from Hacienda de la Laguna, Mexico, Schiede, in the Trinius Herbarium, is included in the cover of $P$. denticulatum Trin., but the two specimens are not the same species. The latter has larger spikelets.

17. Paspalum millegrana Schrad.; Schult. Mant. 2: 175. 1824.c

Paspalum underwoodii Nash, Bull. Torr. Club 30: 375. 1903.

Paspalum lentiginosum Presl, err. det. Mez in Urban, Symb. Antill. 4: $82,1903$.

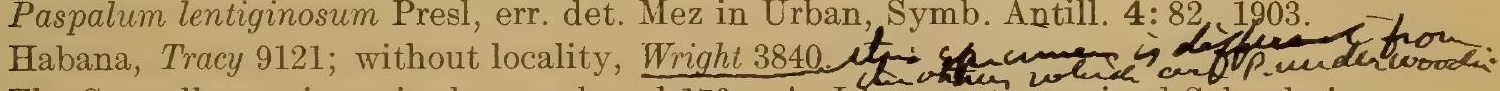

The Sauvalle specimen is also numbered 170. As I have not examined Schrader's type the reference to this is only provisional and based on description. Our specimens are the same as $P$. vulnerans Salzm., from Bahia, as distributed to the National Herbarium. Other specimens in the National Herbarium to be referred here are: Porto Rico: Britton \& Cowell 1449, Heller 4368, Goll 923, Underwood \& Griggs 149. Jamaica: Britton 841 in Herb. N. Y. Bot. Gard.

18. Paspalum minus Fourn. Mex. Pl. 2:6. 1886.

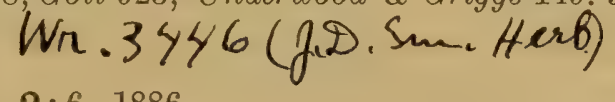

Herradura, Baker \& Abarca HC 4180, Tracy 9093, Hitchcock in 1906; Isle of Pines, Palmer \& Riley, 978; without locality, Wright 3438; Guanabacoa, Leon 117 in part; La Magdalena, Baker 2. The following are in the herbarium of the New York Botanical Garden: Sagua, Britton \& Wilson in 1903; Pinar del Rio, Shafer 477; Isle of Pines, Curtiss in 1904.

These agree with the duplicate type in the National Herbarium (Mexico, Bourgeau 2298). The spikelets are about $2 \mathrm{~mm}$. long. Wright's 3438 in the National Herbarium is partly this and partly $P$. notatum. Grisebach's specimen, from western Cuba, 1863, numbered " $936=3438, "$ is all $P$. minus. The other specimens in this cover

$a$ Bull. Torr. Club 30: 376. 1903.

$b$ Nees, Agrost. Bras. 64. 1829.

c The specific name as used by Schrader is a noun. 
have spikelets $3 \mathrm{~mm}$. long and are $P$. notatum (Jamaica, Alexchder; Trinidad, Sieber 364, labeled P. taphrophyllum Steud.; Antigua, Wullschlaegel). A part of Wright 3438 in the Torrey Herbarium is $P$. minus and a part is $P$. notatum.

19. Paspalum nanum Wright; Griseb. Cat. Pl. Cub. 230. 1866.

Paspalum caudicatum Wright, Anal. Acad. Cienc. Habana 8:205. 1871; Sauv. FI. Cub. 196.

Wright 176 (secondary number); sandy pine woods, Pinar del Rio, October, Wright 3866; Herradura, Hitchcock in 1906; Isle of Pines, Taylor 40, Curtiss in 1904, both in Herb. N. Y. Bot. Gard.

The type of $P$. nanum is Wright 176 in the Grisebach Herbarium, collected in "Bushy savannas, Hanabana, June 1," 1865. This agrees with Wright 3866, the type of $P$. caudicatum, in the Gray Herbarium.

The specimen in the National Herbarium is numbered 3842. The specimen in the Grisebach Herbarium bears the label, "176. Bushy savannas. Hanabana, June 1."

Spikelets sent by Professor Le Comte $a$ from the plant supposed to be the type of Paspalum lindenianum Rich. $b$ show this plant to be the same as $P$. nanum Wright, but this species does not agree with Richard's description in so far as the blades are said to be glaucous and glabrous except the ciliate margins, while in $P$. nanum the blades are pubescent on the surface. Pending a further examination of the type the name $P$. nanum is retained.

20. Paspalum notatum Flügge, Mon. Pasp. 106. 1810.

Herradura, Hitchcock in 1906, Baker HC 2968; Arroyo Galiano, O'Donovan HC 5210; Isle of Pines, Palmer \& Riley 1119; Lomas de Managua, Baker \& Wilson HC 299; Habana, Baker, Tracy \& Hasselbring HC 3097, Tracy 9118; Guines, Leon 117b; Matanzas, Britton \& Wilson 444 in Herb. N. Y. Bot. Gard.

'As stated above, a part of Wright 3438 in the National Herbarium is this species and a part is $P$. minus Fourn. The spikelets of the species as here understood are about $3 \mathrm{~mm}$. long. The type has not been examined. The Baker \& Wilson plant, HC 299, cited above, is larger than the other specimens, with spikelets $4 \mathrm{~mm}$. long, and may be a distinct species. Wright's 3438 in the Gray Herbarium is $P$. notatum; it is labeled "Savannas Chirigote, July 11." This number in the Torrey Herbarium is part $P$. notatum and part $P$. minus.

21. Paspalum paniculatum L. Syst. Nat. ed. 10. 2: 855. 1759.

Savannas, Retiro, Wright 766; San Diego de los Baños, Palmer \& Riley 544; El Guama, Palmer \& Riley 179a; hills near Candelaria, Earle \& Wilson HC 1625; Guines, Leon 579; Cienfuegos, Combs 295 in Gray Herbarium. The following are in the herbarium of the New York Botanical Garden: Matanzas, Britton \& Shafer 576; Santiago de Cuba, Taylor 377; Jaguey, Eggers 5317.

Grisebach's specimen is from eastern Cuba, 1859, no. 766. Nash $c$ applies this name to Panicum fasciculatum Sw., but as has been shown elsewhere $d$ the name Paspalum paniculatum L. should be applied to the Linnæan plant, as heretofore, and not to the Sloane plate cited, through error, by Linnæus.

22. Paspalum papillosum Spreng. Nov. Prov. Hal. 47. 1819.

1. Paspatum pittieri Hack. Oesterr. Bot. Zeitschr. 51: 233. 1901.

Low savannas, Chirigote, October 26, Wright 3844; Herradura, Baker HC 2954, 4185, Hitchcock in 1906.

$a$ See footnote, p. 193.

$b$ Rich. in Sagra, Hist. Cub. 11:299. 1850. The type is Linden 1813.

c Bull. Torr. Club 30: 381. 1903.

$d$ Contr. Nat. Herb. 12: 116. 1908. 
I have not seen the type of this species, but in the Trinius Herbarium there is a specimen labeled "Paspalum papillosum Sprengel, mis. cl. auctor." The Cuban plants agree with this, except that the spikelets are less glandular, the flat surface being quite glabrous. Agreeing with Sprengel's specimen are two in the Trinius Herbarium, one collected by Salzmann in Bahia labeled "Paspalum horticola maritima Salzm." and another by Riedel at Bahia in 1831. Tonduz's 4474 from Costa Rica belongs here. Wright's 3444 in the Torrey Herbarium is $P$. papillosum.

23. Paspalum pedunculatum Poir. Encycl. Suppl. 4: 315. 1816.

Paspalum decumbens Sw. Prod. 22. 1788, not Rottb. 1778.

Panicum decumbens Roem. \& Schult. Syst. 2:429. 1817.

Paspalum vaginiflorum Steud. Syn. P1. Glum. 1: 19. 1854.

Dimorphostachys pedunculata Fourn. Mex. Pl. 2:15. 1886.

Banks of Rio San Sebastian, Pinar del Rio, December, Wright 3851; Isle of Pines, Curtiss 327 .

A second Wright label reads, "Damp woods, Rangel, Dec."

Steudel's type, from "Guiana, Lenormand" is in the museum at Paris.

24. Paspalum plicatulum Michx. Fl. Bor. Amer. 1: 45.1803.

Savannas, Retiro, Wright 768; in small tufts, pinales, Pinar del Rio, Wright 3839; Magay, Baker \& Wilson HC 354; Santiago de las Vegas, Wilson 420, 421, 425, Baker 2056, 3112, 3113, 3454, Baker \& Witson, 545, 596, Hitchcock in 1906; La Magdalena, Baker 5, 7; Habana, Tracy, 9117; Herradura, Tracy 9051, 9052, Hitchcock in 1906; Isle of Pines, Palmer \& Riley 947, Taylor 38; Cienfuegos, Combs 262 in Gray Herbarium. The following are in the herbarium of the New York Botanical Garden: Isle of Pines, Curtiss in 1904; Alto Cedro, Underwood \& Earle 1621; Matanzas, Britton \& Wilson 429; Sagua, Britton \& Wilson 280, 285, 337; La Soledad, Eggers, 5405.

The Grisebach specimen, from "edge of savannas, Hanabana, May 19," 1856, bears the secondary number 166 . Wright's 768 in the Gray Herbarium is labeled, "Savannas, Chirigote, July 11.""

25. Paspalum propinquum Nash, Bull. N. Y. Bot. Gard. 1: 291. 1899. Wright 3845.

26. Paspalum pulchellum Kunth, Mem. Mus. Hist. Nat. 2: 68. 1815.

Reimaria elegans Flügge, Mon. Pasp. 216. 1810, not Paspalum elegans Kunth, Enum. 1:59. 1833.

- Wright 3439; Herradura, Hitchcock in 1906; Isle of Pines, Curtiss in 1904 in Herb. N. Y. Bot. Gard.

The specimen in the National Herbarium bears the secondary number 171. One of the Grisebach specimens is from western Cuba in 1863, and is numbered " $915=3439$;" the other bears the secondary number 171 and is labeled "Bushy savannas, Hanabana, May 24, 1865." One sheet of this in the Torrey Herbarium is numbered 3839.

27. Paspalum rigidifolium Nash, Bull. N. Y. Bot. Gard. 1: 292. 1899.

\section{Wright 3442.}

The Grisebach specimen of this species, collected in western Cuba in 1863, bears the number " $905=3442$." Wright's 3442 in the Gray Herbarium is labeled "Savannas, Chirigote, July 11."

28. Paspalum rottboellioides Wright, Anal. Acad. Cienc. Habana 8: 204. 1871; Sauv. Fl. Cub. 195.

Wright 3864; Isle of Pines, Curtiss 375, Taylor 41; Herradura, Baker \& Dimmock $\mathrm{HC} 4813$.

The type of this species is Wright 3864 in the Gray Herbarium. 
29. Paspalum rupestre Trin. Linnaea 10: 293. 1836.

Wright 3444, 3445; near Habana, Hitchcock in 1906; Leon 286. 1997, 1996,1527

The Grisebach specimen is from eastern Cuba, 1860, numbered " $109=3445$," and is labeled, "Paspalum lindenianum Rich. (Megaphyllum Steud.)," under whirh name it is listed in.Grisebach's Catalogue of Cuban Plants. a A second specimen is from western Cuba, 1863, and is numbered "939=3445." A third specimen collecterl in 1863 and numbered " $943=3444$," is included by Grisebach in his cover of $P$. caespitosum. Wright's 3445 in the Gray Herbarium is labeled "Pinales near Baracoa, June 15."

30. Paspalum vaginatum Sw. Prod. 21. 1788.

Digitaria foliosa Lag. Gen. \& Sp. Nov. 4. 1816.

Hanabana, Doctor Robbins, Wright 3854; Habana, Curtiss 751; Batabano, Baker HC $2294,1863$.

The characters which separate this from $P$. distichum L., the glabrous spikelets and more or less suppressed midnerve of the glume, may prove to be inconstant. Grisebach's specimen from western Cuba, 1863, numbered 947, is this species. A part of Wright 1546 (1546a) in the Torrey Herbarium has glabrous spikelets, and consequently would be referred to $P$. vaginatum.

Lagasca's type, labeled "Digitaria foliosa sp. n. ex Havana, Boldo iter," is in the herbarium of the Botanical Garden at Madrid.

31. Paspalum virgatum L. Syst. Nat. ed. 10. 2: 855. 1759.

Paspalum leucocheilum Wright, Anal. Acad. Cienc. Habana 8:203. 1871; Sauv. FI. Cub. 194.

Isle of Pines, Curtiss 501, Taylor 42, Palmer \& Riley 1057; without locality, Wright 3446; La Magdalena, Baker HC 3626, Britton \& Shafer 243 in Herb. N. Y. Bot. Gard.; Santiago de las Vegas, Baker HC 544, 595; Las Acostas, Baker HC 5242, 5246; Batabano. Baker HC 3967; Arroyo Galiano, Baker HC 5211; Habana, Tracy, Baker \& Hasselbring HC 3085, Tracy 9120, 9122, 9123, 9124; Guanabacoa, Leon 195; Herradura, Tracy 9127, Hitchcock in 1906; San Diego de los Baños, Palmer \& Riley 628; Guines, Leon 578, Pinar del Rio, Shafer 479 in Herb. N. Y. Bot. Gard.; Matanzas, Britton \& Wilson 155, 455 in Herb. N. Y. Bot. Gard.

Grisebach's specimen is numbered 302 (labeled $\beta$ stramineum), while the specimen in the Sauvalle Herbarium bears this number in addition to no. 3446. The type specimen of $P$. leucocheilum Wright is in the Gray Herbarium. The spikelets are somewhat smaller than normal ( $2 \mathrm{~mm}$. long), and the inflorescence consists of a single spike partially concealed in the uppermost sheath. The spikelets have the shape and pubescence of $P$. virgatum.

31a. Paspalum virgatum schreberianum Flügge, Mon. Pasp. 190. 1810.

Guanajay, Palmer \& Riley 813 in part; Herradura, Hitchcock in 1906; Batabano, Hitchcock in 1906; Habana, Tracy. 9125, 9126; Wright 3446 in Gray Herbarium; Rugel 898 in Gray Herbarium; Isle of Pines, Curtiss in 1904 in Herb. N. Y. Bot. Gard. Cienfuegos, Combs 262 in Herb. N. Y. Bot. Gard.

This differs from P.virgatum in its scarcely pilose rachis and oblong-obovate, acute, glabrous spikelets. It appears to be a distinct species, but as the type has not been examined, our plants are referred as above, rather than separated under a new name. This form appears to be included in $P$. virgatum glabriusculum by Doell in Martius's Flora Brasiliensis. $b$ Wright's 3446 in Gray Herbarium is labeled, "In large tufts on sand bars of the Baracoa near N. Sophie, Sept. 11."

32. Paspalum sp.

Wright 3848.

This specimen in the Sauvalle Herbarium is too fragmentary to identify. It appears to belong to none of the species enumerated in the list. It is listed in Sau- 
valle's Flora Cubana as "P. swartzianum Flügg?," but it is not that species as here understood. The specimen in the Gray Herbarium is less fragmentary. The blades are long and narrow, 30 or $40 \mathrm{~cm}$. long and less than $1 \mathrm{~mm}$. wide; terminal spike single; spikelets glabrous, $1.5 \mathrm{~mm}$. long. A part of Wright 3444 in the Gray Herbarium appears to be this species. nostch hum

\section{Axonopus compressus (Sw.) Beauv. Agrost. 12. 1812.}

\section{Milium compressum Sw. Prod. 24. 1788.}

Paspalum compressum Rasp. Ann. Sci. Nat: I. 5: 301. 1825.

Wet places in roads and elsewhere Zarabanda, May 21, Wright 3849, Wright 3850 , Wright 763 in Gray Herbarium; Isle of Pines, Curtiss 306, 511; Habana, Curtiss 606, Leon 298; Herradura, Hitchcock in 1906, Tracy 9092; San Antonio, Baker HC 2946, Hitchcock in 1906; Santiago de las Vegas, Hitchcock in 1906; Managua, Baker \& Wilson 314 in Herb. N. Y. Bot. Gard.; Matanzas, Britton \& Wilson 104 in Herb. N. Y. Bot. Gard.

In the Grisebach Herbarium are two specimens of this species, one of 1865 labeled, "Roadside, Hanabana, May 18," and bearing the secondary number 168, and one of no. 765, 1860-64. The Sauvalle specimen of Wright 3850 has two labels, with localities El Salado and Retiro. This number has narrower blades and larger spikelets, about $3 \mathrm{~mm}$. long. This may be Paspalum tristachyon Lam., a the type of which I have not seen. The sheet of Wright 3849 in the Gray Herbarium bears also a specimen of Syntherisma digitata.

\section{LEPTOCORYPHIUM Nees, Agrost. Bras. 83. 1829.}

1. Leptocoryphium lanatum (H. B. K.) Nees, Agrost. Bras. 83. 1829.

Paspalum lanatum H. B. K. Nov. Gen. \& Sp. 1:94. 1816.

Wright 3429; Isle of Pines, Palmer \& Riley 440, 972, Curtiss 393; La Magdalena, Baker HC 4555; Herradura, Hitchcock in 1906, Tracy 9048, 9071. The following are in the herbarium of the New York Botanical Garden: Santa Clara, Britton \& Wilson 335; Pinar del Rio, Shafer 481; Cedro, Underwood \& Earle 1451, 1459.

Grisebach's specimen, from western Cuba in 1863, is numbered " $919=3429 . "$ Wright's 3429 in the Gray Herbarium is labeled, "Wet savannas, Candelaria, June 3," and "Savannas near Pinar del Rio, Dec. 11:"

22. ERIOChLOA H. B. K. Nov. Gen. \& Sp. 1:94. pl. 30. 31.1816.

Blades filiform........................................... filifolia.

Blades flat.

Fruit tipped with a slender awn $1 \mathrm{~mm}$. long; blades 7 to $15 \mathrm{~mm}$. wide .......................................... E. punctata.

Fruit merely apiculate; blades 2 to $3 \mathrm{~mm}$. wide.............. E. ramosa.

\section{Eriochloa filifolia sp. nov.}

Plant cespitose; culms numerous, very slender, almost capillary, glabrous, 10 to $20 \mathrm{~cm}$. high, erect or more or less geniculate below; leaves glabrous, blades very narrow, convolute-setaceous, the lower about $10 \mathrm{~cm}$. long, the upper shorter, the uppermost 1 to $2 \mathrm{~cm}$.; spikes mostly 2 , erect, 1 to $2 \mathrm{~cm}$. long, one terminal, the other 5 to $10 \mathrm{~mm}$. below; rachis capillary, minutely pubescent or scabrous, pubescent at base; spikelets 4 to $8,3 \mathrm{~mm}$. long, secund in a single row, the pedicels slender, about $1 \mathrm{~mm}$. long, the cup or joint dark-colored; glume and sterile lemma about 
equal, ovate-acuminate, pilose with appressed hairs, sterile lemma empty; fertile lemma oval, glabrous, $1.5 \mathrm{~mm}$. long, tipped with a slender scabrous awn about 1 $\mathrm{mm}$. long.

Jata Hills near Guanabacoa, Hitchcock, March 15, 1906, no. 559392 in the U. S. National Herbarium (type).

2. Eriochloa punctata (L.) Hamilt. Prod. Fl. Ind. Occ. 5. 1825.

Milium punctatum L. Syst. ed. 10. 2: 872. 1759.

Wright 1542; Yumary Mountains, Rugel 889 in Herb. N. Y. Bot. Gard.

There are two specimens of this species in the Grisebach Herbarium, both irom eastern Cuba, one collected in 1859, marked 1542, the other in 1860 , with the secondary number 95 . In the Gray Herbarium there are also two sheets of the same, one collected near Monte Verde, eastern Cuba, in 1859, "River bank Saltadero, Sept. 11," the other from "Sand bars of the Baracoa near N. Sophie, Sept. 11," 1860-1864.

3. Eriochloa ramosa (Retz.) Kuntze, Rev. Gen. Pl. 2: 775. 1891.

Milium ramosum Retz. Obs. 6: 22. 1791.

Paspalus annulatus Flügge, Mon. Pasp. 133. 1810:

Eriochloa annulata Kunth, Rev. Gram. 1:30. 1829.

Wright 3886. 3850 ( Hb. kretkrb.)

This agrees with Asiatic specimens and may be introduced. It differs from $E$. punctata in the narrower blades and the shorter awn to the fruit.

Allied to these is the Porto Rican Eriochloa subglabra (Nash). (Monachne subglabra Nash, Bull. Torr. Club 30: 374. 1903; Eriochloa punctata subglabra Urban, Symb. Antill. 4: 85. 1903). This species differs from $E$. ramosa in the broader blades and pronouncedly velvety nodes, and in habit; from $E$. punctata in the mucronate, instead of slender-awned, fertile lemma, and from both in having a staminate flower in the axil of the sterile lemma. Urban reduced this to a variety of $E$. punctata without having seen the plant.

23. ISACHNE R. Br. Prod. 196. 1810.

1. Isachne leersioides Griseb. Mem. Amer. Acad. n. ser. 8: 533. 1862.

Wright 755 in National Herbarium (1547 in Sauvalle Herbarium).

Number 755 in the Sauvalle Herbarium is Panicum exiguiflorum. In the Grisebach Herbarium there are two specimens of Isachne leersioides collected by Wright in eastern Cuba-one in 1859, numbered 755, and one in 1860, numbered 102. In the Gray Herbarium there are three specimens bearing the number 755 . One is $P$. exiguiflorum; the other two are Isachne leersioides, both from eastern Cuba-one in $1856-57$, the other from Monte Verde in 1859. Isachne leersioides is listed in Sauvalle's Flora Cubana as no. 1547.

24. SYNTHERISMA Walt. Fl. Car. 76. 1788.

Rachis of racemes wing-angled.

Spikelets 3 to $4 \mathrm{~mm}$. long, more or less villous on nerves; rachis

not pilose........................................... S. sanguinalis.

Spikelets $2 \mathrm{~mm}$. long, glabrous; rachis sparsely long-pilose..... 1. S. digitata.

Rachis of racemes angled but scarcely winged.

Spikelets about $3 \mathrm{~mm}$. long, nearly glabrous................5. S. simpsoni.

Spikelets 1.5 to $2.5 \mathrm{~mm}$. long, usually villous-ciliate.

Racemes usually less than $10 \mathrm{~cm}$. long; spikelets $1.5 \mathrm{~mm}$.

long.......................................... S. filiformis.

Racemes usually more than $10 \mathrm{~cm}$. long; spikelets 2 to 2.5

$\mathrm{mm}$. long. 
Blades much elongated, mostly 30 to $40 \mathrm{~cm}$. long, nearly glabrous; spikelets about $2.5 \mathrm{~mm}$. long........3. S. leucocoma.

Blades shorter, mostly 10 to $20 \mathrm{~cm}$. long, woolly-villous; spikelets about $2 \mathrm{~mm}$. long......................6. S. villosa.

1. Syntherisma digitata (Sw.) Hitchc. Contr. Nat. Herb. 12: 142. 1908.

Milium digitatum Sw. Prod. 24. 1788.

Digitaria setosa Desv.; Hamilt. Prod. F1. Ind. Occ. 6. 1825.

Syntherisma setosa Nash, Bull. Torr. Club 25: 300. 1898.

Wright 764 in part; Herradura, Tracy 9049, Hitchcock in 1906; Isle of Pines, Curtiss in 1904 in Herb. N. Y. Bot. Gard.

In the Grisebach Herbarium are two Wright specimens, no. 177 of 1865, "Bushy savannas, Hanabana, May 29," and no. 764 from eastern Cuba, 1856-57. Wright's 764 from eastern Cuba in 1856-57 in the Gray Herbarium is a mixture of $S$. digitata and $S$. sanguinalis; no. 764 of 1865 is the latter species only.

2. Syntherisma filiformis (L.) Nash, Bull. Torr. Club 22: 420. 1895.

Panicum filiforme L. Sp. Pl. 57. 1753.

Panicum curvinerve Hack. Oesterr. Bot. Zeitschr. 51: 335. 1901.

Wright 1544 in part.

The specimen of Wright's 1544 in the National Herbarium labeled, "Sandy pine woods, Pinar del Rio, Sept.," is partly this and partly S. leucocoma Nash. Hackel $a$ bases his $P$. curvinerve upon this portion of Wright 1544 . The characters which he mentions, such as the smooth glumes with incurving nerves, are found not infrequently among specimens of $S$. filiformis from the northern United States, whence the type was collected by Kalm. In the specimen of 1544 in the National Herbarium (the smaller portion with spikelets only $1.5 \mathrm{~mm}$. long) part of the panicles have nearly glabrous spikelets, and part have long-pubescent spikelets. This differs distinctly from the other part of Wright 1544, which Hackel may have taken for the true $S$. filiformis. The amount of pubescence upon the spikelet is quite variable in this species as in others of this genus. The size of the spikelets, however, is fairly constant. In the Grisebach Herbarium there are two specimens of this from eastern Cuba, one collected in 1859 numbered 1544, the other in 1860 numbered " $107=1544$."

3. Syntherisma leucocoma Nash, Bull. Torr. Club 25: 295. 1898.

Sandy pine woods in large tufts, Pinar del Rio, September, Wright 1544, in part; Herradura, Hitchcock in 1906.

Spikelets $2.5 \mathrm{~mm}$. long; plants mostly glabrous or nearly so, tall, with elongated narrow blades and slender erect racemes as much as $25 \mathrm{~cm}$. long.

4. Syntherisma sanguinalis (L.) Dulac, Fl. Haut. Pyr. 77. 1867.

Panicum sanguinale L. Sp. P1. 57. 1753.

Asperella digitaria Lam. Tabl. Encycl. 1: 167. 1791.

La Fermina, June 17, Wright 3883; Wright 764 in part; Habana, Curtiss 655, Hitchcock in 1906, Leon 301, 304; Santiago de las Vegas, Hitchcock in 1906, Baker HC 501; Puentes Grandes, Leon 279; Guanabacoa, Hitchcock in 1906; Batabano, Hitchcock in 1906; Cienfuegos, Pringle 46 in the Gray Herbarium; Guines, Leon 304 . The following are in the herbarium of the New York Botanical Garden: Santiago de Cuba, Taylor 50; Isle of Pines, Curtiss in 1904; Rincon, Britton \& Wilson 485; Matanzas, Britton \& Shafer 333; Bayamese, Eggers 4690.

The sheet of 764 in the National Herbarium, like that in the Sauvalle Herbarium, consists of a mixture of this species and $S$. digitata. In the latter herbarium this number has two labels, one "Savannas, S. Cristobal, Aug.," the other "Sandy pine woods, Pinar del Rio, Sept." No. 764 in the National Herbarium has the label, 
"Savannas, Retiro, July." In the Grisebach Herbarium there are two specimens from Wright. One collected in 1865 and numbered 178, and 294 ("var. eriogona"); the other without number, labeled "Roads and fields, common, Hanabana, May 21."

Lamarck's type, labeled "Asperella digitaria lam. ill. ex. D. Richard," is in the Lamarck Herbarium in the Museum at Paris.

5. Syntherisma simpsoni (Vasey) Nash, Bull. Torr. Club 25: 297. 1898.

Panicum sanguinale simpsoni Vasey, Contr. Nat. Herb. 3: 25. 1892.

Isle of Pines, Curtiss 521.

Spikelets glabrous, $2.5 \mathrm{~mm}$. long, the glume and sterile lemma equal and slightly exceeding the fruit. Syntherisma aequiglumis (Hack. \& Arech.) (Panicum aequiglume Hack. \& Arech. in Arech. Gram. Urug. 93. 1894) differs in having larger spikelets, $3.5 \mathrm{~mm}$. long, the acuminate sparsely pubescent glume and sterile lemma exceed-ing the fruit by $0.5 \mathrm{~mm}$.

6. Syntherisma villosa Walt. Fl. Car. 77. 1788.

Sandy pinales, La Grifa la Catolina, Pinar del Rio, January, Wright 3884; Herradura, Tracy 9077, 9104.

There are two specimens in the Grisebach Herbarium, one marked "Edge of woods, bushy savannas, Hanabana, May 30 ," 1865, numbered 173, the other, "Bushy savannas, Hanabana, May 27," 1865 . Spikelets about $2 \mathrm{~mm}$. long; plant pubescent or nearly glabrous.

25. VALOTA Adans. Fam. P1. 2: 495. 1763.

1. Valota insularis (L.) Chase, Proc Biol. Soc. Wash. 19: 188. 1906.

Andropogon insulare L. Syst. Nat. ed. 10. 2: 1304. 1759.

Panicum leucophaeum H. B. K. Nov. Gen. \& Sp. 1: 87. 1816.

Panicum duchaissingii Steud. Syn. P1. Glum. 1: 93. 1854.

Sảntiago de las Vegas, Baker HC 602, 1473, Hitchcock in 1906; Vento, Schafer in 1903; Triscornia,. Tracy. 9083; Herradura, Tracy 9050; San Luis, Pollard \& Palmer 350; Matanzas, Rugel 191 in Gray Herbarium; Cienfuegos, Pringle 44 and Combs 255 in Gray Herbarium; Marianao, Leon 306. The following are in the herbarium of the New York Botanical Garden: Santiago de Cuba, Hamilton 216, 217, Underwood \& Earle 165; Matanzas, Britton \& Shafer 165, Britton \& Wilson 101; Cedro, Underwood \& Earle 1536.

In the Grisebach Herbarium is a Wright specimen from eastern Cuba, 1859, numbered 1541 .

Steudel's type from "Ins. Guadaloupe Duchaissing" is in the Museum at Paris.

26. ALLOTEROPSIS Presl, Rel. Haenk. 343. pl. 47. 1830. $a$

Blades elongated, 30 to $40 \mathrm{~cm}$. long; racemes several in a cluster . 2. A. dura. Blades mostly radical, 10 to $15 \mathrm{~cm}$. long; racemes 1 or $2 \ldots . . .1$. A. amphistemon.

a The type species is $A$. distachya Presl (op. cit. 344), which is published as coming from Monterey, California, but the type in the National Museum at Prague has two labels, "Peruana montana," and "Regio montana Luzon?" The plant is Alloteropsis semialata (R. Br.); Panicum semialatum R. Br. Prod. 192. 1810, the type of which is from New Holland. This is not an American species and Presl's type must have come from the Philippines, as indicated by Scribner (Rep. Mo. Bot. Gard. 10: 37. 1899). Presl's plate and description are incorrect in that the artist incorporated in the drawing of the spikelet of Alloteropsis a spikelet of an Andropogon which had become wedged between the glumes and this is described as a second pair of spikelets. Although Presl's genus is founded upon a misconception there is no doulbt as to the identity of the type species. Hence Alloteropsis, the oldest name for this group as segregated from Panicum, is accepted for the genus. 


\section{Alloteropsis amphistemon (Wright).}

Panicum amphistemon Wright, Anal. Acad. Cienc. Habana 8: 207. 1871;-Sauv. Fl. "Cub, 198.

Wright 3464.

The type of Panicum amphistemon Wright is in the Gray Herbarium, Wright 3164, labeled "Mayarí-abajo, Aug. 2, in small dense tufts."

\section{Alloteropsis dura (Griseb.).}

Panicum durum Griseb. Mem. Amer. Acad. n. ser. 8: 533. 1862.

Rocky hills, procumbent in loose tufts, Valestina, September 25, Wright 3868; in small tufts on steep hills at the Farallones, N. Sophie, September 29 , Wright 1539 in the Gray Herbarium.

In the Grisebach Herbarium is the type of $P$. durum, Wright $15 \overrightarrow{0} 9$ from eastern Cuba in 1859.

\section{MESOSETUM Steud. Syn. P1. Glum. 1: 118. 1854.a.}

Spikelets copiously villous-ciliate ........................ M. rottboellioides. Spikelets glabrous or somewhat hispid .................... Mrightii.

1. Mesosetum rottboelliodes (H. B. K.).

Panicum rottboellioides H. B. K. Nov. Gen. \& Sp. 1:96. 1816.

Mesosetum cayennense Steud. Syn. Pl. Glum. 1: 118. 1854.

Culms scattered, single or few, savannas, Matatoso, August, Wright 3449; Herradura, Baker HC 2935, Tracy 9058, Hitchcock in 1.106; Isle of Pines, Curtiss 396, Palmer \& Riley 889, 896, Taylor 31; Cienfuegos, Combs 401 in Gray Herbarium; Sagua, Britton \& Wilson 336 in Herb. N. Y. Bot. Gard.

The Sauvalle specimen has a second label which reads, "In small tufts, Pinales, Daganiguas, Almacigos Consolacion, Sept." The Grisebach specimen from western Cuba, 1863, is numbered " $894=3449 . "$ Wright 3449 in the Gray Herbarium is from "Savannas, Vueltabajo, July 24."

\section{Mesosetum wrightii sp. nov.}

Culms ascending from a geniculate, rooting or creeping base, slender, glabrous, 20 to $40 \mathrm{~cm}$. long; nodes appressed-hispid; sheaths glabrous below, hispid toward the summit, or the lower hispid throughout, ciliate on the margin; ligule of short bristles; blades flat or somewhat involute on the margins, stiff and thick, yellowgreen, hispid below and sparsely so above, remotely papillose-ciliate on the cartilaginous margins, 3 to $6 \mathrm{~cm}$. long, 2 to $3 \mathrm{~mm}$. wide, the uppermost much reduced; spike single, terminating the culm, mostly long-exserted, 2 to $3 \mathrm{~cm}$. long; spikelets subsessile, appressed to the rachis, alternate, 3 to $4 \mathrm{~mm}$. long, the apex of one about reaching the base of the one above on the same side; first glume glabrous, 3-nerved, narrow, acuminate to a blunt point, a little shorter than the second, placed next to the rachis; second glume hispid at the base with a tuft of hairs, sparsely or copiously hispid above, strongly 5-nerved and with some additional striæ, narrowed to a blunt apex; sterile lemma similar, somewhat gibbous below, 7-nerved, its palea obsolete; fertile lemma chartaceous, smooth, and shining, rounded on the back so as to be as thick as wide, about $2 \mathrm{~mm}$. long, extended into a short point, the margins flat, not inrolled; palea similar and included in the margins of the lemma.

Type specimen from Cuba, Wright 3859 no. 559961 in the U. S. National Herbarium. The fragmentary specimen in the Sauvalle Herbarium bears the label

$a$ Mesosetum Steud. Flora 33: 228. 1850, nomen nudum. The type species of Mesosetum is M. cayennense Steud., "Leprieur legit. in Cayenne," the type specimen of which, in the herbarium of the Museum at Paris, belongs to the same species as that of Panicum rottboellioides H. B. K. in the same herbarium. 
"Pinales, Daganiguas, Almicigos, Sept." Panicum sclerochloa Trin.a (Mesosetum sclerochloa (Trin.)) of Brazil, the type of which is in the Trinius Herbarium, differs in having glabrous blades, spikelets $5 \mathrm{~mm}$. long, somewhat scabrous but not hispid, and glumes and lemmas all notched near the apex, hence somewhat 3-lobed. In Sauvalle's Flora Cubana Wright 3859 is doubtfully referred to Panicum sclerochloa Trin.

28. BRACHIARIA Griseb. in Ledeb. Fl. Ross. 4: 469. 1853.

1. Brachiaria plantaginea (Link).

Panicum plantagineum Link, Hort. Berol. 1: 206. 1827.

Panicum leandri Trin. Icon. 335. 1836.

Paspalum platyphyllum Griseb. Cat. Pl. Cub. 230. 1866.

Panicum platyphyllum Munro; Vasey, U. S. Dept. Agr. Div. Bot. Bull. 8: 25. 1889.

Brachiaria platyphylla Nash in Small, Fl. Southeast. U. S. 81. 1903.

Wright 3853, 3441; in dense patches in pasture, Sabinilla, June, Wright 3867.

The type of Link's species is in the Berlin Herbarium. Wright's 3853 in the Sauvalle Herbarium bears the secondary number 174 . In the Grisebach Herbarium are two specimens, the type of Paspalum platyphyllum from western Cuba, 1863, numbered " $892=3441$ " and no. 174 labeled, "Damp places in roads and elsewhere, Zarabanda, May 4." This species is placed in the genus Brachiaria because the spikelets are placed with the first glume toward the rachis.

29. HYMENACHNE Beauv. Agrost. 48, pl. 10.f. 8. 1812.

Inflorescence spike-like; spikelets $4 \mathrm{~mm}$. long................. 1. H. amplexicautis. Inflorescence of numerous spikes, 1 to $3 \mathrm{~cm}$. long; spikelets 2 to

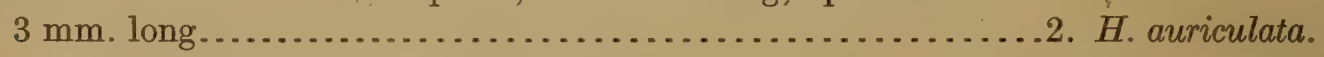

1. Hymenachne amplexicaulis (Rudge) Nees, Agrost. Bras. 276. 1829.

Panicum amplexicaule Rudge, Pl. Guian. 1: 21. 1805.

Panicum hymenachne Desv. Opusc. 82. 1831.

Panicum myuros of authors, not Lam. $b$

Wright 3469; Santiago de las Vegas, Hitchcock in 1906; Habana, Leon 559; Guines, Leon 577.

The specimen in the Grisebach Herbarium is from eastern Cuba, 1860, and is num.bered " $108=3469$." No.3469 in the Gray Herbarium is from "Margin of Rio Bayamo, Oct.14."

2. Hymenachne auriculata (Willd.) Chase, Proc. Biol. Soc. Wash. 21: 5. 1908.

Panicum auriculatum Willd.; Spreng. Syst. 1: 322.1825.

Wriaht 3863 in part.

Theı are three labels with this specimen in the Sauvalle Herbarium, "In ponds, Daganiguas, Sept.," "Wet margin of lagunas, Sta. Cruz de los Piños, Nov. 10," "Low marshy lands, Guanimar, Nov." On the same sheet is a specimen of Panicum condensum Nash, and one of $P$. laxum Sw.

The specimen of Hymenachne is fragmentary, but appears to belong to this species. Wright's 3863 in the National Herbarium is mixed with Panicum laxum Sw. Wright's 3863 in the Gray Herbarium is mixed with $P$. condensum.

30. SACCIOLEPIS Nash in Britton, Man. 89. 1901.

Spikelets $4 \mathrm{~mm}$. long, on slender pedicels........................ . S. striata. Spikelets 2 to $3 \mathrm{~mm}$. long, subsessile. 
Spikelets $2 \mathrm{~mm}$. long, panicle dense......................... 1. S. myuros.

Spikelets $3 \mathrm{~mm}$. long, pạnicle often interrupted............... 3. S. vilvoides.

1. Sacciolepis myuros (Lam.) Chase, Proc. Biol. Soc. Wash. 21: 7. 1908.

Panicum myuros Lam. Tabl. Encycl. 1: 172. 1791.

Isle of Pines, Curtiss 428.

2. Sacciolepis striata (L.) Nash, Bull. Torr. Club 30: 383. 1903.

Holcus striatus L. Sp. Pl. 1048. 1753.

Panicum gibbum Ell. Bot. S. C. \& Ga. 1: 116. 1816

On tembladeros $a$ in lagunas, Pinar del Rio, December, Wright 3885.

The Grisebach specimen is from Hanabana, May 25, 1865, numbered 198. A specimen in the Gray Herbarium is numbered " $302=3885$."

3. Sacciolepis vilvoides (Trin.) Chase, Proc. Biol. Soc. Wash. 21: 7. 1908.

Panicum vilvoides Trin. Gram. Pan. 171. 1826.

Hymenachne fluviatilis Nees, Agrost. Bras. 273. 1829.

In rivulets, Pinar del Rio, October, Wright 3470; Isle of Pines, Curtiss 304.

This species is represented in the Grisebach Herbarium by a Wright specimen from western Cuba, 1863, numbered " $944=3470$." Wright's 3470 in the Gray Herbarium is labeled, "In lagunas, Los Almacigos, Nov. 23," and "On tembladeros $a$ in lagunas, Asiento viejo de San Julian, Nov. 30."

31. ECHINOCHLOA Beauv. Agrost. 53. pl. 11.f. 2. 1812.

Sheaths hirsute..................................... walteri.

Sheaths glabrous.

Spikelets pointed but not awned............................ E. colona.

Spikelets awned....................................... E. crusgalli.

1. Echinochloa colona (L.) Link, Hort. Berol. 2: 209. 1833.

Panicum colonum L. Syst. Nat. ed. 10. 2: 870. 1759.

Wright 752; Habana, Baker HC 1796, Leon 303, Palmer \& Riley 1137; Santiago de las Vegas, Baker HC 502, 4765, Hitchcock in 1906; Buena Vista, Shafer in 1903; Cerro, Shafer 180; Guanabacoa, Leon 117 in part; Cabañas, Palmer \& Riley 756; Cienfuegos, Pringle 45; Combs 254 in Gray Herbarium; Guines, Leon 425. The following are in the herbarium of the New York Botanical Garden: Isle of Pines, Curtiss 427; Matanzas, Britton \& Shafer 509; Cedro, Underwood \& Earle 1620.

In the Grisebach Herbarium there are two specimens, one from western Cuba, 1863 , "946=752," the other numbered 27, collected in 1865 .

A specimen in the herbarium of the New York Botanical Garden from Matanzas, Rugel 884, is doubtfully referred to $E$. colona. The spikelets have awns 2 to $3 \mathrm{~mm}$. long.

2. Echinochloa crusgalli (L.) Beauv. Agrost. 53. 1812.

Panicum crusgalli L. Sp. Pl. 56. 1753.

Santiago, Linden 1814 in Leipzig Herbarium; Rugel 889 in Grisebach Herbarium;

Wright in 1865 in Grisebach Herbarium; Wright 53 of 1865 in Kew Herbarium; Isle of Pines, Curtiss in 1904 in Herb. N. Y. Bot. Gard.; Matanzas, Britton \& Witson 175 in Herb. N. Y. Bot. Gard. Wr.38>९ p.p. L-Nat. Hl.

3. Echinochloa walteri (Pursh).Nash in Britton, Man. 78. 1901.

Panicum walteri Pursh, Fl. Sept. Amer. 1: 66. 1814.

Low wooded swamps, Hanabana, May 27, Wright 3879; Wright 160 in Kew Herbarium. $\gamma$

a Quaking bogs.

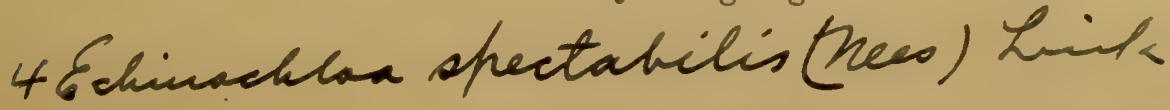


There are two additional labels with Wright 3879 in the Sauvalle Herbarium, "Low marshy savannas, Guanimas, Nov.," and "Margin of mangrove swamp, Trinidad, Mar. 13.".

32. PANICUM L. Sp. P1. 55. 1753 .

Axis of the panicle branches extending beyond base of uppermost

spikelet as a short point or bristle....................11. P. distantiflorum.

Axis of panicle branches not extended into a bristle.

Inflorescence consisting of several spike-like, more or less secund racemes.

Fruit smooth and shining; spikelets not over $1.5 \mathrm{~mm}$.

long. (LAXUM GROUP.)

Rachis pilose; pedicel short, subequal............32. P. pilosum.

Rachis not pilose; pedicels unequal, panicle less regular...............................23. P. laxum.

Fruit transversely wrinkled; spikelets turgid. (REPTANS GROUP.)

Nodes bearded. 29. P. numidianum.

Nodes sometimes pubescent, but not bearded.

Glumes and sterile lemma prominently transversely reticulate-veined.

15. P. fasciculatum.

Glumes and sterile lemma not cross-veined.

Spikelets hispidulous, pointed, first glume acute.

Spikelets glabrous, first glume truncate.

Blades ovate-lanceolate, 5 to $10 \mathrm{~mm}$. wide, 2 to $7 \mathrm{~cm}$. long; prostratespreading.

..35. P. reptans.

Blades elongated, 10 to $20 \mathrm{~cm}$. long, narrow; flowering culms erect or ascending; inflorescence of numerous erect-appressed racemes on an elongated axis; spikelets in 2 distinct rows........................ 17. P.geminatum.

Inflorescence a more or less diffuse panicle, sometimes narrow and rather compact, but not consisting of spikelike racemes.

Stems woody, rêsembling bamboos. (Divaricatum GROUP.)

Sheaths villous.

Stems tall, blades 1 to $2 \mathrm{~cm}$. wide, not distichous.............................. 42. P. swartzianum.

Stems creeping, blades distichous, 2 to $3 \mathrm{~cm}$. long, about $5 \mathrm{~mm}$. wide, velvety...........36. P. rugelii.

Sheaths smooth or pubescent only.

Panicle compact; blades ovate-lanceolate, 1.5 to $4 \mathrm{~cm}$. wide, velvety-puberulent beneath; spikelets globular 2. P. adspersum. Panicle open, blades lanceolate.

Stem creeping, sending up erect flowering culms 19. P. grisebachii.

Stem climbing or trailing.

Panicle large and spreading, 10 to 20 $\mathrm{cm}$. long; blades 1.5 to $2.5 \mathrm{~cm}$. wide. 39. P. sloanei. 
Panicle small and few-flowered, usually about $5 \mathrm{~cm}$. long; blades usually 5 to $8 \mathrm{~mm}$. wide................... 12. P. divaricatum.

Stems herbaceous.

Fruit transversely rugose. 25. P. maximum. (Continuation 1.)

Fruit smooth. (See continuation 1.)

Plants forming a rosette of basal leaves in autumn; early culms -simple, with terminal, exserted, many-flowered, spreading panicles; freely branching after maturity of primary panicle, and bearing numerous reduced panicles more or less included in the sheaths. (DichotomuM GROUP.)

Ligule a ring of hairs, $1 \mathrm{~mm}$. or more long; spikelets pubescent, 1 to $1.5 \mathrm{~mm}$. long.

Spikelets hardly $1 \mathrm{~mm}$. long; foliage minutely pubes-

cent, not velvety........................ 48. P. wrightianum.

Spikelets $1.5 \mathrm{~mm}$. long.

Foliage smooth or minutely puberulent.........24. P. leucothrix.

Foliage velvety .......................... 1. P. acuminatum.

Ligule inconspicuous.

Autumnal state a flat mat or rosette of soft leaves;

blades ciliate; spikelets 1.5 to $2 \mathrm{~mm}$. long, glabrous.

Blades pilose on the surface................... .41. P. strigosum.

Blades glabrous on the surface.................33. P. polycaulon.

Autumnal state erect or spreading.

Sheaths velvety or pilose.

Vernal culms 1 meter or more tall, a viscid ring below each node; primary panicles 10 to $20 \mathrm{~cm}$. long; autumnal blades, $5 \mathrm{~mm}$. or more wide..................... 37. P. scoparium.

Vernal culms 20 to $40 \mathrm{~cm}$. tall; primary panicles 2 to $6 \mathrm{~cm}$. long; autumnal blades 1 to $2 \mathrm{~mm}$. wide. 6. P.chrysopsidifolium.

Sheaths not velvety nor pilose.

Culms wiry, minutely crisp-puberulent; spikelets pyriform-turgid.

Spikelets $1.5 \mathrm{~mm}$. long ............... 31. P. pauciciliatum.

Spikelets $2 \mathrm{~mm}$. long............... 22. P. lancearium.

Culms glabrous, or only lowermost internodes pubescent.

Spikelets glabrous, $1.6 \mathrm{~mm}$. long...... 7. P. caerulescens.

Spikelets pubescent.

Nodes bearded; spikelets $2 \mathrm{~mm}$. long 28. P. nitidum.

Nodes glabrous or pubescent, not bearded.

Blades long and narrow, autumnalbladesinvolute; spikelets papillose.

Spikelets $2 \mathrm{~mm}$. long, blunt.27. P. neuranthum. Spikelets about $3.5 \mathrm{~mm}$.

long, pointed..........16. P. fusiforme.

Bladesnot elongated, autumnal blades flat; spikelets not papillose. 
Plants not forming winter rosettes.
Blades with a white-carti- laginous margin, not cili- ate; spikelets $1.5 \mathrm{~mm}$. long .................44. P. tenue.
Blades without white mar- gin, ciliate toward the cordate base; spikelets scarcely over $1 \mathrm{~mm}$. long, suborbicular.......... 13. P:erectifolium.

Panicles narrow and compact with appressed branches; spikelets glabrous, 1 to $2.5 \mathrm{~mm}$. long.

Culms 1 meter or more tall, compressed at base; panicle 10 to $20 \mathrm{~cm}$. long; spikelets $2.5 \mathrm{~mm}$. long.... . Culms $60 \mathrm{~cm}$. or less tall, stiff and wiry, base not compressed; panicle less than $5 \mathrm{~cm}$. long; spikelets 1 to $2 \mathrm{~mm}$. long.

Spikelets scarcely more than $1 \mathrm{~mm}$. long........ 40. P. stenodes.

Spikelets $2 \mathrm{~mm}$. long ...................... 43. P. tenerum.

Panicles open, usually diffusely spreading.

Panicle branches in several distinct distant whorls; spikelets short-pediceled, remote along the branches...............................26. P. megiston.

Panicle branches not in distinct whorls.

Spikelets 5 to $6 \mathrm{~mm}$. long, pedicels short and stout; panicle branches few, ascending.......49. P. zizanioides.

Spikelets less than $5 \mathrm{~mm}$. long, pedicels slender, often capillary.

Plants producing scaly rootstocks.

Blades 5 to $15 \mathrm{~cm}$. long; culms less than $50 \mathrm{~cm}$. tall; a sea-shore grass .....34. P. repens.

Blades elongated, 20 to $40 \mathrm{~cm}$. long; culms 1 meter or more tall. . . . . . . . 47. P. virgatum cubense.

Plants not producing rootstocks, but culms sometimes decumbent and rooting at base.

Spikelets glutinous, $3 \mathrm{~mm}$. long .........18. P.glutinosum.

Spikelets not glutinous. (See continuation 2.)

\section{(Continuation 2.)}

Spikelets warty-rugose, about $2 \mathrm{~mm}$. long; blades ovatelanceolate. 38. P. sellovii.

Spikelets not rugose.

Spikelets pubescent, minute (1 mm. long); blades ovate-

lanceolate. 46. P. trichoides.

Spikelets glabrous.

Spikelets $1.5 \mathrm{~mm}$. long, short-pediceled on the spreading branches of a panicle 2 to $5 \mathrm{~cm}$. long; culms slender, 30 to $50 \mathrm{~cm}$. high, blades 1 to $2 \mathrm{~mm}$. wide.14. P. exiguiflorum.

Spikelets on more or less elongated pedicels.

Culms slender, widely decumbent-spreading; blades elliptic-lanceolate, 1 to $3 \mathrm{~cm}$. long, glaucous. 30. P. parvifolium. 
Culms not slender nor decumbent-spreading.

First glume obtuse or truncate, one-fourth

the length of the acuminate spikelet...... 5. P. chloroticum.

First glume acute to acuminate, more than one-third the length of the spikelet.

Sheaths glabrous.

Panicle very diffuse, the branches capillary; spikelets less than $\mathbf{1 . 5}$ mm. long.................... 45. P. tricanthum.

Paniclescarcely diffuse, the branches not capillary; spikelets $2 \mathrm{~mm}$. or more long.

Culms slender; spikelets $2 \mathrm{~mm}$. long ..................... P. diffusum.

Culms tall and stout, 5 to $10 \mathrm{~mm}$. in diameter; spikelets acuminate, about $5 \mathrm{~mm}$. long ....... 3. P. aquaticum. Sheaths hispid.

Annual; panicle branches divaricate ..................... 4. P. cayennense.

Perennial; panicle branches ascending.

Spikelets $2 \mathrm{~mm}$. long, panicle compact ................20. P. hirsutum.

Spikelets $3 \mathrm{~mm}$. long, panicle loose ...................21. P. hirtivaginum.

1. Panicum acuminatum Sw. Prod. 23. 1788.

Panicum comophyllum Nash, Bull. Torr. Club 30: 380. 1903.

Dry savannas, San Cristobal, August, Wright 3874; Herradura, Baker \& Dimmock HC 4871, Tracy 9078, Hitchcock in 1906; Pinar del Rio, Shafer 320 in part, Pulmer \& Riley 447; Isle of Pines, Curtiss 328, 307, Taylor in 1901, Palmer \& Riley 989, 1065, 1083, Taylor 33 in Herb. N. Y. Bot. Gard.

The type of $P$. acuminatum at Stockholm is a specimen in the autumnal state. Wright's 3874 in the Gray Herbarium is labeled "Low savannas, Chirigote, Nov. 2." Another specimen in the Gray Herbarium, without number, is from "Savannas, Pueblo Nuevo, San Cristobal, May 16."

2. Panicum adspersum Trin. Gram. Pan. 146. 1826.

Wright 3869; Santiago de las Vegas, Baker HC 387, 512, 1050, 1825, 2057, Hitchcock in 1906, Tracy 9109; Triscornia, Hitchcock in 1906; Habana, Curtiss 748, Leon 291, 570; Herradura, Tracy 9102; Cabañas, Palmer \& Riley 746, 771; Matanzas, Britton, Britton \& Shafer 596. In the Herbarium of the New York Botanical Garden are the following: Isle of Pines, Curtiss in 1904; Pinar del Rio, Shafer 504.

Wright's specimen in the Sauvalle Herbarium bears the secondary number 304 in addition to the distribution number. Grisebach's specimen bears the secondary number 304 (1865). The specimen in the Gray Herbarium bears the secondary number 269. Trinius's type is from Santo Domingo, sent by Sprengel, and is the plant from which the plate is drawn. ${ }^{a}$ The spikelets are about $3 \mathrm{~mm}$. long and sparsely hispidulous. The culms are'geniculate and rooting below; the blades spreading and 4 to $8 \mathrm{~cm}$. long. A larger form occurs in Florida, with culms as much as 1 meter high, and blades $15 \mathrm{~cm}$. long and $1.5 \mathrm{~cm}$. wide, the spikelets larger, as much as $4 \mathrm{~mm}$. long. This is represented in Cuba by Curtiss 748 and Palmer \& Riley 771. An examination of considerable material from the West Indies and Flor- 
ida shows that there are all gradations between these extremes, and there appears to be no constant character by which to separate the larger form as a species or even as a well-marked variety.

3. Panicum aquaticum Poir. Encycl. Suppl. 4 : 281. 1816.

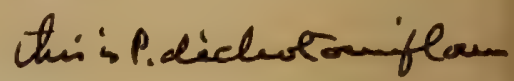

Panicum elephantipes Nees, Agrost. Bras. 165. 1829.

San Antonio, Hitchcock in 1906, Habana, Leon 335.

Poiret's type labeled "Panicum aquaticum enc. suppl. * * * Porto Ricco. h. Poiret" is in the herbarium of Cosson in Paris. Nees's type at Munich agrees with this.

4. Panicum cayennense Lam. Tabl. Encycl. 1: 173. 1791.

Among other tall grasses in low grounds, pinales, Pinar del Rio, September, Wright 3865; Herradura, Tracy 9073; Isle of Pines, Curtiss 267, Palmer \& Riley 1086, Taylor 34 .

The Grisebach specimen is from western Cuba, 1863, no. 891. A specimen of this species in the Gray Herbarium, without number, is from "Savannas, Vueltabajo, July 28."

5. Panicum chloroticum Nees; Agrost. Bras: 164. 1829. Trim Ream.Pan.2 36.1826

Punta Brava, Baker HC 4054; Santiago de las Vegas, Hitchcock in 1906; Batabano, Hitchcock in 1906; Herradura, Hitchcock in 1906, Tracy 9055; Wright 3456 and 3860 in National Herbarium in part; Wright 3860 in Sauvalle Herbarium; Wright 181, 189 in the Grisebach Herbarium; Wright 3456 in Sauvalle Herbarium; edge of Lagunas, Pinar del Rio, September, Wright 3861.

The first two specimens cited above are like the type at Munich; the others are more or less pubescent, but appear to be otherwise the same. The type of Panicum proliferum pilosum Griseb. in the Grisebach Herbarium is labeled "Around lagunas in wet or damp ground, Hanabana, May 16," no. 186. This is the same as Wright 3860 in the Sauvalle Herbarium. Probably P. bartowense Scribn. \& Merr. ${ }^{a}$ is a form of $P$. chloroticum. It differs from the Brazilian specimen only in its hispid sheaths and from some of the hispid Cuban specimenspnly in its larger size. Nash's 567 from Eustis, Florida, is a low spreading form, with culm about $30 \mathrm{~cm}$. long, but the blades and sheaths pubescent like $P$. bartowense. $P$. dichotomiflorum Michx. $b$ (P. proliferum of American authors, not Lam.), common throughout the eastern United States, is smooth throughout, and is usually more or less geniculate-spreading at base, and the blades are usually long and gradually acuminate. In Florida this shows a tendency to become pubescent. Combs \& Rolfs 94 from Lake City, Florida, has the habit of $P$. dichotomiflorum, but the blades are pubescent on the upper surface. The spikelets of $P$. dichotomiflorum vary in length from 2 to $3 \mathrm{~mm}$. It would appear that there is one variable species, including $P$. dichotomiflorum Michx., $P$. chloroticum Nees, and P. bartowense Scribn. \& Merr. The West Indian specimens resemble more closely $P$. chloroticum in habit, and for the present they are referred to this species. Other specimens of the same in the National Herbarium are: Bahamas, Nassau, Curtiss 177; Cat Cay, Brace 3742. Bermuda: Hamilton, Millspaugh 126. Porto Rico: Unado, Britton \& Cowell 432. South America: Brazil, Riedel 959, Salzmann (P. hygrophilum Salzm.); Paraguay, Morong 1002; Uruguay, Arechavaleta.

Wright's 3456 and 3861 cited above have larger spikelets than the other Cuban specimens (3 mm. long), but this appears to be a variable character. Wright 3456 is the type of $P$. proliferum strictum Griseb.c Wright 3456 in the Gray Herbarium is from "Lagunas, Almacigos, Nov. 23."

6. Panicum chrysopsidifolium Nash in Small, Fl. Southeast. U. S. 100. 1903.

Wright 3453 in part; Wright 3454 in part; Wright 3461 in part; Herradura, Hitchcock in 1906; Consolacion del Sur, Palmer \& Riley 481; Isle of Pines, Palmer \& Riley 982.

$a$ U. S. Dept. Agr. Div. Agrost. Circ. 35 : 3. 1901.

$c$ Cat. Pl. Cub. 232. 1866.

$b$ Fl. Bor. Amer. 1 : 48. 1803. 
The Grisebach specimen of Wright 3461 also belongs to this species, though it is listed by him under $P$. dichotomum variety nodiflorum. Another specimen of this was included by Grisebach under $P$. neuranthum; it is labeled " $x$ forma ascendens ramosa." Wright's 3461 in the Gray Herbarium is part $P$. chrysopsidifolium and part $P$. lancearium. The two labels are, "Sandy pinales, Asiento Viejo de San Julian, Dec. 1," and "Pinal. Mayarí, July 24."

This species is distinguished from $P$. neuranthum by the pubescent culms, bearded nodes, spreading vernal panicles, and short, flat autumnal blades on zigzag stems. The spikelets are $2 \mathrm{~mm}$. long. It occurs in Florida and in Porto Rico (Heller 982).

7. Panicum caerulescens Hack. in herb.

Vernal form cespitose, of a somewhat glaucous bluish green color; culms erect or ascending, 40 to $75 \mathrm{~cm}$. high, glabrous; sheaths usually less than half as long as the internodes, glabrous or the basal ones sparingly pubescent; blades ascending or spreading, commonly purplish beneath, glabrous or rarely a few hairs around the base, 5 to $8 \mathrm{~cm}$. long, 4 to $7 \mathrm{~mm}$. wide, the margins nearly parallel for two-thirds their length; panicles usually short-exserted, 3 to $7 \mathrm{~mm}$. long, one-half as wide or less, the branches narrowly ascending; spikelets 1.5 to $1.6 \mathrm{~mm}$. long, $0.9 \mathrm{~mm}$. wide, obovoid, blunt, very turgid, glabrous, first glume about one-third the length of the spikelet; second glume and sterile lemma subequal, the glume scarcely as long as the fruit at maturity; fruit $1.4 \mathrm{~mm}$. long, $0.8 \mathrm{~mm}$. wide, ellipsoid.

Autumnal form erect or leaning, sometimes decumbent at base, producing short, densely fascicled branches at the middle and upper nodes, these tufts scarcely as long as the primary internodes, the reduced blades ascending, more or less involute; the reduced panicles with only a lew long-pediceled spikelets.

Closely related to $P$. roanokense, a species of the southern Atlantic coastal plain of the United States, from which it is distinguished by the narrow panicles and smaller spikelets and by the tufted branches of the autumnal form.

The type is Hitchcock 706, "In glade among Spartina, etc., stretching up through the tall grass, Miami, Florida, April 3, 1906;" U. S. National Herbarium no. 558380. The name refers to the glaucous blue color.

In marshes and swampy woods, southern Alabama and Florida, Cuba, and the Bahamas.

Wright 3463 in part; Santa Clara, Britton \& Wilson 316 in Herb. N. Y. Bot. Gard.

Wright's 3463 in the National Herbarium and in the Krug and Urban Herbarium is this species. For other species distributed as 3463 , see $P$. leucothrix, $P$. wrightianum, and $P$. tenue.

Bahamas, New Providence, "in fruticetis procumbens," Eggers 4305.

8. Panicum compactum Sw. Adnot. Bot. 14. 1829.

Eastern Cuba, 1856-57, Wright 749; Isle of Pines, Curtiss 291, 520, Palmer \& Riley 904.

This species is distinguished by its broad, usually puberulent blades and compact panicle.

9. Panicum condensum Nash in Small, Fl. Southeast. U. S. 93. 1903.

Low savannas, Hanabana, May 19, Wright 3862 in part.

In the Grisebach Herbarium there are two specimens of this species. One of them has two labels, "Low wet woods, Hanabana, May 27," no. 184 of 1865, and "Netamong tall Cyperaceae, in small bunches, Hanabana, May 25." The plant is 3 feet tall, stout, with a compressed base, and narrow compact panicle. The other specimen, which is similar, is labeled, "Palm savannas, Hanabana, May 18," 1865, no. 197. This number of Wright's in the Sauvalle Herbarium and in the National Herbarium is mixed with $P$. laxum. There is a fragment of what appears to be the same, on the sheet of 3863 in the Sauvalle Herbarium. P. condensum is common in the southern United States and is found also in the Bahamas (Curtiss 174). Wright's 3862 in the 
Gray Herbarium consists of $P$. condensum and $P$. laxum. Wright's 3863 in the Gray Herbarium consists of $P$. condensum and Hymenachne auriculata.

10. Panicum diffusum Sw. Prod. 23. 1788.

Wright 1540; in pastures, Retiro, July, Wright 3852; damp savannas, Retiro, October 11, Wright 3877; Santiago de las Vegas, Baker HC 350, 511, 2052, 2054, Tracy 9111, Wilson 1405; Habana, Leon 190, 305, Baker, Tracy \& Hasselbring HC 3095; Triscornia, Tracy 9082; Guanajay, Palmer \& Riley 802; Isle of Pines, Curtiss 384, 494. The following are in the Herbarium of the New York Botanical Garden: Santiago de las Vegas, Van Hermann 2444; Sagua, Britton \& Wilson 314; Madruga, Britton \& Shafer 649; Matanzas, Rugel 907.

A sheet in the National Herbarium of Wright 3860 and another marked "Cuba 3860 ," which appears to be a Wright plant although there is no Wright label, are in part $P$. diffusum. In the Grisebach Herbarium are three specimens marked, respectively, "In the edge of woods and margin of savannas, Hanabana, May 29," 1865, with the secondary number 191; no. 1540 from eastern Cuba, 1859; and "edge of savannas, Hanabana, May 19," in 1865, with the secondary number 190. Wright's 3877 in the Sauvalle Herbarium and in the Torrey Herbarium is part $P$. exiguiflorum.

11. Panicum distantiflorum Rich. in Sagra, Hist. Cub. 11: 304.1850.

Panicum utawanaeanum Scribn. in Millsp. Field Columb. Mus. Bot. 2: 25. 1900.

Panicum sintenisii Nash, Bull. Torr. Club 30 : 382. 1903.

Wright 3452; Cojimar, Baker HC 267, 2902, Hitchcock in 1906; Triscornia, Tracy 9089, Hitchcock in 1906; Matanzas, Rugel 190 in Gray Herbarium, 874 in Herb. N. Y. Bot. Gard.

Grisebach's specimen from eastern Cuba, 1860, is numbered " $104=3452$." Another specimen, included by Grisebach under Panicum stenodes, is labeled, "Bushy savannas, Hanabana, May 16, in small tufts," no. 285. A third specimen, "Savannas of Guamaroca, July 25," no. 284, is also included under P. stenodes. A part of Wright 3870 in the National Herbarium belongs to this species. The type of Richard's species in the herbarium of the Museum at Paris agrees with Scribner's type from Guanica, Porto Rico, ${ }^{a}$ a part of which is in the National Herbarium. Nash's description applies to these specimens and his type (Sintenis 3463 ) was also collected at Guanica, Porto Rico. Sintenis's 3365 and 3416, from Guanica, Porto Rico, also belong to this species.

12. Panicum divaricatum L. Syst. Nat. ed. 10. 2: 871. 1759.

Panicum bambusoides Hamilt. Prod. Ind. Occ. 10. 1826.

Panicum chauvinii Steud. Syn. Pl. Glum. 1: 68. 1854.

Hillsides, scandent or ascending, Valestina, September 19, Wright 748; Wright 747; Guanajay, Baker HC 4269, El Cangre, Baker HC 5198; Cojimar, Baker HC 5324, La Magdalena, Baker HC 2501, 4611; Habana, Baker HC 1837; Triscornia, Hitchcock in 1906; Herradura, Tracy 9047, 9044; Santiago de Cuba, Millspaugh 1015; Baracoa, Pollard, Palmer \& Palmer 76; Isle of Pines, Millspaugh 1422, Palmer \& Riley 1001; Cienfuegos, Combs 148 in Gray Herbarium. In the herbarium of the New York Botanical Garden are the following: Managua, Baker \& Wilson 304; Santiago de Cuba, Underwood \& Earle 1642; Taylor 327; Matanzas, Britton \& Wilson 241; Isle of Pines, Curtiss in 1904.

Widely clambering over bushes. The two specimens of this in Grisebach's herbarium, called by him $P$. divaricatum, are "Prope villam Monte Verde dictam, Cuba orientalis," no. 747, and another labeled $747 \alpha$. These are both smooth throughout. Besides these there are two specimens with pubescent blades, which Grisebach calls $P$. divaricatum variety puberulum.b One is labeled "In sylvis densis, Matanzas, Cuba, 
Rug. 187;"' the other is Wright 748 from eastern Cuba. The type collected by March in Jamaica is also here. Another specimen (Wright, western Cuba in 1863) is marked by Grisebach as $\beta$ stenostachyum. These last two specimens appear to be the ordinary form of $P$. divaricatum. The pubescent form can scarcely be separated even as a variety.

Hamilton's species is based on "P. bambusoides Herb. Prof. Desv. Porto Rico." A specimen so marked in the Desvaux Herbarium in the Museum at Paris is $P$. divaricatum. The type of $P$. chauvinii Steud. is also in the Museum at Paris.

13. Panicum erectifolium Nash, Bull. Torr. Club 23: 148. 1896.

Panicum sphaerocarpon floridanum Vasey, U. S. Dept. Agr. Div. Bot. Bull. 8: 33. 1889, not $P$. floridanum Trin. 1835.

Wright 3462.

The specimen in the Grisebach Herbarium is from western Cuba, 1862, and is numbered " $896=3462$." The specimen in the Gray Herbarium is labeled "Lagunas, Vueltabajo, July 24."

14. Panicum exiguiflorum Griseb. Cat. Pl. Cub. 234. 1866.

Panicum minutiflorum Rich. in Sagra, Hist. Cub. 11: 305. 1853, not Rasp. 1825.

Panicum tricolor Hack. Oesterr. Bot. Zeitschr. 51: 370. 1901.

Wright 755, 3450, 3877 in part, 756 in Gray Herbarium; Pinar del Rio, Earle \& Wilson HC 1550; Herradura, Tracy 9075, Hitchcock in 1906; La Magdalena Baker 1; Isle of Pines, Taylor 35. The following are in the Herbarium of the New York Botanical Garden: Isle of Pines, Taylor 35, Curtiss in 1904; Madruga, Shafer 452.

Wright's 3450 in the National Herbarium is labeled "Low savannas, Chirigote, Oct. 26;" the same number in the Gray Herbarium, "Pinales, Almacigos, July 26." The type in the Grisebach Herbarium is labeled "In bushy savannas, Hanabana, May 16," 1865. The type of Richard's species is at Paris. Grisebach has two other specimens of this, one from western Cuba, 1863, numbered " $909=3450$," which is the type of his $P$. laxum variety variegatum, ${ }^{a}$ and the other, also from western Cuba, numbered " $89=3450$." Wright's 755, "Pinales, San Juan de Buena Vista, Nov. 21, 1860-64," and no. 756, from eastern Cuba in 1856-57, both in the Gray Herbarium, are P. exiguiflorum.

The type of Panicum tricolor, Eggers 3978, from Fortune Island, Bahamas, was examined at Hackel's herbarium.

15. Panicum fasciculatum Sw. Prod. 22. 1788.

Panicum fuscum Sw. Prod. 23. 1788.

Panicum flavescens Sw. Prod. 23. 1788.

Panicum illinoniense Desv. Opusc. 91. 1831.

Santiago de las Vegas, Van Hermann HC 2445, Baker HC 2678, 5110, Wilson 593; La Magdalena, Baker HC 3636; Herradura, Tracy 9091; Cienfuegos, Pringle 74, 124, Combs 252 in Gray Herbarium; Rugel 881 in Gray Herbarium; Habana, Leon 573. In the herbarium of the New York Botanical Garden are the following: Santiago de Cuba, Taylor 28; Baracoa, Underwood \& Earle 839; Santiago de las Vegas, Van Hermann 2698b.

This appears to be a recent introduction into Cuba, where it occurs as a weed. The type specimens of Swartz's three species differ only as to size of panicle.

The specimen in the Grisebach Herbarium is from eastern Cuba in 1859 and is numbered 754. Wright's 754 in Gray Herbarium is from "Roadsides near Saltadero, Aug. 4," Monte Verde, 1859.

The published source of $P$. illinoniense Desv. is "America boreali." The specimen in Desvaux's herbarium in the Museum at Paris, marked with this name in Desvaux's handwriting, is $P$. fasciculatum Sw. The sheet is also marked "hab. Carol." The locality is clearly an error. 
16. Panicum fusiforme nom. nov.

Panicum neuranthum ramosum Griseb. Cat. PI. Cub. 232. 1866, not P. ramosum L. 1767.

Pine woods, Las Oblas, Pinar del Rio, September, Wright 3453 in part; Wright 3454 in part; Herradura, Tracy 9074, Hitchcock in 1906, Baker \& Dimmock HC 4846, Caldwell \& Baker 7139; Isle of Pines, Curtiss 406.

There has been much confusion in the specimens distributed by Wright unde numbers 3453,3454 , and 3461 . The Grisebach specimen of the above species, which is the type of his variety, is labeled "Cuba occ. Wr. 1863, 900=3454." No. 3453 is $P$. neuranthum. As distributed in various herbaria, however, $P$. fusiforme occurs in part of nos. 3453,3454, and 3461. With these are various mixtures of $P$. neuranthum, $P$. paucicitiatum, and $P$. lancearium.

17. Panicum geminatum Forsk. Fl. Aegypt. Arab. 18. 1775.

Panicum paspalodes Pers. Syn. 1: 81. 1805.

Panicum brizoides Lam. Tab. Encycl. 1: 170. 1791, not L. 1771.

Wright 761; Santiago de las Vegas, Hitchcock in 1906; Batabano, Hitchcock in 1906; Cienfuegos, Combs 426 in Gray Herbarium; Isle of Pines, Curtiss in 1904 in Herb. N. Y. Bot. Gard.

No. 761 of Wright in the National Herbarium is labeled "Wet, around ponds, Hanabana, June 5." The Grisebach specimen is from eastern Cuba in 1860 and is labeled "Bunches beside water holes. Palma Sola, July 19. 99=761." Persoon's name is based on Panicum brizoides Lam., as he quotes Lamarck's diagnosis and cites his name as synonym. At Florence there is an authentic specimen of this sent by Lamarck, collected in Mauritius by Commerson. The specimen of Panicum brizoides in the Linnæan Herbarium is Echinochloa colona (L.) Link. Doella takes up Paspalum appressum Lam. Tabl. Encycl. 176. 1791, transferring it to Panicum, but this is invalidated by Panicum appressum Forsk. Fl. Aegypt. Arab. 20. 1775, and by $P$. appressum Kunth, Enum. 1: 84. 1833.

\section{Panicum glutinosum Sw. Prod. 24. 1788.}

Panicum obtusiflorum Rich. in Sagra, Hist. Cub. 11: 305. 1850.

Panicum lindenii Griseb. Cat. Pl. Cub. 233. 1866.

Shady hills, Loma Pelada, December 12, Wright 757; Linden 2143 in Paris Herbarium. Wright's 757 in the Gray Herbarium is from "La Perla, along roadsides." The Grisebach specimen is from eastern Cuba, no. 757. P. lindenii Griseb. is a typonym of $P$. obtusiflorum Rich., both being based on Linden 2143, which is in the Paris Herbarium.

19. Panicum grisebachii Nash, Bull. Torr. Club 35: 301. 1908.

Mountain woods, creeping-assurgent, Valestina, October 8, Wright 3457; Madruga, Britton, Britton \& Shafer 758; San Antonio de lus Baños, Baker HC 2853, Hitchcock in 1906; Pinar del Rio, Baker HC 3817; Matanzas, Rugel 187 in Herb. N. Y. Bot. Gard.

The main stem creeps along the ground, throwing up flowering branches a foot or so high. There are two Wright specimens of this in the Grisebach Herbarium, both from western Cuba, 1863, one numbered " $889=3457$," the other " $941=3457$."

20. Panicum hirsutum Sw. Fl. Ind. Occ. 1: 173. 1797.

Wet ground near Matanzas, July 5, Wright 297 in 1865 in Grisebach Herbarium.

A large stout grass with hirsute sheaths, glabrous blades, large, rather compact panicle, and spikelets about $2 \mathrm{~mm}$. long, being similar to the type at Stockholm. In the herbarium of the New York Botanical Garden are two other West Indian specimens of this species: Martinique, Duss 768; Guadaloupe, Duss 3917.

$a$ In Mart. Fl. Bras. $2^{2}:$ 184. 1877. 


\section{Panicum hirtivaginum sp. nov.}

Culm erect (apparently from a perennial base), ascending-hirsute, 60 to $80 \mathrm{~cm}$. tall, the nodes densely hirsute; sheaths hirsute like the culms; ligule bristly; blades flat, hirsute on both surfaces or glabrescent, scarcely scabrous on the margins, elongated, erect or ascending, as much as $60 \mathrm{~cm}$. long, and $12 \mathrm{~mm}$. wide; panicle diffuse, 20 to $30 \mathrm{~cm}$. long, branches ascending, these and the main axis glabrous or somewhat scabrous; spikelets. on pedicels 1 to $3 \mathrm{~mm}$. long, ovate-acuminate, glabrous, about $3 \mathrm{~mm}$. long; lower glume ovate, strongly 5 -nerved, somewhat over $1 \mathrm{~mm}$. long; upper glume and sterile lemma equal, strongly 7 and 9-nerved, the palea of the latter delicate, about half as long; fertile lemma chartaceous, smooth, acute, nearly $2 \mathrm{~mm}$. long, inrolled at the margins and including the margins of the palea; fruit brown at maturity.

Type specimen Wright 758, Cuba, U. S. National Herbarium no. 559958. Other specimens are: Santiago de las Vegas, Tracy 9116; Habana, Tracy 9068; Wright 3860 in Gray Herbarium; Cienfuegos, Combs 259 in Gray Herbarium. In the herbarium of the New York Botanical Garden are: Santiago de Cuba, Hamilton 230; Alto Cedro, Underwood \& Earle 1611; Madruga, Britton \& Shafer 745; Eggers 5406.

Wright's 758 is listed in Sauvalle's Flora Cubana as P. rudgei Roem. \& Schult., which species apparently does not occur in Cuba. The two specimens of Wright 758 in the Sauvalle Herbarium are labeled "In low ground beside rivulets, savannas of Guamaroca, July 25," and "In fields, Retiro, Oct. 11." The Grisebach specimen of this species is numbered 281 and was collected in 1865 .

This species differs from $P$. hirsutum $\mathrm{Sw}$. in its smaller culms, hirsute blades, more diffuse panicle, and larger spikelets.

22. Panicum lancearium Trin. Clav. Agrost. 234. 1822.

Panicum nashianum Scribn. U. S. Dept. Agr. Div. Agrost. Bull. 7: 79.1897.

Wright 3460 ; Wright 3461 in part.

Wright's 3460 and 3461 in part, in the Krug and Urban Herbarium belong to this species. There is a specimen of this in the Grisebach Herbarium from eastern Cuba, numbered " $101=3460 "$ and labeled "Panicum dichotomum var. nodiflorum Lam. forma glabresc." Wright's 3460 in the Gray Herbarium is labeled "Pinal. San Juan de Buenavista, Nov. 21.",

23. Panicum laxum Sw. Prod. 23. 1788.

Panicum agrostidiforme Lam. Tabl. Encycl. 1: 172. 1791.

Panicum tenuiculmum Meyer, Prim. Fl. Esseq. 58: 1818.

Panicum polygonatum Schrad. in Schult. Mant. 2: 256. 1824.

Panicum diandrum Kunth, Rev. Gram. 2: 323. 1829.

Panicum ramuliflorum Hochst.; Steud. Syn. PI. Glum. 1: 65. 1854.

Wright '759, 3856, 3862 in part, 3863 in part; Santiago de Las Vegas, Tracy 9114, Hitchcock in 1906; Guanabacoa, Leon 190; Las Acostas, Baker HC 5240; Province Santa Clara, Baker HC 2477, 2482; Isle of Pines, Palmer \& Riley 1069, Taylor 37, Curtiss 464; Herradura, Hitchcock in 1906, Tracy 9059, 9062, 9072, 9099, Caldwell \& Baker 7136; Pinar del Rio, Baker HC 1699; Cienfuegos, Combs 321 in Gray Herbarium. The following are in the Herbarium of the New York Botanical Garden: Pinar del Rio, Shafer 323; Isle of Pines, Curtiss in 1904; Sagua, Britton \& Wilson 300; Guajay, Earle \& Wilson 343 .

Wright's 759 in National Herbarium is labeled "Savannas, Retiro, Oct. 11." There are four specimens in the Grisebach Herbarium: Western Cuba, collected in 1863, " $893=759$;" eastern Cuba, 1859, no. 759; "Hanabana, May 22, 1865, 189;" "Wetamong tall Cyperaceae, Hanabana, May 25, 1865, 196." Wright's 3862 in the Gray Herbarium consists of two specimens, one of which is $P$.laxum, the other $P$. condensum. Wright's 759 in the Gray Herbarium has three printed blank labels, for the years 185657,1859 , and $1860-64$. 
The type of $P$. agrostidiforme Lam. was examined at the Lamarck Herbarium in the Museum at Paris; those of $P$. polygonatum Schrad. and $P$. diandrum Kunth at Halle, among specimens loaned to Professor Mez by the Berlin Herbarium. A specimen of $P$.tenuiculmum from Meyer is in the Trinius Herbarium; the type of $P$. ramuliflorum Hochst. ("Pl. Kappler surin. nr. 1523") is in the Herbarium at Munich. All these agree with Swartz's type.

24. Panicum leucothrix Nash, Bull. Torr. Club 24: 41. 1897.

Herradura, Hitchcock in 1906.

In the Grisebach Herbarium is a specimen of this from western Cuba, 1863, numbered " $923=3463$." For other species distributed as 3463 , see $P$. wrightianum, P. tenue, and $P$. caerulescens.

25. Panicum maximum Jacq. Coll. 1: 76. 1786.

Panicum laeve Lam. Tabl. Encycl. 1: 172. 1791.

Panicum trichocondylum Steud. Syn. P1. Glum. 1: 74. 1854.

Santiago de las Vegas, Wilson 438, Baker \& Wilson 682, Hitchcock in 1906; Madruga, Shafer; Guanabacoa, Leon 189; Guanajay, Palmer \& Riley 816; San Diego de los Baños, Palmer \& Riley 542, 545; El Guama, Palmer \& Riley 178; Pinar del Rio, Wilson 1770, Palmer \& Riley 377; Herradura, Hitchcock in 1906; Santiago de Cuba, Pollard, Palmer \& Palmer 283; Cienfuegos, Combs 294 in Gray Herbarium; Guines, Leon 427. In the Herbarium of the New York Botanical Garden are: Santiago de Cuba, Underwood \& Earle 162; Matanzas, Britton \& Shafer 113.

The type of $P$. laeve Lam., labeled "de Ste. Dominique" in the Lamarck Herbarium and that of $P$. trichocondylum Steud., labeled "Ins. Guadaloup. Duchaissing" are in the Museum at Paris.

Cultivated for forage and frequently escaped into waste land.

26. Panicum megiston Schult. Mant. 2: 248. 1824.

Panicum altissimum Meyer, Prim. Fl. Esseq. 63. 1818, not Brous. 1805.

On tembladeros in lagunas, St. Cruz de los Piños, July, Wright 3872.

27. Panicum neuranthum Griseb. Cat. P1. Cub. 232. 1866.

Wright 3453 in part.

The type specimen in the Grisebach Herbarium is from eastern Cuba, 1860, numbered "103=3453." The specimen in the Gray Herbarium is labeled, "Cuchillos de Baracoa, June 20." This species is distinguished from others of the Angustifolium group by the smooth culms and nodes, involute blades, and narrow panicles, and by spikelets $2 \mathrm{~mm}$. long. $P$. neuranthum also occurs in southern Florida: Sanibel Island, Simpson 298; Braidentown, Tracy 6711; Clearwater, Tracy 7166; Rugel 290; Miami, Hitchcock 705, 710; Alligator Harbor, Tracy 7176.

28. Panicum nitidum Lam. Tabl. Encycl. 1: 172. 1791.

Panicum subbarbulatum Scribn. \& Merr. U. S. Dept. Agr. Div. Agrost. Circ. 29: 9. 1901. Wright 3459.

The specimen in the Sauvalle Herbarium is fragmentary, but the specimen in the Kew Herbarium is more complete. Wright's 3459 in the Gray Herbarium is partly this and partly $P$. parvifolium.

29. Panicum numidianum Lam. Tabl. Encycl. 1: 172. 1791.

Panicum barbinode Trin. Mem. Acad. Petersb. VI. 32: 256. 1835.

Panicum equinum Salzm.; Steud. Syn. Pl. Glum. 1: 67. 1854.

Wet places in savannas, Pinar del Rio, October, Wright 1545; Puentes Grandes, Leon 283; Cienfuegos, Pringle 26, Habana, Leon 568. The following are in the herbarium of the New York Botanical Garden: Santiago de Cuba, Underwood \& Earle 163; Matanzas, Britton \& Shafer 512; Eggers 4870. 
The Grisebach specimen is from eastern Cuba, 1859, no. 1545. This species has been referred to $P$. molle $\mathrm{Sw}$., but the latter is a quite different Brazilian species. It may be that $P$. muticum Forsk $a$ is an older name for this species.

Salzmann's specimen from Bahia, upon which Panicum equinum is based, is in the herbarium of Professor van Heurck at Antwerp; a duplicate is in the herbarium at Florence. The specimen from Reugger, Paraguay, also cited by Steudel, is in the herbarium of the Museum at Paris, and also belongs to this species.

30. Panicum parvifolium Lam. Tabl. Encycl. 1: 173. 1791.

Wright 3458; Herradura, Tracy 9060, 9079, Hitchcock in 1906, Shafer; Pinar del Rio, Shafer 430 in Herb. N. Y. Bot. Gard.

The Grisebach specimens are from western Cuba, 1863, numbered, " $901=3458$ " and "927=3458." This is listed by Grisebach $b$ as $P$. cyanescens. The type of $P$. parvifolium is in the Lamarck Herbarium at Paris. Wright 3458 in the Gray Herbarium is labeled "In lagunas (ponds) Los Almacigos, July 28," and "On tembladeros in lagunas, Asiento Viejo de San Julian, Nov."

31. Panicum pauciciliatum Ashe, Journ. Elisha Mitch. Soc. 16: 87. 1900.

On crumbling banks, Loma Pelada, November 20, Wright 3876.

There is some material of this species mixed with Wright 3461 in the Krug and Urban Herbarium. This species occurs also in Porto Rico (Heller \& Heller 982b, 639, Underwood \& Griggs 955), and is common in the Atlantic coastal plain of the southern United States.

32. Panicum pilosum Sw. Prod. 22. 1788.

Panicum distichum Lam. Encycl. 4: 731. 1797.

Panicum pilisparsum Meyer, Prim. Fl. Esseq. 57. 1818.

Wright 3457; Herradura, Van Hermann HC 763, Tracy 9063; Isle of Pines, Curtiss 305, Taylor 36 in Gray Herbarium.

There seems to be an error in the number of the Wright specimen. It is published as 3451 in Grisebach's catalogue and in Flora Cubana, and the specimen is so numbered in the Kew and the Grisebach herbaria, but in the Sauvalle and the Berlin herbaria the number is 3457 . The Grisebach specimen is from western Cuba, 1863, numbered " $888=3451$."

The hairs on the rachis are variable. Curtiss's 305 in the National Herbarium is without hairs; the same number in the herbarium of the Cuba Experiment Station has hairs on some of the spikes. Wright's 3451 in the Gray Herbarium is from "Retiro, July 15, in woods (damp)."

33. Panicum polycaulon Nash, Bull. Torr. Club 24: 200. 1897.

Wright 3875 in National Herbarium; Herradura, Hitchcock in 1906; Shafer 480 in Herb. N. Y. Bot. Gard.; Isle of Pines, Palmer \& Riley 990.

34. Panicum repens L. Sp. Pl. ed. 2. 87. 1762.

Habana, Leon 296, 563.

35. Panicum reptans L. Syst. Nat. ed: 10. 2: 870. 1759.

Panicum grossarium L. op. cit. 871.

Panicum caespitosum Sw. Fl. Ind. Occ. 1: 140. 1797.

Panicum prostratum Lam. Tabl. Encycl. 1: 171. 1791.

Panicum insularum Steud. Syn. Pl. Glum. 1: 160. 1854.

Wright 762, 763, 3857; Habana, Leon 276, 292, 297, 566, 576, Curtiss 691, Hitchcock in 1906; San Antonio, Hitchcock in 1906; Baracoa, Pollard, Palmer \& Palmer 19; Madruga, Curtiss 536; Colon, Baker HC 3588; Herradura, Tracy 9103; Cienfuegos, Pringle 73; Combs 253 in Gray Herbarium; Yumury Valley, Rugel 1985 in Gray Herbarium. The following are in the herbarium of the New York Botanical Garden: La Magdalena, Earle \& Baker 2455; Baracoa, Underwood \& Earle 1391; Yumury Mountains, Rugel 195.

( Fl. Aegypt. Arab. 20. 1775.

$b$ Cat. Pl. Cub. 233. 1866.

61170 -vol 12 , PT $6-09-4$ 
The Grisebach specimen from eastern Cuba, 1860, is numbered " $105=762$." The types of the above synonyms are all identical. $a$ The West Indian grass commonly known as $P$. grossarium is $P$. adspersum Trin.

The type of Panicum insularum Steud. labeled "Antillae minores, Hohenacker" is in the Museum at Paris.

36. Panicum rugelii Griseb. Cat. Pl. Cub. 233. 1866.

Shady woods, Valestina, September 27, Wright 3465; Pinar del Rio, Baker HC 3790; San Antonio, Hitchcock in 1906; Matanzas, Britton \& Shafer 106 in Herb. N. Y. Bot. Gard.

Creeping flat along the surface of the ground in shady woods, the leaves distinctly dorso-ventral, more or less pubescent. In the Grisebach Herbarium is Rugel 188 from Matanzas, the type specimen, and Wright 3465. A duplicate type is in the Gray Herbarium.

37. Panicum scoparium Lam. Encyc1. 4: 444. 1797.

Panicum viscidum Ell. Bot. S. C. \& Ga. 1: 123. 1816.

Wright 3467.

The specimen with this number in the Grisebach Herbarium is the same. The specimen in the Gray Herbarium is labeled "In loose bunches, road to Pinal Mayarí, Aug. 4."

38. Panicum sellovii Nees, Agrost. Bras. 153. 1829.

Panicum lasianthum Trin. Icon. 245. 1835.

Panicum valenzuelanum Rich. in Sagra, Hist. Cuba 11: 304. 1850.

Wet savannas, Hanabana, May 17, Wright 3462; Wright 3455; edge of thickets in pinales, Pinar del Rio, September, Wright 3855; Shafer 561 in Herb. N. Y. Bot. Gard.; Herradura, Tracy 9098, Hitchcock in 1906.

Grisebach's specimen, which is from western Cuba, 1863, and is numbered " $935=$ 3455 ," is the type of $P$. rugulosum hirtiglume Griseb. $b$ Wright's 3855 in the Sauvalle Herbarium has a second label which reads, "Low, wet ground beside rivulets, Pinar del Rio, Oct." Wright's 3455 in the Gray Herbarium is labeled "Pinales, La Catalina, Sept. 11," and "Pinal, Rangel, Aug. 6." P. rugulosum Trin.c has glabrous spikelets. This has not been found in Cuba. The type of $P$. sellovii in the Berlin Herbarium agrees with the type of $P$. lasianthum in the Trinius Herbarium. In the latter herbarium is also a portion of the type of $P$. sellovii. The type of Richard's species is at Paris.

39. Panicum sloanei Griseb. Fl. Brit. W. Ind. 551. 1864.

Hillsides, scandent or trailing, Valestina, September 27, Wright 3878; near Habana, Britton \& Shafer 115, 759, Guanajay, Baker HC 4587, 4592; San Antonio, Hitchcock in 1906; Cienfuegos, Combs 55 in Gray Herbarium; Rugel 872 in Gray Herbarium. The following are in the herbarium of the New York Botanical Garden: Matanzas, Britton \& Wilson 121,393; Rugel 868; Santiago de Cuba, Taylor 328; Madruga, Britton \& Shafer 759; Isle of Pines, Taylor 22.

Leaf blades larger and broader and panicle larger and more widely spreading than in $P$. divaricatum. In the Grisebach Herbarium are two specimens, "In sylvis densis, Matanzas, Rugel 872," and "Woods, Hanabana, June 17, 1865," Wright 269. A specimen in the herbarium of the New York Botanical Garden from Matanzas (Britton $\&$ Shafer 586) is doubtfully referred here.

a For a discussion see Contr. Nat. Herb. 12: 119. 1908.

$b$ Cat. Pl. Cub. 233. 1866.

$c$ Gram. Pan. 195. 1826.

$61170-09-15$ 
40. Panicum stenodes Griseb. Fl. Brit. W. Ind. 547. 1864.

Low, wet pine woods, El Salado, August, Wright 3871; Herradura, Hitchcock in 1906, Baker \& Abarca HC 4192, Baker HC 2956, Habana, Leon 567; Isle of Pines, Curtiss in 1904 in Herb. N. Y. Bot. Gard.

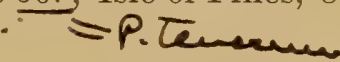

The Grisebach specimen is labeled "Sandy ground in the Cienaga, Hanabana, May 17," no. 192. Two other specimens, 284 and 285, included by Grisebach in this cover, are $P$. distantiflorum. $P$. caricoides Nees $a$ differs in having larger spikelets ( $2 \mathrm{~mm}$. long) with bristles at apex of pedicel, and flat blades, villous on upper surface, as shown by the type in the Munich Herbarium and a portion in the Trinius Herbarium.

41. Panicum strigosum Muhl.; Ell. Bot. S. C. \& Ga. 1: 126. 1816.

Savannas around base of palms, Daganiguas, September, Wright 3875; El Guama, Palmer \& Riley 213.

Wright's 3875 in the National Herbarium is $P$. polycaulon.

42. Panicum swartzianum Hitchc. Contr. Nat. Herb. 12: 140. 1908

Panicum lanatum Sw. Prod. 24. 1788, not Rottb. 1776.

Santiago de Cuba, Hamilton 218 in Herb. N. Y. Bot. Gard.

43. Panicum tenerum Beyrich; Trin. Mem. Acad. Petersb. VI. 3: 341.1835.

In dense bunches in dried-up ponds, Pinar del Rio, December, Wright 188; Herradura, Baker \& Dimmock HC 4837, Hitchcock in 1906, Tracy 9080; "a tall branching grass in deepish water of lagunas, Pinar del Rio, Sept.,". Wright 3870 in National Herbarium.

Wright's 188 is mixed with $P$. distantiflorum and has, in addition to the label quoted, another, "Savannas of Guamaroca, July 28." Wright's 3870 is also mixed with $P$. distantiflorum. The Florida specimens of $P$. tenerum have been going under the name of $P$. stenodes. Wright's 3860 in the Gray Herbarium is $P$. tenerum.

44. Panicum tenue Muhl. Gram. 118. 1817.

Panicum albomarginatum Nash, Bull. Torr. Club 24: 40. 1897.

Sandy pine woods, Pinar del Rio, September, Wright 3463 in part; Herradura, Shafer 560, Baker HC 2967, 2973, 2977, Hitchcock in 1906; Pinar del Rio, Shafer 320 in part; Isle of Pines, Taylor 32.

For other specimens distributed as Wright 3463, see P. caerulescens, P. leucothrix, and $P$. wrightianum.

45. Panicum tricanthum Nees, Agrost. Bras. 210. 1829.

Wright 753; Habana, Curtiss 598; Vento, Leon 557.

No. 753 of Wright in the National Herbarium is labeled "In large, loose bunches beside the river Agabama Guinia, Trinidad, May 5." The specimen in the Grisebach Herbarium is from western Cuba, 1863, and is numbered " $948=753$." In the Gray Herbarium there are two specimens, "Villa Clara, Macagua, Jan. 21," 1860-64, and "Santa Isabel, along rivulets," eastern Cuba, in 1856-57.

46. Panicum trichoides Sw. Prod. 24. 1788.

Prope villam Monte Verde dictam, Cuba Orientali, 1859, Wright 1538, in Gray Herbarium; Habana, Curtiss 714, Britton \& Wilson 510; Guanabacoa, Leon 206.

A weed in cultivated soil. P. brevifolium L., to which our species has been referred, is from India ( $P$. ovalifolium Poir. as described in Hooker's Flora of British India).

47. Panicum virgatum cubense Griseb. Cat. Pl. Cub. 233. 1866.

Panicum virgatum obtusum Wood, Bot. \& Flor. 392. 1874.

Panicum virgatum breviramosum Nash, Bull. Torr. Club 23: 150. 1896. 
Marshes, Hanabana, May 27, Wright 3873; Batabano, Baker HC 2763, Hitchcock in 1906, Palmer \& Riley 1134.

Wright's specimen in the Sauvalle Herbarium has also the secondary number 183. In the Grisebach Herbarium this occurs with the number 183 and is labeled Panicum virgatum variety cubense, "Low savannas, Hanabana, May 19." This form is characterized by the more obtuse spikelets, narrower panicle, and culms solitary or few in a clump.

48. Panicum wrightianum Scribn. U. S. Dept. Agr. Div. Agrost. Bull. 11: 44. 1898.

Panicum minutulum Desv. Opusc. 87. 1831, not Gaud. 1826.

Wright 3463 in National Herbarium.

There is a specimen of this species in the Grisebach Herbarium from western Cuba, 1863 , numbered " $895=3463$," and bearing the note "Spiculis puberulis." Wright's 3463 in the Boissier and in the Kew Herbarium consists of this species and P. leucothrix. It is to be noted that $P$. tenue and $P$. caerulescens are also distributed in various herbaria as Wright 3463. Wright's 3463 in the Gray Herbarium is labeled "Lagunas, Vueltabajo, July 24." The sheet also bears a small plant of $P$. leucothrix.

49. Panicum zizanioides H. B. K. Nov. Gen. \& Sp. 1: 100. 1816.

Panicum oryzoides Sw. Prod. 23. 1788, not Ard. 1764.

Wright 3466; Laguna Castellano, Baker HC 4335.

Grisebach's specimen of Wright 3466 is also without locality.

33. ICHNANTHUS Beauv. Agrost. 56. pl. 12.f. 1. 1812.

Blades, especially those of sterile shoots, contracted into petiole-like

bases, as much as $1 \mathrm{~cm}$. long........................... I. wrightii.

Blades not contracted into petiole-like bases.

First glume as long as spikelet; stem creeping, blades ovate.....2. I. nemorosus.

First glume one-half to three-fourths as long as spikelet; stem ascending.

Blades narrowly linear-lanceolate, thick and firm........... I. mayarensis. Blades ovate-lanceolate, thin, usually 10 to $15 \mathrm{~mm}$. wide...3. I. pallens.

1. Ichnanthus mayarensis (Wright).

Panicum mayarense Wright, Anal: Acad. Cienc. Habana 8: 206. 1871; Sauv. Fl. Cub. 197.

Pinales de Mayarí, July 24, and Mayarí Abajo, August 2 (1860-64), Wright 3468 in Gray Herbarium.

This species is represented by two sheets, as noted above, the second of which, marked Mayari Abajo, is the type, as this locality agrees with that published. This number has been found in no other herbarium. The fertile lemma is slightly over $2 \mathrm{~mm}$. (2.2 mm.) long, and the margins do not meet except at the tip, thus exposing a narrow strip of the palea. The scars at the base are small and the wings are wanting.

2. Ichnanthus nemorosus (Sw.) Doell in Mart. FI. Bras. 2²: 289. 1877.

Panicum nemorosum Sw. Prod. 22. 1788.

In dense woods, Retiro, November 20, Wright 3881; damp woods near the Mogote de Mono, October 8, Wright 3882; shady banks of Rio Sico in Arroyo Hondo, Pinar del Rio, December, Wright 3858.

3. Ichnanthus pallens (Sw.) Munro; Benth. Fl. Hongk. 414. 1861.

Panicum pallens Sw. Prod. 23. 1788.

Wright 750; El Guama, Palmer \& Riley 130,.218; Baracoa, Pollard, Palmer \& Palmer 15. The following are in the herbarium of the New York Botanical Garden: Santiago de Cuba, Taylor 385, 526, Hamilton 215; Baracoa, Underwood \& Earle 267; El Sigual, Eggers 4661. 
There are four specimens of this in the Grisebach Herbarium: No. 750 labeled "Prope villam Monte Verde dictam. Cuba orientali;" another numbered 750 from eastern Cuba, 1856-57; a Wright specimen without number or locality collected in 1860-64; and a specimen with proliferous spikelets, numbered 887, "Cuba occ. Wr. 1863." This species not infrequently occurs with proliferous spikelets, as in Palmer \& Riley 130 cited above. The spikelets then consist of many sterile lemmas and the plants appear as if belonging to the tribe Festuceae.

4. Ichnanthus wrightii sp. nov.

Culms slender, prostrate-spreading, more or less rooting at the nodes, glabrous or sparsely villous, 20 to $30 \mathrm{~cm}$. long; sheaths mostly less than half the length of the internodes, striate-nerved, villous on the margins, otherwise glabrous or nearly so; blades ovate-lanceolate, striate-nerved, faintly 3 to 5-ribbed, glabrous, 12 to $30 \mathrm{~mm}$. long, 2 to $8 \mathrm{~mm}$. wide on the sterile shoots, somewhat larger and thicker on the ascending flowering culms, all abruptly or cordately narrowed into a slender stalk 1 to $5 \mathrm{~mm}$. long on the fertile culms, or as much as $15 \mathrm{~mm}$. long on the sterile shoots; panicles 4 to $8 \mathrm{~cm}$. long, consisting of a few spike-like racemes, 0.5 to $2 \mathrm{~cm}$. long; spikelets $3 \mathrm{~mm}$. long, glabrous, the pedicel minutely pubescent; lower glume about half the length of the spikelet, 3-nerved; second glume and sterile lemma equal, acuminate, strongly 5-nerved; fertile lemma scarcely $2 \mathrm{~mm}$. long, the edges meeting and covering the palea, except at the very base, the outer margin of the base of the lemma bearing a scar at each side, but no wings.

Wright's 3880 . U.S. National Herbarium no. 559959 of this collection is the type. The specimen in the Sauvalle Herbarium is labeled, "Under overhanging rocks (damp) and around base of palms beside the Rio Seco in Arroyo Honda, Pinar del Rio, Dec." The Grisebach specimen consists of a single spikelet in a packet, labeled "Echinolaena Sp." no. 760. In the Kew Herbarium there are four specimens numbered 2, 23, 244, 760. Nos. 760 and 3880 are also in the Gray Herbarium. This species is allied to $I$. mayarensis.

34. TRICHOLAENA Schrad. in Schult. Mant. 2: 163. 1824.

1. Tricholaena rosea Nees, Cat. Sem. Hort. Vratisl. 1835.

Britton, Britton \& Shafer 533.

Sparingly introduced.

35. OPLISMENUS Beauv. Fl. Owar. 2: 14.t.58. 1804

1. Oplismenus hirtellus (L.) Roem. \& Schult. Syst. 2: 481.1817.

Panicum hirtellum L. Syst. Nat. ed. 10. 2: 870. 1759.

Panicum setarium Lam. Tabl. Encycl. 1: 170. 1791.

Woods, Hanabana, June 1, Wright 1543; damp woods, Monte Verde, March, Wright 751; Santiago de las Vegas, Baker HC 5051, Hitchcock in 1906; San Antonio, Hitchcock in 1906; Guanajay, Baker HC 3461; Habana, Curtiss 593, Leon 556; Matanzas, Palmer \& Riley 12; Cienfuegos, Pringle 76; Combs 667 in Gray Herbarium; El Guama, Palmer \& Riley 146; Isle of Pines, Curtiss 268; Matanzas, Rugel 189 in Gray Herbarium. In the herbarium of the New York Botanical Garden are the following: Matanzas, Britton \& Shafer 221; Santiago de Cuba, Taylor 422, 481.

Wright's numbers 751 and 1543 in the Grisebach Herbarium are from eastern Cuba, 1859. The latter is numbered 1593 in Sauvalle's Flora Cubana.

- It is quite possible that the specimens here included may be referred to distinct species. The type of Panicum setarium Lam. at Paris resembles Wright's 1543. The blades are short and the clusters of spikelets globose and few-flowered: Wright 751 and Curtiss 268 and 593 have larger and longer blades and spikes, but some of the other specimens are intermediate.
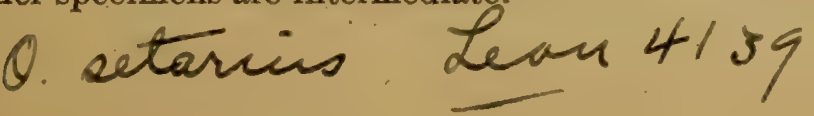
36. ChaEtochloA Scribn. U. S. Dept. Agr. Div. Agrost. Bull. 4: 38. 1897.

Bristles retrorsely barbed; plant annual..................... . C. verticillata.

Bristles antrorsely barbed; plants perennial.

Culms pilose.

Culms glabrous.

Inflorescence dense and spike-like; involucral bristles 5

or more.

Bristles scarcely exceeding the spikelets; racemes slender............................... C. purpurascens.

Bristles 2 to 4 times as long as spikelets; racemes thick.................................. C. imberbis.

Inflorescence comparatively loose; involucral bristles 1 to 3 .

First glume 5-nerved, second 9 to 11 -nerved......... C. onurus.

First glume 3-nerved, second 5-nerved............5. C. setosa.

1. Chaetochloa hispida Scribn. \& Merr. U. S. Dept. Agr. Div. Agrost. Bull. 21: 25. 1900.

Sandy pine woods, La Grija, Nueva Filipina, January, Wright in 1865, in the Gray Herbarium.

2. Chaetochloa imberbis (Poir.) Scribn. U. S. Dept. Agr. Div. Agrost. Bull. 4: 39. 1897.

Panicum imberbe Poir. Encycl. Suppl. 4: 272. 1817.

Savannas, Chirigote, June 13, Wright 3472, 3473; Santiago de las Vegas, Baker HC 518, 561, 636, 1358, Hitchcock in 1906; Habana, Curtiss 749, Leon 269, Tracy 9112; San Diego de los Baños, Palmer \& Riley 546; Herradura, Baker HC 2965, Hitchcock in 1906; Isle of Pines, Taylor 45. The following are in the herbarium of the New York Botanical Garden: Matanzas, Britton \& Wilson 170, Britton \& Shafer 244; Sagua, Britton \& Wilson 319; Madruga, Shafer 454.

The species of Chaetochloa here considered are accepted as defined by Scribner and Merrill.a I have not seen the type of Panicum imberbe Poir. nor of Panicum geniculatum Lam., which may be an older name for the same.

In the Grisebach Herbarium are the following Wright specimens: 1. "Wet ground around lagunas, Hanabana, May 16," no. 199 of 1865, a prostrate bunch with culms 15 to $20 \mathrm{~cm}$. long. The bristles are only a little longer than the spikelets, the spikes about $1 \mathrm{~cm}$. long, the blades without the scattered long hairs on the upper surface found in most of the specimens. 2. No. 200 of 1865, which Grisebach has labeled Setaria glauca $\alpha$. This also has short bristles. 3. No. 3472, 1860-64, bristles short. 4. No. 3473, 1860-64, bristles about $5 \mathrm{~mm}$. long.

2a. Chaetochloa imberbis penicillata (Nees) Scribn. \& Merr. U. S. Dept. Agr. Div. Agrost. Bull. 21: 11. 1900.

Panicum penicillatum Nees, Agrost. Bras. 242. 1829.

Matanzas, July 7, Wright 3888; Santiago de las Vegas, Baker 522, 1276; Guines, Leon 428.

This differs from $C$. imberbis chiefly in having longer bristles.

3. Chaetochloa onurus (Wiŕd.) Scribn. \& Merr. U. S. Dept. Agr. Div. Agrost. Bull. 21: 27.1900 .

Panicum onurus Willd.; Nees, Agrost. Bras. 251. 1829, as synonym.

Setaria onurus Griseb. Fl. Brit. W. Ind. 555. 1864.

Wright 3474; Wright 182; Wright 3887 in National Herbarium (3487 in Sauv. Fl. Cub.); Triscornia, Tracy 9090; Cienfuegos, Combs 264 in Gray Herbarium. The following are 
in the herbarium of the New York Botanical Garden: Santiago de Cuba, Taylor 232; Madruga, Shafer 453; Matanzas, Britton \& Wilson 29.

In the Grisebach Herbarium are two Wright specimens of this species, "Savannas of Guanacaro, July 28," no. 287 of 1865, and no. 3474 of 1860 to 1864.

4. Chaetochloa purpurascens (H. B. K.) Scribn. \& Merr. U. S. Dept. Agr. Div Agrost. Bull. 21: 13. 1900.

Setaria purpurascens H. B. K. Nov. Gen. \& Sp. 1: 110̀. 1816.

Batabano, Shafer 487; Jaguey, Eggers 5320 in Herb. N. Y. Bot. Gard.

5. Chaetochloa setosa (Sw.) Scribn. U. S. Dept. Agr. Div. Agrost. Bull. 4: 39. 1897.

Panicum setosum Sw. Prod. 22. 1788.

Isle of Pines, Palmer \& Riley 1000 in Herb. N. Y. Bot. Gard.; Santiago de Cuba, Taylor 13, 71; Matanzas, Rugel 880.

\section{Wr. $38>9$ P.p. in Nac. H6,}

6. Chaetochloa verticillata (L.) Scribn. U. S. Dept. Agr. Div. Agrost. Bull. 4: 39. 1897.

Panicum verticillatum L. Sp. Pl. ed. 2. 82. 1762.

Habana, Curtiss 693, Hitchcock in 1906, Baker, HC 2675, Leon 555.

A weed in the Botanical Garden.

\section{CENCHRUS L. Sp. Pl. 1049. 1753.}

Blades crowded, short, stiff, conspicuously distichous.........2. C. distichophyllus. Blades not crowded, stiff, nor distichous.

Basal bristles of bui stout.......................... C. carolinianus.

Basal bristles of burs numerous, slender.

Burs $12 \mathrm{~mm}$. or more wide, lobes erect................ C. echinatus.

Burs not over $8 \mathrm{~mm}$. wide, lobes interlocking.......... C. viridis.

1. Cenchrus carolinianus Walt. Fl. Car. 79. 1788.

Cenchrus tribuloides L. err. det. Griseb. Fl. Brit. W. Ind. 556. 1864.

Cojimar, Hitchcock in 1906; Triscornia, Hitchcock in 1906; Guanajay, Palmer \& Riley 781; Habana, Palmer \& Riley 1146; Wright 3476 in Gray Herbarium.

2. Cenchrus distichophyllus Griseb. Cat. Pl. Cub. 234. 1866.

Wright 3475 .

The Grisebach specimen, which is the type of this species, is from western Cuba, 1863 , numbered " $916=3475$." Wright's 3475 in the Gray Herbarium is from "Pinales, Guanes, Remates, Dec."

3. Cenchrus echinatus L. Sp. Pl. 1050. 1753.

Santiago de las Vegas, Hitchcock in 1906; Guanajay, Palmer \& Riley 679; Isle of Pines, Taylor 24; Santiaga de Cuba, Taylor 24 in Herb. N. Y. Bot. Gard.

4. Cenchrus viridis Spreng. Syst. 1: 301. 1825.

Wright 3889; Guanajay, Palmer \& Riley 665; Santiago de Cuba, Millspaugh 1110, Pollard, Palmer \& Palmer 284; Wright 3476 in Grisebach Herbarium; Cienfuegos, Combs 597 in Gray Herbarium. The following are in the herbarium of the New York Botanical Garden: Matanzas, Britton \& Shafer 127; Santiago de Cuba, Underwood \& Earle 168. Wright 3889 is listed in Sauvalle's Flora Cubana as "Andropogon Sp.?" It would seem that there must be some error in numbering, but this number in the Gray Herbarium is also Cenchrus.

Cenchrus viridis may be distinguished from $C$. echinatus by the smaller burs and more incurved involucre lobes.

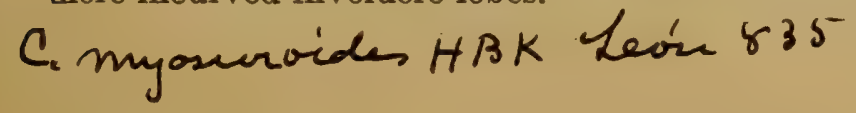


38. PENNISETUM Rich. in Pers. Syn. 1: 72 . 1805. $a$

Spike loose; bristles all naked ......................... $P$. domingense. Spike narrow, dense; some of the bristles plumose.............. . P. setosum.

1. Pennisetum domingense (Spreng.) Spreng. Syst. 1: 302.1825.

Gymnothrix domingensis Spreng.; Schult. Mant. 2: 284. 1824.

Eastern Cuba, Wright 1547 in 1857 in the Grisebach and Gray herbaria.

2. Pennisetum setosum (Sw.) Rich. in Pers. Syn. 1: 72. 1805.

Cenchrus setosus Sw. Prod. 26. 1788.

In thickets skirting pine woods, Pinar del Rio; Wright 3471.

The Grisebach specimen is from eastern Cuba, numbered " $111=3475$." Wright's 3471 in the Gray Herbarium is labeled "Edge of savannas, San Juan de Buenavista, Nov. 24."

39. CHAEtiUM Nees, Agrost. Bras. 269. 1829.

1. Chaetium cubanum (Wright).

Perotis? cubana Wright, Anal. Acad. Cienc. Habana 8: 288. 1871; Sauv. Fl. Cub.202. Wright 735 in Gray Herbarium.

The locality is not indicated except that the collection was made in eastern Cuba in 1856-57. This is referred by Doellb to Panicum chaetium Steud. (Chaetium festucoides Nees), but it differs in many respects. The blades are short and narrow, mostly involute; the inflorescence is loose, the spikelets few and distant, narrowed to a pedicel $1.5 \mathrm{~mm}$. long, strongly bearded at the base; first glume very narrow, $22 \mathrm{~mm}$. long including awn, 3-nerved at base; second glume 5 -nerved, $18 \mathrm{~mm}$. long, including awn; sterile lemma and fertile lemma thin, 3-nerved, awnless, $4.5 \mathrm{~mm}$. long.

40. PARATHERIA Griseb. Cat. Pl. Cub. 236: 1866.c

1. Paratheria prostrata Griseb. Cat. Pl. Cub. 236. 1866.

Panicum leptochyrium Doell in Mart. Fl. Bras. 2 ${ }^{2}$ : 150. 1877.

Wright 3906; Isle of Pines, Curtiss 461.

The Grisebach specimen, which is the type, bears the secondary number 207, and was collected in 1865. This is listed in Sauvalle's Flora Cubana as Chamaeraphis parvigluma Munro, a nomen nudum, and the Wright number is misprinted 3909. In the Gray Herbarium is a specimen of this species from Santarem, Pará, collected by Spruce, which agrees with Curtiss 461 in being more pubescent than the Wright specimen. This appears to be a duplicate type of Panicum leptochyrium Doell, though the specimen is not numbered.

41. STENOTAPHRUM Trin. Fund. Agrost. 175. 1820.

1. Stenotaphrum secundum (Walt.) Kuntze, Rev. Gen. Pl. 2: 794. 1891.

Ischaemum secundum Walt. Fl. Car. 249. 1788.

Wright 3490; Santiago de las Vegas, Baker HC 443, 794, 3649; Matanzas, Britton \& Shafer 140; Guanabacoa, Baker \& Hasselbring 7200; San Antonio, Hitchcock in 1906; Habana, Palmer \& Riley 822; Cape Corrientes, Millspaugh 1459; Cabañas, Palmer \& Riley 759; Isle of Pines, Palmer \& Riley 1008, Rowlee 49; Cienfuegos, Combs 535 in Gray Herbarium. The following are in the herbarium of the New York Botanical Garden: Batabano, Shafer 158; Isle of Pines, Curtiss in 1904.

The Grisebach specimen was collected in 1860-64.

$a$ In this genus I have followed Leeke, Zeitschr. Naturw. 79. 1907.

b In Mart. Fl. Bras. 2²: 150. 1877.

cThis genus is referred to Chamaeraphis R. Br. by Hackel (Engl. \& Prantl, Pflanzenfam.) but seems sufficiently distinct. 
42. OLYRA L. Syst. Nat. ed. 10. 2: 1261. 1759

1. Olyra latifolia L. Syst. Nat. ed. 10. 2: 1261. 1759.

Retiro, February 27, Wright 746; Las Acostas, Baker HC 5239; Vento, Baker HC 584; Lomas de Candelaria, Baker HC 1624; Madruga, Shafer; Baracoa, Pollard, Palmer \& Palmer 53; Cienfuegos, Pringle 70; El Guama, Palmer \& Riley 115, 216; Herradura, Baker HC 2940, Hitchcock in 1906; Isle of Pines, Palmer \& Riley 1058, 1066, Curtiss 293, Taylor 26, 27, in Gray Herbarium; Yumury Mountains, Rugel 186 in Gray Herbarium; Cienfuegos, Combs 210 in Gray Herbarium; Marianao, Leon 583. The following are in the herbarium of the New York Botanical Garden: Cedro, Underwood \& Earle 1538; Yumury Mountains, Rugel 873; Santiago deCuba, Hamilton 209; Matanzas, Britton \& Wilson 457; Madruga, Britton \& Shafer 315, 736; Eggers 4639.

There are two Wright specimens of this in the Grisebach Herbarium, no. 162 of 1865 and no. 746 from eastern Cuba, 1859.

43. LITHACHNE Beauv. Agrost. 135. $t .24 . f .11 .1812$.

Blades ovate, 1 to $2 \mathrm{~cm}$. wide................................ pauciflora.

Blades oblong, less than $5 \mathrm{~mm}$. wide........................ L pineti.

1. Lithachne pauciflora (Sw.) Beauv.; Poir. Dict. Sci. Nat. 27: 60. 1823.

Olyra pauciflora Sw. Prod. 21. 1788.

Olyra axillaris Lam. Encycl. 4: 547. 1797.

Lithachne axillaris Beauv. Agrost. 166. t. 24.f. 11. 1812.

Wright 732; Santiago de las Vegas, Baker HC 4148, 5049, Hitchcock in 1906; San Antonio, Hitchcock in 1906; Cienfuegos, Pringle 54, Combs 319 in Gray Herbarium; Madruga, Curtiss 661; El Guama, Palmer \& Riley 105; Herradura, Baker HC 2941, Hitchcock in 1906; Habana, Leon 584. In the herbarium of the New York Botanical Garden: Santiago de Cuba, Hamilton 210; Eggers 5356.

There are three specimens of this in the Grisebach Herbarium, two from eastern Cuba, 1856-57 and 1859, both numbered 732, and one from western Cuba numbered "1133=732." One sheet of Wright 732 in the Gray Herbarium is from "Banks of river, Santa Cruz, San José, Apr. 8."

2. Lithachne pineti (Wright) Chase, Proc. Biol. Soc. Wash. 21: 182. 1908.

Olyra pineti Wright; Griseb. Mem. Amer. Acad. n. ser. 8: 532.1862.

Eastern Cuba in 1859, Wright 1536 in Grisebach Herbarium. There is a duplicate type in the Gray Herbarium.

44. MNIOCHLOA Chase, Proc. Biol. Soc: Wash. 21: 185. 1908.

Flowering culms much exceeding sterile ones; fruit glabrous......1. M. pulchella. Flowering and sterile culms about equal in height; fruit pubescent.2. M. strephioides.

1. Mniochloa pulchella (Griseb.) Chase, Proc. Biol. Soc. Wash. 21: 186. 1908.

Digitaria pulchella Griseb. Cat. PI. Cub. 231. 1866.

Strephium? pulchellum Wright, Anal. Acad. Cienc. Habana 8: 202. 1871; Sauv. Fl. Cub. 193.

Crece al borde de precipicios en el Yunque de Baracoa Wright 3448.

2. Mniochloa strephioides (Griseb.) Chase, Proc. Biol. Soc. Wash. 21: 186. 1908.

Olyra strephioides Griseb. Cat. Pl. Cub. 229. 1866.

Wright 3435; 'San Diego de los Baños, Caldwell \& Baker 7011.

The Grisebach specimen, which is the type, is from western Cuba, 1863, numbered "942=3435." 
45. PHARUS L. Syst. Nat. ed. 10. 2: 1269. 1759.

Culms creeping at base 3. P. parvifolius.

Culms not creeping at base.

Fruit pubescent only at the tip, slightly exceeding the glume...................................... P. latifolius.

Fruit pubescent all over, 2 to 3 times as long as the glume....1. P. glaber.

1. Pharus glaber H. B. K. Nov. Gen. \& Sp. 1: 196. 1816.

Dense woods, Valestina, September 27, Wright 733; Managuas, Baker HC 455; El Guama, Palmer \& Riley 123, 260; San Antonio, Hitchcock in 1906; Yumury Mountains, Rugel 871 in Gray Herbarium; Cienfuegos, Combs 363 in Gray Herbarium.

The Wright specimens in the Grisebach Herbarium are no. 268 of 1865, no. 733 from eastern Cuba, 1856-57, and no. 733 from eastern Cuba, 1859. The following are in the herbarium of the New York Botanical Garden: Santiago de Cuba, Taylor 40, 275, 284, 479; Matanzas, Britton \& Witson 66, 227; Madruga, Britton \& Shafer 789 ; Eggers 4708.

2. Pharus latifolius L. Syst. Nat. ed. 10. 2: 1269. 1759.

Santiago de Cuba, Taylor 217, Hamilton 211, both in Herb. N. Y. Bot. Gard.

3. Pharus parvifolius Nash, Bull. Torr. Club 35: 301. 1908.

Jaguey, Eggers 4939, Maxon 4155, in Herb. N. Y. Bot. Gard.

This species, which also occurs in Haiti, differs in having stems with creeping bases.

46. LUZIOLA Gmel. Syst. Nat. 1: $636.1791 . a$

\section{Luziola bahiensis (Steud.)}

Caryochloa bahiensis Steud. Syn. P1. Glum. 1: 5. 1854.

Luziola alabamensis Chapm. Fl. So. U. S. 584. 1860.

Luziola longivalvula Doell in Mart. Fl. Bras. 22: 17. 1871.

In rivulets, the panicles just above the surface of the water, pinales, Pinar del Rio, December, Wright 3813.

In the National Herbarium are: Duplicate type of $L$. alabamensis Chapm., collected by J. F. Beaumont, Brooklyn, Alabama, in 1859; duplicate type of Caryochloa bahiensis Steud., and also of Luziola longivalvula Doell (Bahia, Salzmann; Brazil, Prov. Minas Geraes, Henschen 1376, cited by Doell).

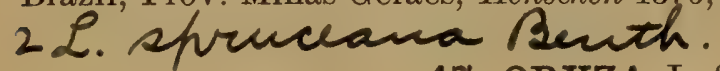

47. ORYZA L. Sp. Pl. 333. 1753.

1. Oryza sativa L. Sp. Pl. 333. 1753.

Wright 3838.

In the National Herbarium is another specimen numbered 191.

48. HOMALOCENCHRUS Mieg. Act. Helvet. Phys.-Math. 4: 307.1760.

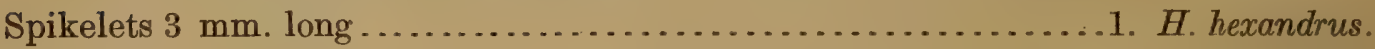

Spikelets $2 \mathrm{~mm}$. long.................................... Honandrus.

1. Homalocenchrus hexandrus (Sw.) Kuntze, Rev. Gen. P1. 2: 777. 1891.

Leersia hexandra $\mathrm{Sw}$. Prod. 21. 1788.

Wright 3434, 3837; Herradura, Hitchcock in 1906.

The Grisebach specimen is from eastern Cuba, 1860, numbered " $118=3434$." In Sauvalle's Flora Cubana this number is misprinted 3484. Wright's 3434 in the Gray Herbarium is from "San Mateo, in water 3 feet deep."

a Juss. Gen. P1. 33. 1789, without citation of species. 
Cuba, 1856-57 in Sauvalle Herbarium; Jata Hills at Guanabacoa, Hitchcock in 1906; Baker \& Hasselbring HC 7208, 7211; Madruga, Britton \& Shafer 658 in Herb. N. Y. Bot. Gard.

There are two Wright specimens of this in the Grisebach Herbarium, "Savannas of Guanacaro, July 28, in small tufts," no. 282 of 1865, and no. 736 from eastern Cuba, 1856-57.

This species is readily recognized by its stiff, rush-like culms and short sharppointed blades. On the Jata Hills it occurs on dry, grassy slopes.

\section{Aristida erecta sp. nov.}

Culms erect, rather stout, from a perennial root, about 1.5 meters high, glabrous; sheaths glabrous, longer than the internodes; blades glabrous beneath, scabrous on the nerves above, elongated, convolute, much attenuated at the tip, 3 to $5 \mathrm{~mm}$. wide, as much as 1 meter long; panicles $50 \mathrm{~cm}$. long, the numerous scabrous branches ascending below, spreading above, the lower as much as $20 \mathrm{~cm}$. long, all spikelet-bearing to the base; spikelets crowded, the pedicels erect, stout, 2 to $3 \mathrm{~mm}$. long, glumes glabrous, the first 12 to $15 \mathrm{~mm}$. long, scabrous on the keel, abruptly cuspidate or awntipped, 3-nerved, one of the lateral nerves somewhat indistinct, second glume 2 to 3 $\mathrm{mm}$. shorter, acuminate, 1-nérved, smooth on the keel, lemma 12 to $13 \mathrm{~mm}$. long, glabrous, the callus about $1 \mathrm{~mm}$. long, bearded, awns spreading, the central 2 to 3 $\mathrm{cm}$. long, the lateral somewhat shorter.

The type specimen was collected by Wright in Cuba in 1865, no. 41161, in the U.S. National Herbarium. This specimen is numbered in pencil 2432, which is an error for 3432 . The corresponding specimen in the Grisebach Herbarium was collected in western Cuba in 1863 and is numbered " $928=3432$." The only other specimen seen is: Herradura, Tracy 9076.

This species resembles $A$. palustris (Chapm.) Vasey, but differs in having taller culms, larger and more spreading panicles, and longer glumes and lemma. In $A$. palustris the panicle is narrow and strict, the glumes are about $10 \mathrm{~mm}$. long and nearly equal, and the lemma is only 7 to $8 \mathrm{~mm}$. long.

3. Aristida mohrii Nash, Bull. N. Y. Bot. Gard. 1: 436. 1900.

In roads Hanabana, January 16, Wright 737; Wright 3433 in part; Wright 742 in National Herbarium; Jata Hills at Guanabacoa, Hitchcock in 1906; La Caimanera, Eggers 5389.

The Grisebach specimen is from eastern Cuba in 1856-57, no. 737. Another Grisebach specimen, Wright " $931=3433$ " from western Cuba, 1863, is doubtfully referred here. It appears to be the same as the fragmentary specimen no. 742 , mentioned abovie.

4. Aristida refracta Griseb. Cat. Pl. Cub. 228. 1866.

Aristida gyrans Chapm. Bot. Gaz. 3: 18. 1878.

Dry savannas, Chirigote, October 26 , Wright 3431 ; dry savannas, Chirigote, October 31, Wright 3832; in dense bunches along rivulets in sandy soil, Pinar del Rio, October, Wright 3834 ; in small dense tufts, sandy pine woods, Coloma, Pinar del Rio, October, Wright 3833; Wright 3430, 3831; Jata Hills at Guanabacoa, Hitchcock in 1906; Herradura, Hitchcock in 1906; Isle of Pines, Palmer.\& Riley 995, Taylor 20.

In the Grisebach Herbarium are three Wright specimens of this: Western Cuba, 1863, no. "926=3431;" eastern Cuba, 1860, no. "122=3430;" western Cuba, 1863, no. "908=3430." $x=$ us $p$; alsu Leon 475

5. Aristida scabra (H. B. K.) Kunth, Rev. Gram. 62. 1829.

Streptachne scabra H. B. K. Nov. Gen. \& Sp. 1: 124. 1816.

Streptachne cubensis Rich.; Sagra, Hist. Cub. 11: 311. 1850.

Pebbly pinales in small bunches, Pinar del Rio, October, Wright 3835; Puentes Grandes, Leon 280; Triscornia, Hitchcock in 1906; Cojimar, Hitchcocí in 1906.

The type of Streptachne cubensis is at Paris. 
52. MUHLENBERGIA Schreb. Syst. Nat. ed. 13. 2: 87. 171. 1791

1. Muhlenbergia capillaris (Lam.) Trin. Gràm. Unifl. 191. 1824.

Stipa capillaris Lam. Tabl. Encycl. 1: 158. 1791

In dense tufts, Guinamar, October, Wright 3836.

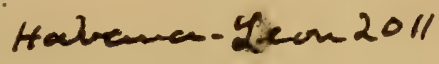

53. SPOROBOLUS R. Br. Prod. Fl. Nov. Holl. 169. 1810.

Plants producing long rhizomes; blades conspicuously distichous .5. S. virginicus.

Plants cespitose not producing rhizomes; blades not distichous.

Panicle dense and spike-like........................ S. S. indicus.

Panicle open.

Spikelets about $1.5 \mathrm{~mm}$. long; panicle pyramidal........ S. S. argutus.

Spikelets 2.5 to $4 \mathrm{~mm}$. long; panicle elongated-oblong.

Spikelets $2.5 \mathrm{~mm}$. long; basal sheaths not felty........ 4. S. purpurascens.

Spikelets 3.5 to $4 \mathrm{~mm}$. long; basal sheaths copiously felty-ciliate............................. S. cubensis.

1. Sporobolus argutus (Nees) Kunth, Enum. 1: 215. 1833.

Vilfa arguta Nees, Agrost. Bras. 295. 1829.

Wright 3828; Habana, Baker HC 1799, Leon 285; Batabano, Shafer 484, Hitcheock in 1906; Triscornia, Hitchcock in 1906. The following are in the herbarium of the New York Botanical Garden: Habana, Baker 1818; Guantanamō, Earle 86.

The type of Nees's species is at Munich. It is not the same as Vilfa domingensis Trin., to which it has sometimes been referred. The Grisebach specimen of this, no. 300 of 1865, consists of two plants with two labels, "Saline grounds, in tufts, Matanzas, July 17," and, "Sand banks by the seashore, Palma Sola, Aug. 8."

\section{Sporobolus cubensis sp. nov.}

Culms cespitose, glabrous; slender, erect, 40 to $60 \mathrm{~cm}$. high; leaves of innovations - numerous, the sheaths copiously felty-ciliate on the margins, with white, yellow, or brown hairs, which extend upward along the margins of the blade for a short distance; basal blades very long and narrow, flat, or involute, nearly as long as the culms, 1 to 2 $\mathrm{mm}$. wide, smooth except for the basal hairs, strongly striate-nerved, the two or three upper blades short, 2 or $3 \mathrm{~cm}$. long; panicle slender-pyramidal, glabrous throughout, 8 to $10 \mathrm{~cm}$. long, branches verticillate, lowermost 5 to 8 in a whorl, slender and stiffly spreading, 1.5 to $3 \mathrm{~cm}$. long; spikelets glabrous, tawny, 3.5 to $4 \mathrm{~mm}$. long, appressed, on pedicels 0.5 to $1 \mathrm{~mm}$. long; lower glumes rather broad, one-third to one-half the length of the spikelet, 1-nerved, the upper glume and lemma about equal, weakly 1-nerved; palea as long as or longer than the lemma; grain oval, flat, $2 \mathrm{~mm}$. long.

Type specimen, Isle of Pines, Curtiss 392, U. S. National Herbarium no. 522010. Other specimens are: Herradura, Hitchcock in 1906; Wright 3427 in Sauvalle Herbarium.

Wright's 3427 in the National Herbarium consists of this species, together with $S$. purpurascens. S. cubensis is distinguished from $S$. purpurascens by its larger spikelets, $3.5 \mathrm{~mm}$. long, the elongated blades, and the ferruginous-silky basal sheaths. Heller's 4590 from Porto Rico is $S$. cubensis. In the Grisebach Herbarium are three specimens of this from Wright: No. 3427 a of $1860-64$; no. " $922=3422$ " from western Cuba, 1863; and no. " $945=3422$ " from western Cuba, 1863. (No. 3422 as published in Grisebach's Catalogue, is Eragrostis sudans). It will be noted that nos. 3427 and 3427 a are the reverse of what they are in the Sauvalle Herbarium. Wright's 3427 in the Gray Herbarium is from "High pine woods, pinales, Mar. 1;" another sheet of this number is part $S$. cubensis and part $S$. purpurascens.

3. Sporobolus indicus (L.) R. Br. Prod. Fl. Nov. Holl. 170. 1810.

Agrostis indica L: Sp. PI. 63. 1753.

Sporobolus jacquemontii Kunth, Rev. Gram. 2: 427. 1831.

$a$ Gen. P1. 44. 1789, without citation of species. 
Savannas, San Cristobal, August, Wright 2829; Wright 3426; Cojimar, Baker HC 5197, 5334; Santiago de las Vegas, Baker HC 537, 5111, Hitchcock in 1906; Triscornia, Tracy 9081; Guanabacoa, Leon 186; Puentes Grandes, Leon 275, 282; Habana, Baker HC 1279; Madruga, Shafer 67; Matanzas, Britton \& Wilson 473; Batabano, Shafer 486; Herradura, Tracy 9064, 9066, Hitchcock in 1906; Consolacion del Sur, Palmer \& Riley 473; San Diego de lós Baños, Palmer \& Riley 627; Coloma, Palmer \& Riley 349; El Guama, Palmer \& Riley 404; Isle of Pines, Palmer \& Riley 1121, Taylor 48, Curtiss 323; Arroyo Apolo, Leon 586; Cienfuegos, Combs 261 and 263 in Gray Herbarium. The following are in the herbarium of the New York Botanical Garden: Santiago de Cuba, Taylor 91; Isle of Pines, Curtiss in 1904; Madruga, Britton \& Shafer 721; Eggers 5361.

The three Wright specimens in the Grisebach Herbarium are: Eastern Cuba, 1860, no. " $119=3426$;" no. 299 of 1865; and eastern Cuba, 1859, no. 1537. In Sauvalle's Flora Cubana the number appears as 3829 instead of 2829 . The specimen in the Gray Herbarium is numbered 3829.

4. Sporobolus purpurascens (Sw.) Hamilt. Prod. Fl. Ind. Occ. 5. 1825.

Agrostis purpurascens Sw. Prod. 25. 1788.

Vilfa grisebachiana Fourn. Mex. P1. 2: 98. 1886.

Sandy pine woods in large tufts, Pinar del Rio, October, Wright $3427 \mathrm{a}$.

The two Wright specimens in the Grisebach Herbarium are: no. " $907=3427$ " from western Cuba, 1863, and 'no. " $885=3427$ ", 1863. The type of Swartz's species is 'at Stockholm; the spikelets are $2.5 \mathrm{~mm}$.long. Fournier noticed the difference between the two species (S. cubensis and S. purpurascens) distributed by Wright under 3427 , but described as new the one already named. Wright 3427a in the Gray Herbarium is from "savannas, Chirigote, July 11."

5. Sporobolus virginicus (L.) Kunth, Rev. Gram. 1: 67. 1829.

Agrostis virginica L. Sp. Pl. 63. 1753.

Wright 291; Wright 2830 in National Herbarium; Habana, Baker HC 1810, Leon 284; Mariel, Palmer \& Riley 736; Isle of Pines, Palmer \& Riley 955, 1122; Matanzas, Britton \& Wilson 151 in Herb. N. Y. Bot. Gard.

The Grisebach specimen is no. 291 in 1865, "Seashore, Matanzas, July 8." .In Sauvalle's Flora Cubana this is numbered 3830 , which is probably correct, as the specimen in the Gray Herbarium is also numbered 3830.

54. CAPRIOLA Adans. Fam. Pl. 2: 31, 532. 1763.a

1. Capriola dactylon (L.) Kuntze, Rev. Gen. Pl. 2: 764. 1871.

Panicum dactylon L. Sp. P1. 58. 1753.

Cynodon dactylon Pers. Syn. 1: 85. 1805.

Wright 3814; Santiago de las Vegas, Baker HC 386, Hitchcock in 1906; Habana, Leon 290; Cienfuegos, Combs 540 in Gray Herbarium.

55. CHLORIS Sw. Prod. 25. 1788.

Spikelets awnless; spikes dark brown.....................6. C. petraea.

Spikelets awned; spikes green or yellow.

Spikelets distant, diverging; spikes delicate, scarcely 1-sided.2. C. cruciata.

Spikelets contiguous; spikes not delicate, conspicuously

1-sided.

$a$ There is some question as to the standing of Capriola as a genus, since it is based upon "Gramen dactylon offic." (Adans. Fam. 2: 31 and 532. 1763.) But since Linnæus cites under Panicum dactylon "Gramen dactylon, radice repente, S. officinarum Scheuch. Gram. 104" we may assume that Adanson wished to base his genus on this species, though he does not quote a definite author. 
Upper floret truncate-dilated.

Awns 1 to $2 \mathrm{~mm}$. long; lower lemma long-ciliate on the keel and lateral veins, but not at apex......... C. ciliata.

Awns, or some of them, $5 \mathrm{~mm}$. long or more; lower lemma ciliate on the upper part of marginal nerves, not on keel............................. . C. paraguaiensis.

Upper floret narrowed toward apex.

Lower lemma strongly ciliate at apex with tuft of hairs $2 \mathrm{~mm}$. long............................. C. elegans.

Lower lemma only pubescent at apex.

Lower lemma $3 \mathrm{~mm}$. long; blades short and flat, abruptly rounded at apex.................. . C. radiata.

Lower lemma $2 \mathrm{~mm}$. long; blades mostly involute-pointed .......................... C. eleusinoides.

1. Chloris ciliata Sw. Prod. 25. 1788.

Trinidad, May 17, Wright 743; Vento, Baker HC 1184, Curtiss 600; Guanabacba, Leon 185 in part; Santiago de las Vegas, Tracy 9115, Hitchcock in 1906; Triscornia 9085; Habana, Tracy 9106; Herradura, Hitchcock in 1906; Arroyo Apolo. Leon 574.

2. Chloris cruciata (L.) Sw. Prod. 25. 1788.

Agrostis cruciata L. Syst. Nat. ed. 10. 2: 873. 1759.

Chloris brevigluma Wright, Anal. Acad. Cienc. Habana 8: 200. 1871; Sauv. Fl. Cub. 191.

Bushy savannas, Hanabana, May 16, Wright 1549; Punta Brava, Baker HC 4067; Guanabacoa, Baker HC 2927, Curtiss 584, Hitchcock in 1906; Madruga, Britton \& Shafer 604 in Herb. N. Y. Bot. Gard.

There are three Wright specimens of this species in the Grisebach Herbarium: Nos. " $917=1548 "$ and " $932=1548$ " from western Cuba, 1863, and no. 1549 from eastern Cuba, 1859. The type of C. brevigluma is in the Gray Herbarium with printed label for 1860-64, no. 1548. In Sauvalle's Flora Cubana the type is misprinted "1848 p. p." Wright seems to have distinguished his species from C. eleusinoides mounted on the same sheet (Wright 1549), which he regarded as the true C. cruciata. Wright's type matches his no. 1549 in the National Herbarium.

3. Chloris elegans H. B. K. Nov. Gen. \& Sp. 1: 166. 1816.

Vento, Shafer 483, Baker HC 1183; Madruga, Britton \& Shafer 725; Mazarra, Baker HC 4023.

The type of this has not been examined, but the specimens eited above agree well with the plate accompanying the original description. ${ }^{a}$

4. Chloris eleusinoides Griseb. Fl. Brit. W. Ind. 539. 1864.

Chloris eleusinoides vestita Greenman in Combs, Trans. Acad. St. Louis 7: 477. 1897.

Sandy pine woods, La Griźa, January, Wright 3819; Wright 3818; Wright 1548; Baker HC 4067; La Magdalena, Baker Pl. Trop. Am. 4; Havana, Leon 287; Herradura, Hitchcock in 1906; Cienfuegos, Combs 631 in Gray Herbarium.

The Grisebach specimen is from eastern Cuba, 1859, no. 1548. Nos. 1548 and 1549, in the Engelmann Herbarium, both from eastern Cuba, 1860, are Chloris eleusinoides. No. 1549 in the Gray Herbarium is also this species (Monte Verde, eastern Cuba in 1859).

Combs's 631, from Cienfuegos, in the Gray Herbarium is the type of C.eleusinoides variety vestita. It differs from Grisebach's type in being somewhat more pubescent. 
5. Chloris paraguaiensis Steud. Syn. Pl. Glum. 1: 204. 1854.

Andropogon barbatum L. Mant. 2: 302. 1771, not L. 1759.

Chloris barbata Sw. Fl. Ind. Occ. 1: 200.1797 (based on Andropogon barbatum L. Mant.), not C. barbata Nash, Bull. Torr. Club 25: 443.1898 (based on Andropogon barbatum L. Syst.).

Habana, Baker HC 3388, Tracy 9113, Palmer \& Riley 1150; Triscornia, Tracy 9084, Hitchcock in 1906, Baker HC 1864; Matanzas, Britton 491; Regla, Shafer: Vedado, Baker HC 1441; Playa de Cojimar, Hitchcock in 1906; Santiago de Cuba, Millspaugh 1064; Mariel, Palmer \& Riley 725; Herradura, Hitchcock in 1906. In the herbarium of the New York Botanical Garden: Isle of Pines, Curtiss in 1904; Santiago de Cuba, Underwood \& Earle 101.

6. Chloris petraea Sw. Prod. 25. 1788.

Eustachys petraea (Sw.) Desv. Nuov. Bull. Soc. Philom. 2: 189. 1810.

Wright 293; Wright 3817 in National Herbarium; Cojimar, Baker HC 2867, Hitchcock in 1906; Habana, Liebmann 235; Isle of Pines, Palmer \& Riley 969. In the herbarium of the New York Botanical Garden: Matanzas, Britton \& Shafer 16; Isle of Pines, Curtiss in 1904.

The specimen in the Grisebach Herbarium is numbered 293, 1865. The number 3719 , listed in Sauvalle's Flora Cubana under this species, is probably an error. Doell changes the name of $C$. petraea $\mathrm{Sw}$. to $C$. swartziana a because of the different $C$. petraea Thunb.b

7. Chloris radiata (L.) Sw. Prod. 26. 1788.

Agrostis radiata L. Syst. Nat. ed. 10. 2: 873. 1759.

Eastern Cuba, 1856-57, Wright 742; Santiago de las Vegas, Tracy 9110, Hitchcock in 1906; Playa de Cojimar, Hitchcock in 1906; Triscornia, Hitchcock in 1906; Habana, Leon 558.

56. BOUTELOUA Lag. Var. Cienc. $2^{4}: 134.1805 . c$

Primary racemes few, distant on the main axis (5 to $15 \mathrm{~mm}$. apart);

blades 1 to $2 \mathrm{~mm}$. wide................................. B. americana.

Primary racemes numerous, secund, approximate ( 1 to $5 \mathrm{~mm}$. apart);

blades 3 to $5 \mathrm{~mm}$. wide................................. B. disticha.

1. Bouteloua americana (L.) Scribn. Proc. Acad. Phila. 1891: 306.1891.

Aristida americana L. Syst. Nat. ed. 10. 2: 879. 1759.

-Bouteloua litigiosa Lag. Gen. \& Sp. Nov. 5. 1816.

- Bouteloua humboldtiana Griseb. Mem. Amer. Acad. n. ser. 8: 532. 1862.

Bouteloua porphyrantha Wright, Anal. Acad. Cienc. Habana 8: 201. 1871; Sauv. Fl. Cub. 192.

Wright 165, 166, 3816; Wright 3815 and 734 in Gray Herbarium; Triscornia, Baker HC 1873, Tracy 9088, Hitchcock in 1906; Habana, Curtiss 546, Leon 293; Colima, Baker HC 1978; La Magdaléna, Baker HC 3621, Regla, Shafer 489; Guanabacoa, Leon 38; Marianao, Leon 231; Cojimar, Hitchcock in 1906.

The Grisebach specimens are Wright 161 of 1865 , "Bushy savannas, Hanabana, June $1, "$ and 739, from eastern Cuba, 1859. The specimens cited above agree with the Linnæan type, which is not Aristida dispera Trin. as stated by Munro.d

2. Bouteloua disticha (H. B. K.) Benth. Journ. Linn. Soc. 19: 105. 1882.

Polydon distichus H. B. K. Nov. Gen. \& Sp. 1: 175. 1816.

Madruga, Curtiss 537; Habana, Leon 299.

$a$ In Mart. Fl. Bras. $2^{3}: 68.1878 . \quad c$ Botelua in the original.

$b$ Prod. 20. 1794 a Proc. Linn. Soc. Bot. 6: 49. 1862.

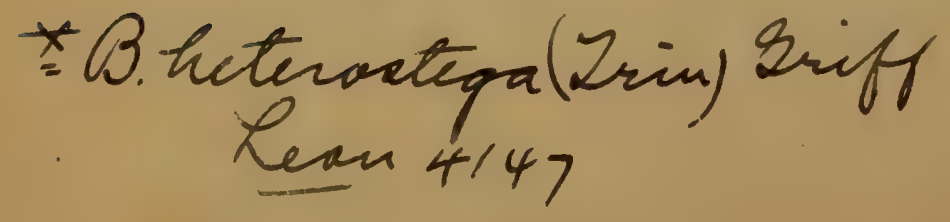


57. ELEUSINE Gaertn. Fruct. \& Sem. 1: 7. $p l .1 .1788$.

1. Eleusine indica (L.) Gaertn. Fruct. \& Sem. 1: 8. 1788.

Cynosurus indicus L. Sp. P1. 72. 1753.

Saline flats, Matanzas, July 4, Wright 744; Santiago de las Vegas, Baker HC 513, 1139, Hitchcock in 1906; Puentes Grandes, Leon 278; Habana, Leon 294; Guanajay, Palmer \& Riley 817; Santiago de Cuba, Millspaugh 1111; Cienfuegos, Combs 260 in Gray Herbarium; Isle of Pines, Curtiss in 1904 in Herb. N. Y. Bot. Gard.

The Grisebach specimen is no. 277 of 1865 . The Sauvalle specimen also bears the secondary number 277 .

58. DACTYLOCTENIUM Willd. Enum. 1029. 1809.

1. Dactyloctenium aegyptium (L.) Richt. Pl. Eur. 1: 68. 1870.

Cynosurus aegyptius L. Sp. P1. 72. 1753.

Pine woods, Nueva Filipina, Wright 3821 (misprinted 3831 in Sauvalle's Flora Cubana); Habana, Leon 289, 554, Baker HC 1795, Curtiss 636; Puentes Grandes, Leon 273; Triscornia, Hitchcock in 1906; Cojimar, Hitchcock in 1906; Batabano, Baker HC 3919; Cienfuegos, Combs 513 in Gray Herbarium.

59. LEPTOChlo A Beauv. Agrost. 71. pl. 15.f. 1. 1812.

Spikelets 2 to 4 -flowered, imbricated, on one side of the panicle branches.

Upper glume as long as lower lemma; sheaths papillose-hispid...2. L. mucronata.

Upper glume shorter than lower lemma; sheaths smooth........ 4. L. virgata.

Spikelets several-flowered; inflorescence not conspicuously 1-sided.

Inflorescence a single spike............................... L. spicata.

Inflorescence of several spike-like racemes................. L. fascicularis.

1. Leptochloa fascicularis (Lam.) Gray, Man. 588. 1848.

Festuca fascicularis Lam. Tabl. Encycl. 1: 189. 1791.

In tufts, ditches, Matanzas, July 6, Wright 303; Wright 3822; Wright 3812 in National

Herbarium; Batabano, Baker HC 2762, Hitchcock in 1906. In the herbarium of the New

York Botanical Garden: Matanzas, Britton \& Wilson 176; Batabano, Shafer 488.

The Grisebach specimen collected in 1865 is numbered 303.

2. Leptochloa mucronata (Michx.) Kunth, Rev. Gram. 1: 91. 1829.

Eleusine mucronata Michx. Fl. Bor. Amer. 1: 65. 1803.

In fields, Punta de Palma, September, Wright 740; Habana, Britton \& Wilson 509, Hitchcock in 1906; Isle of Pines, Curtiss 508; Guanabacoa, Leon 580.

In the National Herbarium are two Wright specimens of this, numbered 740 and 741. The latter number is probably an error, the label having been interchanged with that of a specimen of $L$. fascicularis. In the Gray Herbarium there are two sheets numbered 741, of which one is $L$. filiformis from "Cultivated ground, Valestina, Nov. $12, " 1865$, the other $L$. virgata.

The type of Festuca filiformis Lam.a "ex Amer. merid. Comm. D. Richard" upon which Leptochloa filiformis Beauv. is presumably based, has not been examined, and the description is insufficient for identification. This name may be found to apply to this species.

3. Leptochloa spicata (Nees) Scribn. Proc. Acad. Phila. 1891: 304. 1891.

Bromus spicatus Nees, Agrost. Bras. 471. 1829.

Triscuspis simplex Griseb. Mem. Amer. Acad. n. ser. 8: 532. 1862.

Wright 1551.

There are two Wright specimens in the Grisebach Herbarium, both from eastern Cuba, no. 114 of 1860 and no. 1551 of 1859 . Wright's 1551 is represented in the Gray

a Tabl. Encycl. 1: 191. 1791.

61170 -VOL 12 , PT $6-09-5$ 
Herbarium by two specimens, one of 1860-64, labeled "Savannas, Hoto del Medio, Aug. 25," the other, Monte Verde, 1859, labeled "On rocks exposed to the sun, covered with a thin stratum of earth, on the brink of the Farallones, Oct. 11."

4. Leptochloa virgata (L.) Beauv. Agrost. 166. 1812.

Cynosurus virgatus L. Syst. Nat. ed. 10. 2: 876. 1759.

Leptochloa perennis Hack. Inf. Anal. Est. Agr. Cuba 1: 411. 1906.

Wright 283, 741, 3436; Habana, Tracy 9108, Curtiss 607; La Magdalena, Baker HC 3635; Matanzas, Britton 543; Santiago de las Vegas, Hitchcock in 1906; Herradura, Baker HC 765, 2786, Tracy 9061, Hitchcock in 1906; Cayamas, Baker HC 4617; Cienfuegos, Pringle 62, Combs 256 in Gray Herbarium; San Diego de los Baños, Palmer \& Riley 543; Santiago de Cuba, Pollard, Palmer \& Palmer 273; Marianao, Leon 560; Yumury Mountains, Rugel 193 in Gray Herbarium. In the herbarium of the New York Botanical Garden are: Santiago de Cuba, Palmer 273; Baracoa, Underwood \& Earle 1397; Madruga, Britton \& Shafer 746.

Wright's 741 in the Sauvalle Herbarium has also the secondary number 278. In the Grisebach Herbarium are three specimens of this: "In roads, probably introduced, La Ferruina, June 24 ," no. 278 of 1865 ; no. 3436 of $1860-64$; no. " $117=7.40$ " from eastern Cuba, 1860. One of the Wright specimens bearing the number 741 in the Gray Herbarium (eastern Cuba, 1856-57) is L. virgata: the other is L. mucronata. Wright's 3436 in the Gray Herbarium is from Mayarí Abajo, Aug: 2. Another specimen in the Gray Herbarium without number is from "Savannas, Retiro, Oct. 11."

60. OPIZIA Presl, Rel. Haenk. 1: 293. t. 41. f. 1. 1830.

1. Opizia stolonifera Presl, Rel. Haenk. 1: 293. 1830.

Cojimar, Baker HC 2898, 5076, Hitchcock in 1906; Pinar del Rio, Shafer 482; Habana, Curtiss 571, Leon 274, 288.

61. PAPPOPHORUM Schreb.; Vahl, Symb. Bot. 3: 10. 1794.a

1. Pappophorum laguroides Schrad. in Schult. Mant. 2: 342. 1824.
Triscornia, Hitchcock in 1906. - E on $2010=P_{1}$

62. GYNERIUM H. B. K. P1. Aequin. 2: 112. t. 115. 1809.

1. Gynerium sagittatum (Aubl.) Beauv. Agrost. 138. 1812.

Saccharum sagittatum Aubl. Pl. Guian. 1: 50. 1775.

Gynerium saccharoides H. B. K. P1. Aequin. 2: 112. 1809.

Retiro, Wright 224; Wright 3477; Santiago de las Vegas, Baker HC 1297, 5017, Wilson 237; San Diego de los Baños, Palmer \& Riley 616. In the herbarium of the New York Botanical Garden are the following: Matanzas, Britton \& Shafer 265, Britton \& Wilson 205; Santiago de Cuba, Taylor 145; Calvario, Leon 569.

In the Grisebach Herbarium are Wright 3477, 1860-64, and 1560 of 1859 . Wright's 1560 in the Gray Herbarium is from Monte Verde; no. 3477 is labeled "10-15 ft. panicle 4-6 ft. On stony ledges in the river Tacotaco, Sept. 13."

63. ERAGROSTIS Host, Icon. Gram. Austr. 4: 14. pl. 14. f. 11. 1809.b

Flowers diøcious; creeping annuals .................... E. hypnoides.

Flowers perfect, stems not creeping.

Palea prominently ciliate; annuals.

Panicle contracted, spike-like................... E. citiaris.

Panicle open............................... 8. E. plumosa.

$a$ Schreb. Gen. 2: 787. 1791, without citation of species.

$b$ Until the genus Eragrostis is monographed the Cuban species must remain somewhat uncertain.

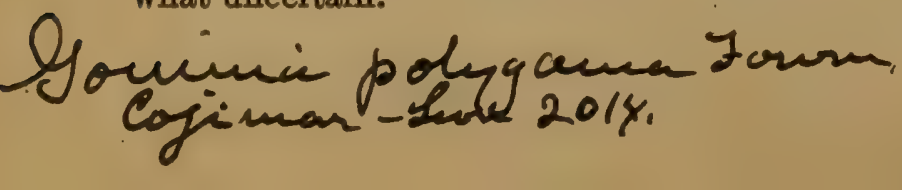


Palea not prominently ciliate.

Annual; blades flat; panicle open but not very diffuse ..9. E. tephrosanthes. Perennial.

Plants low, 10 to $20 \mathrm{~cm}$. high; blades involute, panicle not diffuse.

Spikelets 3 to 5 -flowered; pedicels glutinous; palea somewhat ciliate ...................6. E. glutinosa

Spikelets many-flowered; pedicels not glutinous;

palea only minutely ciliate................ E. cubensis.

Plants tall; blades flat; panicles very diffuse.

Spikelets less than $2 \mathrm{~mm}$. long, 1 or 2 -flowered..1. E. airoides.

Spikelets 5 to $10 \mathrm{~mm}$. long, several-flowered.

Spikelets lanceolate; pedicels shorter than spikelets; panicle branches lax; culms 1

meter or more tall ...................5. E. excelsa.

Spikelets linear; pedicels mostly longer than spikelets; panicle branches stiffly spread-

ing; culms rarely over $60 \mathrm{~cm}$. tall........ E. elliottii.

1. Eragrostis airoides Nees, Agrost. Bras. 509. 1829. $=S_{-2} \sigma_{2}$ In savannas, Chirigote, November 2, Wright 3827.

2. Eragrostis ciliaris (L.) Link, Hort. Berol. 1: 192. 1827.

Poa ciliaris L. Syst. Nat. ed. 10. 2: 875. 1759.

Wright 155; Wright 1550; Cojimar, Hitchcock in 1906; Batabano, Baker HC 3912; Guines, Baker HC 3561; Robles, Shafer 40; Guanabacoa, Leon 196; Puentes Grandes, Leon 281; Herradura, Baker HC 2778; Matanzas, Palmer \& Riley 13; El Guama, Palmer \& Riley 185; Santiago de Cuba, Millspaugh 1062; Cienfuegos, Combs 480 in Gray Herbarium. In the herbarium of the New York Botanical Garden are the following: Isle of Pines, Curtiss in 1904; Matanzas, Britton \& Shafer 555; Santiago de Cuba, Underwood \& Earle 172.

The Wright specimen in the National Herbarium bears the secondary number 305. In the Grisebach Herbarium are two Wright specimens of this, no. 305 of 1865 and no. 1550 from eastern Cuba, 1859. In the Gray Herbarium are two specimens of Wright 1550, one of 1860-64, the other from Josephina, near Monte Verde, 1859.

\section{Eragrostis cubensis sp. nov.}

Culms cespitose from a perennial base, numerous, slender and wiry, smooth, erect or spreading, 10 to $20 \mathrm{~cm}$. long, or occasionally decumbent and as much as $30 \mathrm{~cm}$. long; sheaths smooth, striate; blades filiform-convolute, glabrous, or very sparsely pilose, the base and mouth of sheath pilose, 2 to $3 \mathrm{~cm}$. long, or those on the innovations as much as $10 \mathrm{~cm}$. long; panicles nearly simple, 2 to $4 \mathrm{~cm}$. long, the branches 1 to $2 \mathrm{~mm}$. long, bearing a single spikelet, or the lowermost as much as $1 \mathrm{~cm}$. long, bearing 2 to 4 spikelets; spikelets linear, 5 to $15 \mathrm{~mm}$. long, $1 \mathrm{~mm}$. wide, as much as 40 flowered; glumes smooth, nearly equal, about $1 \mathrm{~mm}$. long; lemma acute, 3-nerved, glabrous, keel smooth; palea minutely ciliate.

Isle of Pines, Curtiss 420 (type U. S. National Herbarium no. 522037); Wright 3424, 3825; Vedado, Baker HC 3456; Madruga, Shafer 68; La Magdalena, Baker Pl. Trop. Amer. 3; Herradura, Tracy 9097, Baker HC 2938, 4876, 4877, Hitchcock in 1906; Sagua, Britton \& Wilson 382 in Herb. N. Y. Bot. Gard.

This has been confused with E. bahiensis Steud.; which is a larger plant, $60 \mathrm{~cm}$. or more tall. E. berteroiana (Schult.) Kunth, of Santo Domingo, has smaller spikelets with lemmas scabrous on the keel, as shown by a specimen from Kunth in Trinius's herbarium. The Grisebach specimen from Wright is numbered " $938=3424$," and is from western Cuba, 1863, "bushy swamps, Hanabana, May 16." Another

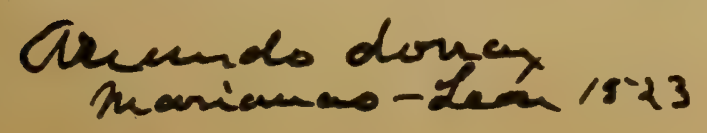


is from western Cuba, 1863, and is numbered 903. Wright's 3424 in the Gray Herbarium is from "savannas, Chirigote, July 13."

This is described and figured by Sloane, $a$ and is cited as a synonym by Swartz under Poa glutinosa $b$ and by Grisebach;c but Poa glutinosa Sw. is Eragrostis sudans Griseb., while Wullschlaegel's specimen from Jamaica, cited by Grisebach under Eragrostis glutinosa, is E. elliottii S. Wats.

4. Eragrostis elliottii S. Wats. Proc. Amer. Acad. 25: 140. 1890.

Poa nitida Ell. Bot. S. C. \& Ga. 1: 162. 1816, not Poa nitida Lam. 1791, nor Eragrostis nitida Link, 1827.

Eragrostis macropoda Pilger in Urban, Symb. Antill. 4: 106. 1903.

Savannas, Retiro, June, Wright 3423; without data, Wright; Cojimar, Baker HC 5332; Pinar del Rio, Baker \& Abarca HC 3735, Palmer \& Riley 441; Herradura, Tracy 9096, Hitchcock in 1906; Isle of Pines, Taylor 25. In the herbarium of the New York Botanical Garden are: Sagua, Britton \& Wilson 320; Isle of Pinés, Curtiss in $190^{\circ}$.

The Grisebach specimens are nos. 155, 155a, 155b, all of 1865 . Wright's 3423 in the Gray Herbarium is from "lagunas, Vueltabajo, July 24."

Pilger $d$ states that $E$. macropoda differs from $E$. nitida (Ell.) Chapm. in having long-peduncled spikelets. However, the type of Poa nitida Ell. has long-peduncled spikelets and is well matched by Wright 3423 .

5. Eragrostis excelsa Griseb. Cat. P1. Cub. 227. 1866.

Wright 3425.

The Grisebach specimen is no. 3425, 1860-64. Wright's 3425 in the Gray Herbarium is from "sand beaches by the seaside, Toscano, Oct. 30."

6. Eragrostis glutinosa (Sw.) Trin. Mem. Acad. Petersb. VI. 1: 397. 1831.

Poa glutinosa Sw. Prod. 26. 1788.

Eragrostis sudans Griseb. Cat. Pl. Cub. 227: 1866.

Wright 3422.

The Grisebach specimen is from eastern Cuba, 1860, numbered " $112=3422$." The Sloane $e$ figure cited by Swartz is Eragrostis cubensis Hitchc.

The type of Swartz's species in the Stockholm Herbarium is from Jamaica. In the Trinius Herbarium is a duplicate from Swartz, which is the basis of Eragrostis glutinosa Trin.

7. Eragrostis hypnoides (Lam.) B. S. P. Prel. Cat. N. Y. 69. 1888.

Poa hypnoides Lam. Tabl. Encycl. 1: 185. 1791.

Poa reptans Michx. Fl. Bor. Amer. 1: 69. 1803.

Eragrostis reptans Nees, Agrost. Bras. 514. 1829.

Around lagunas, Hanabana, May 20, Wright 156; Wright 3826; Laguna de Castellano, Baker HC 1356; Isle of Pines; Curtiss 391. The following are in the herbarium of the New York Botanical Garden: Habana, Baker 4328; Santiago de Cuba, Hamilton 214; Baracoa, Underwood \& Earle 1387.

The Grisebach specimen from Wright is no. 156. of 1865 .

$a$ Hist. Jam. 1: $p l . ~ \% 1 . f .2 .1707$.

$b$ Sw. Prod. 26. 1788.

c Fl. Brit. W. Ind. 532. 1864. $d$ Loc. cit.

$e$ Hist. Jam. 1: pl. 71.f. 2., 1707. 
8. Eragrostis plumosa (Retz.) Link, Hort. Berol. 1: 192. 1827.a

Poa plumosa Retz. Obs. 4: 20. 1786.

Santiago de las Vegas, Baker HC 1030; Habana, Hitchcock in 1906; Puentes Grandes, Leon 277; Santiago de Cuba, Palmer 374, Underwood \& Earle 173 in Herb. N. Y. Bot. Gard.

9. Eragrostis tephrosanthes Schult. Mant. 2: 316. 1824.

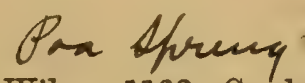

Wright 745; Santiago de las Vegas, Baker HC 3666; Vento, Witson 1182; Carduas, Britton \& Wilson 156a; Guanabacoa, Leon 205; Puentes Grandes, Leon 276; Habana, Leon 295, Hitchcock in 1906; Cojimar, Hitchcock in 1906; Herradura; Tracy 9057 , Hitchcock in 1906; Cienfuegos, Combs 266 in Gray Herbarium; Matanzas, Britton \& Shafer 557 in Herb. N. Y. Bot. Gard.

The Grisebach specimen is from Wright, 1860-64, without number. 'In the Gray Herbarium is a Wright specimen without number, with an 1860-64 label, and two specimens numbered 745 from eastern Cuba, one collected in 1856-57, the other in 1859 .

This species is similar to E. pilosa (L.) Beauv., but the spikelets are larger and broader.

64. UNIOLA L. Sp. PI. 71. 1753.

Spikelets $15 \mathrm{~mm}$. or more long, 7 to $10 \mathrm{~mm}$. wide ............. U. paniculata. Spikelets 2 to $3 \mathrm{~mm}$. long, 1 to $2 \mathrm{~mm}$. wide ................... U. virgata.

1. Uniola paniculata L. Sp. Pl. 71. 1753.

Wright 2823 [error for 3823].

The Grisebach specimen is labeled "Sandy sea-beach, Cananova, July 15," no. 280,1865 . In Sauvalle's Flora Cubana this is numbered 3823, which is apparently correct. The specimen in the Gray Herbarium is numbered 3823.

2. Uniola virgata (Poir.) Griseb. Fl. Brit. W. Ind. 531. 1864.

Poa virgata Poir. in Lam. Encycl. 5: 78. 1804.

Punta Brava, Rugel 870 in Grisebach Herbarium; also in the Gray Herbarium and that of the Ney York Botanical Garden.

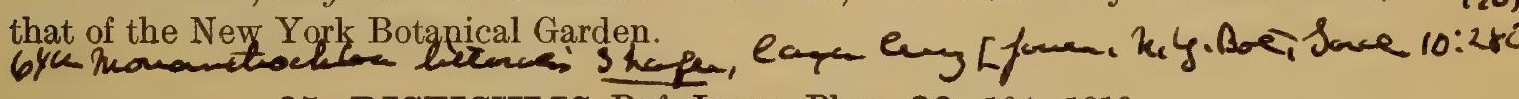

65. DISTICHLIS Raf. Journ. Phys. 89: 104. 1819.

1. Distichlis spicata (L.) Greene, Bull. Calif. Acad. Sci. 2: 415. 1887.

Uniola spicata L. Sp. Pl. 71. 1753.

Vedado, Baker HC 3455; Batabano, Shafer 117, Hitchcock in 1906.

66. ARTHROSTYLIDIUM Rupr. Mem. Acad. Petersb. VI. 5: 117. 1839.

Blades capillary $\ldots \ldots \ldots \ldots \ldots \ldots \ldots \ldots \ldots \ldots \ldots \ldots \ldots \ldots \ldots \ldots \ldots \ldots \ldots \ldots$. capillifolium.

Blades flat.

Blades less than $5 \mathrm{~cm}$. long.

Sheaths puberulent, bristles at summit inconspicuous...6. A. sarmentosum.

Sheaths glabrous, bristles at summit elongated.

Blades about $5 \mathrm{~mm}$. wide; spikelets reflexed.......4. A. distichum.

Blades about $2 \mathrm{~mm}$. wide; spikelets appressed......5. A. fimbriatum.

Blades $10 \mathrm{~cm}$. or more long.

Blades puberulent beneath, often reflexed.............7. A. urbanii.

Blades glabrous beneath, erect.

Blades 5 to $10 \mathrm{~mm}$. wide............................... cubense.

Blades about $2 \mathrm{~mm}$. wide, elongated............... A. angustifolium.

$a$ Trimen (Fl. Ceylon 5: 291. 1900) considers this different from E. tenella (L.) Roem. \& Schult. (Poa tenella L., Poa amabilis L.) and includes it as E. tenella plumosa (Retz.) Stapf; Fl. Brit. Ind. 7: 315. 1896.

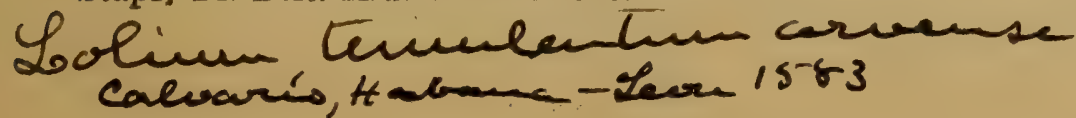


1. Arthrostylidium angustifolium Nash, Torreya 3: 172. 1903.

Baracoa, Underwood \& Earle 941 in Herb. N. Y. Bot. Gard.

2. Arthrostylidium capillifolium Griseb. Mem. Amer. Acad. n. sér. 8: 531. 1862. Without data, Wright: Madruga, Shafer 11; Santiago de Cuba, Taylor 218, Hamilton 212 , both in Herb N: Y. Bot. Gard.

The Wright specimen in the Grisebach Herbarium is no. 738 from eastern Cuba in 1856-57. Since the above specimen is the only Arthrostylidium in the Sauvalle Herbarium without number, it is probably the one listed under no. 2744 in Sauvalle's Flora Cubana, "Arthrostylidium sp.? (sine numero)."

In the Gray Herbarium are two specimens of Wright 738, both from eastern Cuba, one with flowers, collected in 1856-57, the other sterile, "In denșe woods, ascending on trees and bushes, 10-20 ft., Monte Verde, Aug. 22, 1859."

3. Arthrostylidium cubense Rupr. Mem. Acad. Petersb. VI. 5: 118. 1839.

"Pendant on cliffs, pinales, Nov.," "Banks of river San Sebastian, Pinar del Rio, Dec.," Wright 3811; without locality, Wright 3809.

The two Grisebach specimens are labeled "Subscandent, $10 \mathrm{ft}$., savannas of Guanacaro, near rivulets, Aug. 3," no. 307, 1865, and "Savannas of Guanacaro, July 31," no. 288. The Wright specimens agree with the type in the Trinius Herbarium.

4. Arthrostylidium distichum Pilger in Urban, Symb. Antill. 2: 342.1901.

"In dense woods, Oct. 19," "Damp woods, Rangel, Nov. 14," Wright 3808.

5. Arthrostylidium fimbriatum Griseb. Mem. Amer. Acad. n. ser. 8: 531. 1862.

Eastern Cuba in 1859, Wright 1554 in Grisebach Herbarium. This number in the Gray Herbarium is labeled, "In dense woods, 1-3 ft. high, Dec. 23," from Monte Verde, 1859. A sterile specimen in the herbarium of the New York Botanical Garden from Santiago de Cuba, Taylor 415, appears to be this species.

6. Arthrostylidium sarmentosum Pilger in Urban, Symb. Antill. 4: 108. 1903. Santiago de Cuba, Hamilton 213 in Herb. N. Y. Bot. Gard.

7. Arthrostylidium urbanii Pilger in Urban, Symb. Antill. 2: 339. 1901.

Wright 3810 .

In the Gray Herbarium there are two sterile specimens of what appear to be this species, numbered 41 and 288.

Gramen sp., Wright 3894. This number is represented by an unidentifiable fragmentary specimen from which the spikelets have fallen. It is listed in Sauvalle's Flora Cubana as "Muhlenbergia spicata Munn."

\section{GRASSES OF GRISEBACH'S CATALOGUE. ${ }^{a}$}

1. Arthrostylidium fimbriatum Gr. Wr. 1554. See p. 246.

2. Arthrostylidium cubense Rupr. Wr. a. 1865 (307).b See p. 246.

3. Arthrostylidium capillifolium Gr. Wr. 738. See p. 246.

4. Arundo saccharoides Gr. Wr. 1560, 3477. See Gynerium sagittatum, p. 242.

5. Uniola virgata Gr. Rug. 870. See p. 245.

6. Uniola paniculata L. Wr. a. 1865 (280). See p. 245.

7. Eragrostis excelsa Gr. Wr. 3425. See p. 244.

8. Eragrostis prolifera Steud. Wr. a. 1865 (155a). See E. elliottii, p. 244.

9. Eragrostis pilifera Benth. Wr. a. 1865 (156b). See E. elliottii, p. 244.

a Catalogus Plantarum Cubensium, 1866.

$b$ The numbers in parentheses refer to the secondary numbers on the labels in Grisebach's herbarium. The other numbers and the names are as given by Grisebach. The " $a$ " stands for anno. 
10. Eragrostis glutinosa Tr. Wr. 3423. See E. elliottii, p. 244.

11. Eragrostis pilosa P. B. Wr. 745. See E. tephrosanthes, p. 245.

12. Eragrostis bahiensis Schrad. Wr. 3424. See E. cubensis, p. 243.

13. Eragrostis reptans Ns. Wr. a. 1865 (156). See E. hypnoides, p. 244.

14. Eragrostis sudans Gr. Wr. 3422. See E. glutinosa, p. 244.

15. Eragrostis ciliaris Lk. Wr. 1550. See p. 243.

16. "Festuca laxiflora Rich." (Rich.) E. [No specimen found.]

17. Sporobolus virginicus Kth. Wr. a. 1865 (291). See p. 238.

18. Sporobolus domingensis Kth. Wr. a. 1865 (300). See Sporobolus argutus, p. 237.

19. Sporobolus purpurascens Ham. Wr. 3427. See p. 238, and S. cubensis, p. 237.

20. Sporobolus indicus R. Br. Wr. 1537. See p. 237.

21. Sporobolus jacquemontii Kth. Wr. 3426. See Sporobolus indicus, p. 237.

22. Reynaudia filiformis Kth. Wr. 3428. See p. 235.

23. Aristida stricta Mich. Wr. 736. See Aristida curtifolia, p. 235. Wr. 737. See A. mohrii, p. 236. Wr. 3430. See A. refracta, p. 236.

24. Aristida refracta Gr. Wr. 3431. See p. 236.

25. Aristida purpurascens Poir. Wr. 3432. See Aristida erecta, p. 236.

26. Aristida interrupta Cav. Wr. 3433. See Aristida mohrii, p. 236.

27. "Streptachne cubensis Rich." See Aristida scabra, p. 236.

28. Milium lanatum R. S. Wr. 3429. See Leptocoryphium lanatum, p. 207.

29. Leersia hexandra Sw. Wr. 3434. See Homalocenchrus hexandrus, p. 234.

30. Leersia monandra Sw. Wr. 731. See Homalocenchrus hexandrus, p. 234.

31. Achlaena piptostachya Gr. Wr. 3487. See p. 235.

32. Olyra latifolia L. Rug. 873; Wr. a. 1865 (162). See p. 233. Variety arundinacea Tr. Wr. 746. See Olyra latifolia, p. 233.

33. Olyra pauciflora Sw. Wr. 732. See Lithachne pauciflora, p. 233.

34. Olyra pineti Wr. Wr. 1536. See Lithachne pineti, p. 233.

35. Olyra strephioides Gr. Wr. 3435. See Mniochloa strephioides, p. 233.

36. Pharus latifolius L. Wr. 733. See Pharus glaber, p. 234.

37. Pharus glaber Kth. Wr. 733b. See p. 234.

38. Bouteloua humboldtiana Gr. Wr. 734, 739. See Bouteloua americana, p. 240.

39. Leptochloa mucronata Kth. Wr.740. See p.241. Wr.3436. See L. virgata, p. 242.

40. Leptochloa virgata P. B. Wr. 741. See p. 242.

41. Leptochloa fascicularis As. Gr. Wr. a. 1865 (303). See p. 241.

42. Tricuspis simplex Gr. Wr. 1551. See Leptochloa spicata, p. 241.

43. Chloris cruciata Sw. Wr. 1548, 1549. See p. 239.

44. Chloris eleusinoides Gr. See p. 239.

45. Chloris radiata $\mathrm{Sw}$. See p. 240.

46. Chloris ciliata Sw. Wr. 743. See p. 239.

47. Chloris petraea Thunb. Wr. a. 1865 (293). See p. 240.

48. Dactyloctenium "aegyptiacum W." See D. aegyptium, p. 241.

49. Eleusine indica G. Wr. 744. See p. 241.

50. Cynodon dactylon Pers. See Capriola dactylon, p. 238.

51. Reimaria acuta Fl. Wr. 3437. See Reimarochloa brasiliensis, p. 198.

52. Paspalum compressum Ns. Wr.a. 1865 (168). See Axonopus compressus, p. 207.

53. Paspalum platyphyllum Gr. Wr. 3441, Wr. a. 1865 (174). See Brachiaria plantaginea, p. 212.

54. Paspalum conjugatum Berg. Wr. 767. See p. 201.

55. Paspalum lindenianum Rich. Wr. 3445. See P. rupestre, p. 206.

56. Paspalum nanum Wr. Wr. a. 1865 (176). See p. 204.

57. Paspalum distichum $L$. variety vaginatum Sw. Wr. 1546. See P. distichum, p. 202, and P. vaginatum, p. 206.

58. Paspalum notatum Fl. Wr. 3438. See P. minus, p. 203.

59. Paspalum filiforme Sw. Wr. 769. See p. 202. 
60. Paspalum alterniflorum Rich. Rug. 894, Wr. a. 1865 (167). See p. 200.

61. Paspalum pulchellum Kth. Wr. 3439. See p. 205.

62. Paspalum dissectum L. Wr. 3440. See p. 202.

63. Paspalum setaceum Mich. Wr. 3442. See P. rigidifolium, p. 205.

64. Paspalum caespitosum Fl. Wr. 3443. See p. 201, and P. arenarium, p. 201. Wr. 3444. See p. 201, P. clavuliferum, p. 201, and P. rupestre, p. 206.

65. Paspalum glabrum Poir. Wr. a. 1865 (298). See p. 202.

66. Paspalum plicatulum Mich. Wr. 768. See p. 205.

67. Paspalum virgatum L. Wr. 3446. See p. 206.

Variety stramineum Gr. Wr. a. 1865 (302). See P. virgatum, p. 206.

68. Paspalum paniculatum L. Wr. 766. See p. 204.

69. Paspalum densum Poir. Wr. 3447. See p. 202.

70. Digitaria filiformis Muhlenb. Wr. 1544. See Syntherisma filiformis, p. 209, and S. leucocoma, p. 209.

71. Digitaria pulchella Gr. Wr. 3448. See Mniochloa pulchella, p. 233.

72. Digitaria marginata Lk. Wr. 765. See Axonopus compressus, p. 207.

Variety eriogona Lk. Wr. a. $1865(178,294)$. See Syntherisma sanguinalis, p. 209.

73. Digitaria setigera Rth. Wr. 764. See Syntherisma digitata, p. 209.

74. Eriochloa punctata Ham. Wr. 1542. See p. 208.

75. Stenotaphrum americanum Schrk. Wr. 3490. See Stenotaphrum secundum, p. 232.

76. Orthopogon "'hirtellus R. Br." See Oplismenus hirtellus, p. 229.

77. Orthopogon loliaceus Spreng. Wr. 751. See Oplismenus hirtellus, p. 229.

78. Orthopogon setarius Spreng. Wr. 1543. See Oplismenus hirtellus, p. 229.

79. Panicum lolium Ns. Wr. 3449. See Mesosetum rottboellioides, p. 211.

80. Panicum paspaloides Pers. Wr. 761. See Panicum geminatum, p. 222.

81. Panicum colonum L. Wr. 752. See Echinochloa colona, p. 213.

82. Panicum crusgalli L. Rug. 889. See Echinochloa crusgalli, p. 213.

83. Panicum prostratum Lam. Rug. 195; Wr. 762. See P. reptans, p. 225.

84. Panicum grossarium L. Wr. a. 1865 (304). See P. adspersum, p. 217.

85. Panicum distantiflorum Rich. Wr. 3452. See p. 220.

86. Panicum fuscum Sw. Wr. 754. See P. fasciculatum, p. 221.

87. Panicum molle Sw. Wr. 1545. See P. numidianum, p. 224.

88. Panicum oryzoides Sw. Wr. 3466. See P. zizanioides, p. 228.

89. Panicum stenodes Gr. Wr. a. 1865 (192). See p. 227.

90. Panicum neuranthum Gr. Wr. 3453. See p. 224. Wr. a. 1865. See P. chrysopsidifolium, p. 218 , and $\mathrm{P}$. fusiforme, p. 222 . $\beta$ ramosum. Wr. 3454. See P. chrysopsidifolium, p. 218, and P. fusiforme, p. 222.

91. Panicum proliferum Lam. variety pilosum. Wr. a. 1865 (186). See P. chloroticum, p. 218. Variety strictum. Wr. 3456. See P. chloroticum, p. 218.

92. Panicum diffusum Sw. Wr. 1540. See p. 220.

93. Panicum durum Gr. Wr. 1539. See Alloteropsis dura, p. 211.

94. Panicum laxum Sw. Wr. 759 . See p. 223.

Variety variegatum Gr. Wr. 3450. See P. exiguiflorum, p. 221.

95. Panicum distichum Lam. variety pilosum Sw. Wr. 3451. See P. pilosum, p. 225.

96. Panicum maximum Jacq. See p. 224.

97. Panicum virgatum L. variety cubense. Wr. a. 1865. (183). See p. 227.

98. Panicum rudgei R. S. Wr. a. 1865 (281). See P. hirtivaginum, p. 223.

99. Panicum hirsutum Sw. Wr. a. 1865 (297). See p. 222.

100. Panicum lindenii Gr. See P. glutinosum, p. 222.

101. Panicum pallens Sw. Wr. 750. See Ichnanthus pallens, p. 228. 3468. See Ichnanthus mayarensis, p. 228. 750 posterius (887). See Ichnanthus pallens, p. 228. 
102. Panicum divaricatum L. Wr. 747. See p. 220.

Variety puberulum Gr. Wr. 748. See P. divaricatum, p. 220.

103. Panicum rugelii Gr. Rug. 188; Wr. 3465. See p. 226.

104. Panicum sloanei Gr. Rug. 872; Wr. a. 1865 (269). See p. 226.

105. Panicum martinicense Gr. Wr. 3457. See P. grisebachii, p. 222.

106. Panicum glutinosum Sw. Wr. 757. See p. 222.

107. Panicum rugulosum Trin. variety hirtiglume Gr. Wr. 3455. See P. sellovii, p. 226.

108. Panicum cayennense Lam. Wr. (891). See p. 218.

109. Panicum brevifolium L. Wr. 1538. See P. trichoides, p. 227.

110. Panicum cyanescens Ns. Wr. 3458. See P. parvifolium, p. 225. Wr. 3459. See P. nitidum, p. 224.

111. Panicum tricanthum Ns. Wr. 753. See p. 227.

112. Panicum dichotomum L. variety glabrescens Gr. Wr. 3462. See P. erectifolium, p. 221. Wr. 3463. See P. caerulescens, p. 219; P. leucothrix, p. 224; P. tenue, p. 227; P. wrightianum, p. 228.

Variety nodiflorum Lam. Wr. 3460. See P. lancearium, p. 223. Wr.3461. See P. chrysopsidifolium, p. 218; P. fusiforme, p. 222; P. lancearium, p. 223; P. pauciciliatum, p. 225.

113. Panicum viscidum Ell. Wr. 3467. See P. scoparium, p. 226.

114. Panicum exiguiflorum Gr. Wr. a. 1865. See p. 221.

115. Isachne leersioides Gr. Wr. 755. See p. 208. Wr. 756. See Panicum exiguiflorum, p. 221.

116. Hymenachne myurus P. B. Wr. 3469. See H. amplexicaulis, p. 212.

117. Hymenachne fluviatilis Ns. Wr. 3470. See Sacciolepis vilvoides, p. 213.

118. Hymenachne striata Gr. Wr. a. 1865 (198). See Sacciolepis striata, p. 213.

119. Setaria glauca P. B. Wr. 3472. See Chaetochloa imberbis, p. 230.

Variety imberbis R. S. Wr. a. 1865 (199). See Chaetochloa imberbis, p. 230.

Variety penicillata Gr. Wr. 3473. See Chaetochloa imberbis, p. 230.

120. Setaria onurus Gr. Wr. 3474. See Chaetochloa onurus, p. 230.

121. Setaria setosa P. B. Rug. 880; Wr. a. 1865 (287). See Chaetochloa onurus, p. 230.

122. Pennisetum setosum Rich. Wr. 3475. See p. 232.

123. Gymnothrix domingensis Spreng. Wr. 1547. See Pennisetum domingense, p. 232.

124. Cenchrus "myosuroides Kth." [No specimen found.]

125. Cenchrus echinatus L. Wr. 3476. See Cenchrus viridis, p. 231.

126. Cenchrus distichophyllus Gr. Wr. 3475. See p. 231.

127. Anthephora elegans Schreb. Wr. a. 1865 (308). See A. hermaphrodita, p. 196.

128. Echinolaena Sp. Wr. 760. See Ichnanthus wrightii, p. 229.

129. Arundinella martinicensis Tr. Wr. 3478. See p. 197.

130. Arundinella phragmitoides Gr. Wr. 3479. See A. deppeana, p. 196.

131. Arundinella cubensis Gr. Wr. 1552. See A. peruviana, p. 197.

132. Tricholaena "insularis Gr." See Valota insularis, p. 210.

133. Lappago aliena Spreng. Wr. 3489. See Nazia aliena, p. 196.

134. Manisuris granularis Sw. Wr. 1553. See Hackelochloa granularis, p. 191.

135. Rottboellia impressa Gr. Wr. a. 1865 (201). See Manisuris impressa, p. 191.

136. Andropogon secundus W. Wr. 1559. See Heteropogon contortus, p. 196.

137. Andropogon saccharoides Sw. Wr. 1556. See A. leucopogon, p. 193.

138. Andropogon "Ischaemum L. (Rich. Lind. 1818)." This specimen has not been examined.

139. Andropogon brevifolius Sw. Wr. 1558. See p. 192.

140. Andropogon tener Kth. Wr. 3482. See p. 194.

141. Andropogon gracilis Spreng. Wr. 1557, 3484. See p. 193.

142. Andropogon "scoparius Mich." Rich. See A. gracilis, p. 193.

143. Andropogon fastigiatus Sw. 3483, 3485. See p. 193.

144. Andropogon "nutans L." See Sorghastrum, p. 195. [No specimen found.] 
145. Andropogon setosus Gr. Wr. a. 1865 (208). See Sorghastrum setosum, p. 195.

146. Anatherum domingense R. S. Wr. a. 1865 (202). See Andropogon leucostachys, p. 193.

147. Anatherum bicorne P. B. Wr. 770. See Andropogon bicorne, p. 192.

148. Anatherum macrurum Gr. Wr. 1555. See Andropogon glomeratus, p. 193.

149. Anatherum spathiflorum Gr. Wr. 3481. See Andropogon spathiflorus, p. 194.

150. Anatherum inerme Gr. Wr. 3480. See Andropogon spathiflorus, p. 194.

151. Sorghum halepense Pers. Wr. 3488. See Holcus halepensis, p. 195.

152. Imperata caudata Tr. Wr. 3486. See I. brasiliensis, p. 190.

153. Triscenia ovina Gr. Wr. 756. See p. 198.

154. Paratheria prostrata Gr. Wr. a. 1865 (207). See p. 232.

\section{GRASSES OF SAUVALLE'S FLORA CUBANA. ${ }^{a}$}

2721. Leersia monandra Sw. 731. See Homalocenchrus monandrus, p. 235.

2722. Leersia hexandra Sw. 3484. See Homalocenchrus hexandrus, p. 234.

2723. Oryza sativa L. 3838. See p. 234.

2724. Caryochloa bahiensis Steud. 3813. See Luziola bahiensis, p. 234.

2725. Uniola paniculata L. 3823. See p. 245.

2726. "Uniola virgata Gris" Rugel. See Uniola virgata, p. 245.

2727. Eragrostis excelsa Gris. 3425. See p. 244.

2728. Eragrostis nitida Chapm. 3423. See E. elliottii, p. 244.

2729. Eragrostis sudans Gris. 3422. See E. glutinosa, p. 244.

2730. Eragrostis ciliaris Link. 1550. See p. 243.

2731. Eragrostis poaeoides Beauv. 745, 3824. See E. tephrosanthes, p. 245.

2732. Eragrostis reptans Nees. 3826. See E. hypnoides, p. 244.

2733. Eragrostis bahiensis Schrad. 3424. See E. cubensis," p. 243.

2734. Eragrostis pilifera Benth. 3825. See E. cubensis, p. 243.

2735. Vilfa virginiana Beauv. 3830. See Sporobolus virginicus, p. 238.

2736. Vilfa indica Steud. 1537, 3829. See Sporobolus indicus, p. 237.

2737. Vilfa jacquemontii Kth. 3426. See Sporobolus indicus, p. 237.

2738. Vilfa arguta Nees. 3828. See Sporobolus argutus, p. 237.

2739. Vilfa purpurascens Beauv. 3427. See Sporobolus cubensis, p. 237, and S. purpurascens, p. 238.

2740. Poa airoides Kth. 3827. See Eragrostis airoides, p. 243.

2741. Arthrostylidium cubense Rupr. 3809, 3811. See p. 246.

2742. Arthrostylidium sp.? 3810. See A. urbanii, p. 246.

2743. Arthrostylidium sp.? 3808. See A. distichum, p. 246.

2744. Arthrostylidium sp. (sine numero). See A. capillifolium, p. 246.

2745. Arthrostylidium fimbriatum Gris. 1554. See p. 246.

2746. Arthrostylidium capillifolium Gris. 738. See p. 246.

2747. Gynerium saccharoides Kth. 1560, 3477. See G. sagittatum, p. 242.

2748. Leptochloa fascicularis Gray. 3812, 3822. See p. 241.

2749. Leptochloa virgata Beauv. 741, 3436. See p. 242.

2750. Leptochloa mucronata Kth. 740. See p. 241.

2751. Muhlenbergia spicata Munn. 3894. See Gramen sp., p. 246.

2752. Muhlenbergia capillaris Trin. 3836. See p. 237.

2753. Aristida scabra Kth. 3835. See p. 236.

2754. Aristida purpurascens Poir. 3432. See A. erecta, p. 236.

2755. Aristida dispersa Trin. 737. See A. mohrii, p. 236. 736. See A. curtifolia, p. 235. 3430, 3431. See A. refracta, p. 236. 3343.b See A. mohrii, p. 236.

$a$ See footnote, page 184 .

$b$ The discrepancies in numbers are doubtless due to typographical errors in Sauvalle's list. 
2756. Reimaria acuta Flügge. 3437. See Reimarochloa brasiliensis, p. 198.

2757. Reinaudia filiformis Kth. 3428. See Reynaudia filiformis, p. 235.

2758. Eleusine indica Gaertn. 744. See p. 241.

2759. Dactyloctenium aegyptiacum Willd. 3831. See D. aegyptium, p. 241.

2760. Cynodon dactylon Pers. (sine numero). See Capriola dactylon, p. 238.

2761. Chloris ciliata Sw. 743. See p. 239.

2762. Chloris petraea Thunb. 3719. See p. 240.

2763. Chloris radiata Sw. 742. See p. 240.

2764. Chloris brevigluma sp. nov. 1848 p. p. See Chloris cruciata, p. 239.

2765. Chloris cruciata Sw. 1548 p. p., 1549. See C. eleusinoides, p. 239.

2766. Chloris beyrichiana Kth. 3819. See C. eleusinoides, p. 239.

2767. Chloris eleusinoides Gris. 3818. See p. 239.

2768. Bouteloua humboldtiana Gris. 739 p. p., 3815. See B. americana, p. 240.

2769. Bouteloua porphyrantha spec. nov. 739 p. p. 734, 3816. See B. americana, p. 240.

2770. Achlaena piptostachya Gris. 3487. See p. 235.

2771. Tricuspis simplex Gris. 1551. See Leptochloa spicata, p. 241.

2772. Olyra strephioides Gris. 3435. See Mniochloa strephioides, p. 233.

2773. Olyra pineti Wr. 1536. See Lithachne pineti, p. 233.

2774. Olyra pauciflora Sw. 732. See Lithachne pauciflora, p. 233.

2775. Olyra latifolia L. 746. See p. 233.

2776. Strephium? pulchellum sp. nov. 3448. See Mniochloa pulchella, p. 233.

2777. Milium lanatum R. \& Sch. 3429. See Leptocoryphium lanatum, p. 207.

2778. Paspalum conjugatum Berg. 767. See p. 201.

2779. Paspalum rupestre Nees. 3445. See p. 206.

2780. Paspalum nanum Wr. 3842. See p. 204.

2781. Paspalum distichum L. 3854? See P. vaginatum, p. 206.

Variety vaginatum 1546. See P. vaginatum, p. 206, and P. distichum, p. 202.

2782. Paspalum alterniflorum Rich? 3841. See p. 200.

2783. Paspalum filiforme Sw. 769. See p. 202.

2784. Paspalum pulchellum Kth. 3439. See p. 205.

2785. Paspalum notatum Flügge. 3438. See p. 204 and P. minus, p. 203.

2786. Paspalum dissectum L. 3440. See p. 202.

2787. Paspalum setaceum Mx. 3442. See P. rigidifolium, p. 205.

2788. Paspalum caespitosum Flügge 3443, 3444. See p. 201.

2789. Paspalum leucocheilum sp. nov. See P. virgatum, p. 206.

2790. Paspalum papillosum Spr.? 3844, p. p. See p. 204.

2791. Paspalum clavuliferum sp. nov. 3444 p. p. See p. 201.

2792. Paspalum decumbens Sw. 3851. See.P. pedunculatum, p. 205.

2793. Paspalum virgatum L. 3446. See p. 206. 3840. See P. millegrana, p. 203.

2794. Paspalum plicatulum Mx. 768, 3839. See p. 205. 3843. See P. elatum, p. 202.

2794. Paspalum densum Poir. 3447. See p. 202.

2795. Paspalum paniculatum L. 766. See p. 204.

2796. Paspalum rottboellioides sp. nov. 3864. See p. 205.

2797. Paspalum hemicryptum sp. nov. 3847. See p. 203.

2798. Paspalum caudicatum sp. nov. 3866. See P. nanum, p. 204.

2799. Paspalum swartzianum Flügge? 3848. See Paspalum sp., p. 206.

2800. Paspalum compressum Nees. 3849. See Axonopus compressus, p. 207.

2801. Panicum filiforme L. 1544. See Syntherisma filiformis, p. 209, and S. leucocoma, p. 209.

2802. Panicum horizontale Meyer. 764. See Syntherisma digitata, p. 209, and S. sanguinalis, p. 209. 3883. See Syntherisma sanguinalis, p. 209.

2803. Panicum sclerochloa Trin? 3859. See Mesosetum wrightii, p. 211.

2804. Panicum rottboellioides Kth. 3449. See Mesosetum rottboellioides, p. 211. 
2805. Panicum platyphyllum Munro. 3441, 3867. See Brachiaria plantaginea, p. 212.

2806. Panicum paspaloides Pers. 761. See Panicum geminatum, p. 222.

2807. Panicum colonum L. 752. See Echinochloa colona, p. 213.

2808. Panicum crus-galli L. 3879. See Echinochloa walteri, p. 213.

2809. Panicum prostratum Lam. 762, 3857. See P. reptans, p. 225.

2810. Panicum grossarium L. 3869. See P. adspersum, p. 217.

2811. Panicum laxum Sw. 759, 3862. See p. 223.

2812. Panicum mayarense sp. nov. 3468 p. p. See Ichnanthus mayarensis, p. 228.

2813. Panicum amphistemon sp. nov. 3464. See Alloteropsis amphistemon, p. 211.

2814. Panicum distantiflorum Rich. 3452. See p. 220.

2815. Panicum diffusum Sw. 1540, 3877. See p. 220.

2816. Panicum fuscum Sw. 754. See P. fasciculatum, p. 221.

2817. Panicum molle Sw. 1545. See P. numidianum, p. 224.

2818. Panicum oryzoides Sw. 3466. See P. zizanioides, p. 228.

2819. Panicum stenodes Gris. 3860. See P. chloroticum, p. 218. 3870. See P. tenerum, p. 227. 3871. See p. 227.

2820. Panicum proliferum Lam. 3456, 3861. See P. chloroticum, p. 218.

2821. Panicum durum Gris. 1539, 3868. See Alloteropsis dura, p. 211.

2822. Panicum distichum Lam. 3451. See P. pilosum, p. 225.

2823. Panicum agrostoides Muhl. 3862. See P. condensum, p. 219.

2824. Panicum maximum Jacq. See p. 224.

2825. Panicum virgatum L. 3873. See P. virgatum cubense, p. 227.

2826. Panicum altissimum Mey. 3872. See P. megiston, p. 224.

2827. Panicum rudgei R. S.? 758. See P. hirtivaginum, p. 223.

2828. Panicum divaricatum L. 747, 748. See p. 220. 3465. See P. rugelii, p. 226.

2829. Panicum sloanei Gris. 3878. See p. 226.

2830. Panicum martinicense Gris. 749. See P. compactum, p. 219. 3457. See P. grisebachii, p. 222.

2831. Panicum lasianthum Trin. 3455, 3855. See P. sellovii, p. 226.

2832. Panicum glutinosum Sw. 757. See p. 222.

2833. Panicum cayennense Lam? (Sine numero). See p. 218.

2834. Panicum dichotomum L. 3460. See P. lancearium, p. 223. 3461. See P. chrysopsidifolium, p. 218, P. fusiforme, p. 222, P. lancearium, p. 223, and P. pauciciliatum, p. 225. 3462. See P. erectifolium, p. 221. 3463. See P. leucothrix, p. 224, P. caerulescens, p. 219, P. tenue, p. 227, and P. wrightianum, p.228. 3874. SeeP. acuminatum, p.217. 3875. SeeP. polycaulon, p. 225 . P. strigosum, p. 227. 3876. See P. pauciciliatum, p. 225. 3453. See P. fusiforme, p. 222, P. chrysopsidifolium, p. 218, and P. neuranthum, p. 224. 3454. See P. chrysopsidifolium, p. 218, and P. fusiforme, p. 222.

2835. Panicum brevifolium L. 1538. See P. trichoides, p. 227.

2836. Panicum cyanescens L. 3458. See P. parvifolium, p. 225. 3459. Seg P. nitidum, p. 224.

2837. Panicum microcarpum Muhl. 753. See P. trichanthum, p. 227.

2838. Panicum viscidum Ell. 3467. See P. scoparium, p. 226.

2839. Panicum pallens Sw.750. See Ichnanthus pallens, p. 228. 3882. See Ichnanthus nemorosus, p. 228.

2840. Panicum nemorosum Sw. 3858, 3881. See Ichnanthus nemorosus, p. 228.

2841. Panicum stoloniferum Poir? 3880. See Ichnanthus wrightii, p. 229.

2842. Panicum amplexicaule Rudge. 3863. See Hymenachne auriculata, p. 212.

2843. Panicum gibbum Ell. 3885. See Sacciolepis striata, p. 213.

2844. Panicum vilvoides Trin. 3470. See Sacciolepis vilvoides, p. 213.

2845. Hymenachne myurus Beauv. 3469. See H. amplexicaulis, p. 212.

2846. Eriochloa punctata Hamilt. 1542. See p. 208.

2847. Eriochloa annulata Kth? 3886. See Eriochloa ramosa, p. 208. 
2848. Chamaerhaphis parvigluma Munro. 3909. See Paratheria prostrata, p. 232.

2849. "Orthopogon hirtellus R. Br." See Oplismenus hirtellus, p. 229.

2850. Orthopogon setarius Spreng. 1593. See Oplismenus hirtellus, p. 229.

2851. Orthopogon loliaceus Spreng. 751. See Oplismenus hirtellus, p. 229.

2852. Setaria glauca Beauv. 3888. See Chaetochloa imberbis penicillata, p. 230.

2853. Setaria setosa Beauv. 3474, 3487. See Chaetochloa onurus, p. 230.

2854. Pennisetum setosum Rich. 3471. See p. 232.

2855. Gymnothrix domingensis Spreng. 1547. See Pennisetum domingense, p. 232.

2856. Stenotaphrum americanum Schrank. 3490. See S. secundum, p. 232.

2857. Isachne leersioides Gris. 1547. See p. 208.

2858. Cenchrus viridis Spreng. 3889. See p. 231.

2859. Cenchrus tribuloides L. 3476. See Cenchrus carolinianus, p. 231 and C. viridis, p. 231.

2860. Cenchrus distichophyllus Gris. 3475. See p. 231.

2861. Anthephora elegans Schreb. 3870. See A. hermaphrodita, p. 196.

2862. Lappago racemosa Willd. 3489. See Nazia aliena, p. 196.

2863. Triscenia ovina Gris. 756. See p. 198.

2864. Arundinella brasiliensis Radd. 1552. See A. peruviana, p. 197.

2865. Arundinella phragmatoides Gris. 3479. See A. deppeana, p. 196.

2866. Arundinella martinicensis Gris: 3478. See p. 197.

2867. Tricholena insularis Gris. 1541. See Valota insularis, p. 210.

2868. Rottboellia impressa Gris. 3904. See Manisuris impressa, p. 191.

2869. Rottboellia filifolia. Sp. nov. 3905. See Manisuris loricata, p. 191.

2870. Manisuris granularis Sw. 1553. See Hackelochloa granularis, p. 191.

2871. Andropogon contortus L. 1559. See Heteropogon contortus, p. 196.

2872. Andropogon saccharoides Sw. 1556. See A. leucopogon, p. 193.

2873. Andropogon alopecuroides L. 3903. See Erianthus saccharoides, p. 190.

2874. Andropogon halepensis Sibth. 3488. See Holcus halepensis, p. 195.

2875. Andropogon nutans L. 3896. See Sorghastrum francavillanum, p. 195. 3897. See Sorghastrum setosum, p. 195.

2876. Andropogon leucostachyus Kth. 3900. See p. 193.

2877. Andropogon virginicus L. 3901. See p. 194.

2878. Andropogon spathiflorum Kth. 3481. 3480. See p. 194.

2879. Andropogon macrouros Mx. 1555. See A. glomeratus, p. 193.

2880. Andropogon bicornis L. 770. See p. 192.

2881. Andropogon tener Kth. 1558? See p. 194, and A. brevifolius, p. 192. 3482. See p. 194.

2882. Andropogon brevifolius Sw. 1558. See p. 192.

2883. Andropogon gracilis Spreng. 3480. See p. 193.

2884. Andropogon sp. 3898. See A. cubensis, p. 192.

2885. Andropogon wrightii Munro, 293, 263, 3895. See Rhaphis pauciflora, p. 195.

2886. Andropogon fastigiatus Sw. 3483. See p. 193.

2887. Andropogon sp. 3889. See Cenchrus viridis, p. 231.

2888. Andropogon sp. 3892, 3893. See Trachypogon filifolius, p. 191.

2889. Andropogon sp. 3891. See A. semiberbis, p. 194.

2890. Imperata caudata Trin. 3486. See I. brasiliensis, p. 190.

2891. Perotis? cubana spec. nov. 735. See Chaetium cubanum, p. 232. 


\section{GRASSES COLLECTED IN CUBA BY WRIGHT, ARRANGED BY NUMBERS.}

731. Homalocenchrus monandrus.

732. Lithachne pauciflora.

733. Pharus glaber.

734. Bouteloua americana.

735. Chaetium cubanum.

736. Aristida curtifolia.

737. Aristida mohrii.

738. Arthrostylidium capillifolium.

739. Bouteloua americana.

740. Leptochloa mucronata. ${ }^{a}$ Leptochloa virgata.

741. Leptochloa mucronata. Leptochloa virgata.

742. Aristida mohrii.

- Chloris radiata.

743. Chloris ciliata.

744. Eleusine indica.

745. Eragrostis tephrosanthes.

746. Olrya latifolia.

747. Panicum divaricatum.

748. Panicum divaricatum.

749. Panicum compactum.

750. Ichnanthus pallens.

751. Oplismenus hirtellus.

752. Echinochloa colona.

753. Panicum tricanthum.

754. Panicum fasciculatum.

755. Panicum exiguiflorum. Isachne leersioides.

756. Triscenia ovina.

Panicum exiguiflorum.

757. Panicum glutinosum.

758. Panicum hirtivaginum.

759. Panicum laxum.

760. Ichnanthus wrightii.

761. Panicum geminatum.

762. Panicum reptans.

763. Panicum reptans.

Axonopus compressus.

764. Syntherisma digitata.

Syntherisma sanguinalis.

765. Axonopus compressus.

766. Paspalum paniculatum.

767. Paspalum conjugatum.

768. Paspalum plicatulum.

769. Paspalum filiforme.

770. Andropogon bicornis.

1536. Lithachne pineti.

1537. Sporobolus indicus.

1538. Panicum trichoides.
1539. Alloteropsis dura.

1540. Panicum diffusum.

1541. Valota insularis.

1542. Eriochloa punctata.

1543. Oplismenus hirtellus.

1544. Syntherisma filiformis.

Syntherisma leucocoma.

1545. Panicum numidianum.

1546. Paspalum distichum.

Paspalum vaginatum.

1547. Isachne leersioides.

Pennisetum domingense.

1548. Chloris cruciata.

Chloris eleusinoides.

1549. Chloris cruciata.

Chloris eleusinoides.

1550. Eragrostis ciliata. ru

1551. Leptochloa spicata.

1552. Arundinella peruviana.

1553. Hackelochloa granularis.

1554. Arthrostylidium fimbriatum.

1555. Andropogon bicornis.

Andropogon glomeratus.

1556. Andropogon leucopogon.

1557. Andropogon gracilis.

1558. Andropogon brevifolius. Andropogon tener.

1559. Alloteropsis dura. Heteropogon contortus.

1560. Gynerium sagittatum.

1593. Oplismenus hirtellus.

1848. Chloris cruciata.

2823. Uniola paniculata.

2829. Sporobolus indicus.

2830. Sporobolus virginicus.

3422. Eragrostis glutinosa.

Sporobolus cubensis.

3423. Eragrostis elliottii.

3424. Eragrostis cubensis.

3425. Eragrostis excelsa.

3426. Sporobolus indicus.

3427. Sporobolus cubensis.

Sporobolus purpurascens.

3428. Reynaudia filiformis.

3429. Leptocoryphium lanatum.

3430. Aristida refracta.

3431. Aristida refracta.

3432. Aristida erecta.

3433. Aristida mohrii.

3434. Homalocenchrus hexandrus.

$a$ Two or more species when here listed under one number were all distributed under this number by Wright. 
3435. Mniochloa strephioides.

3436. Leptochloa virgata.

3437. Reimarochloa brasiliensis.

3438. Paspalum notatum. Paspalum minus.

3439. Paspalum pulchellum.

3440. Paspalum dissectum.

3441. Brachiaria plantaginea.

3442. Paspalum rigidifolium.

3443. Paspalum arenarium.

Paspalum caespitosum.

3444. Paspalum caespitosum.

Paspalum clavuliferum.

Paspalum papillosum.

Paspalum rupestre.

3445. Paspalum rupestre.

3446. Paspalum virgatum.

Paspalum virgatum schreberianum.

3447. Paspalum densum.

3448. Mniochloa pulchella.

3449. Mesosetum rottboellioides.

3450. Panicum exiguiflorum.

3451. Panicum pilosum.

3452. Panicum distantiflorum.

3453. Panicum chrysopsidifolium.

Panicum fusiforme.

Panicum neuranthum.

3454. Panicum chrysopsidifolium.

Panicum fusiforme.

3455. Panicum sellovii.

3456. Panicum chloroticum.

3457. Panicum grisebachii.

Panicum pilosum.

3458. Panicum parvifolium.

3459. Panicum nitidum.

3460. Panicum lancearium.

3461. Panicum chrysopsidifolium.

Panicum fusiforme.

Panicum lancearium.

Panicum pauciciliatum.

3462. Paspalum densum.

Panicum erectifolium.

Panicum sellovii.

3463. Panicum caerulescens.

Panicum leucothrix.

Panicum tenue.

Panicum wrightianum.

3464. Alloteropsis amphistemon.

3465. Panicum rugelii.

3466. Panicum zizanioides.

3467. Panicum scoparium.

3468. Ichnanthus mayarensis.

3469. Hymenachne amplexicaulis.

3470 . Sacciolepis vilvoides.
3471. Pennisetum setosum.

3472. Chaetochloa imberbis.

3473. Chaetochloa imberbis.

3474. Chaetochloa onurus.

3475. Cenchrus distichophyllus.

Pennisetum setosum.

3476. Cenchrus viridis.

Cenchrus carolinianus.

3477. Gynerium sagittatum.

3478. Arundinella martinicensis.

3479. Arundinella deppeana.

3480. Andropogon gracilis. Andropogon spathiflorus.

3481. Andropogon spathiflorus.

3482. Andropogon tener.

3483. Andropogon fastigiatus.

3484. Andropogon gracilis.

3485. Andropogon fastigiatus.

3486. Imperata brasiliensis.

3487. Chaetochloa onurus.

Achlaena piptostachya.

3488. Holcus halepensis.

3489. Nazia aliena.

3490. Stenotaphrum secundum.

3719. Chloris petraea.

3808. Arthrostylidium distichum.

3809. Arthrostylidium cubense.

3810. Arthrostylidium urbanii.

3811. Arthrostylidium cubense.

3812. Leptochloa fascicularis.

3813. Luziola bahiensis. •

3814. Capriola dactylon.

3815. Bouteloua americana.

3816. Bouteloua americana.

3817. Chloris petraea.

3818. Chloris eleusinoides.

3819. Chloris eleusinoides.

3821. Dactyloctenium aegyptium.

3822. Leptochloa fascicularis.

3823. Uniola paniculata.

3825. Eragrostis cubensis.

3826. Eragrostis hypnoides.

3827. Eragrostis airoides.

3828. Sporobolus argutus.

3829. Sporobolus indicus.

3830. Sporobolus virginicus.

3831. Aristida refracta.

Dactyloctenium aegyptium.

3832. Aristida refracta.

3833. Aristida refracta.

3834. Aristida refracta.

3835. Aristida scabra.

3836. Muhlenbergia capillaris.

3837. Homalocenchrus hexandrus. 
3838. Oryza sativa.

3839. Paspalum plicatulum. Paspalum pulchellum.

3840. Paspalum millegrana.

3841. Paspalum alterniflorum.

3842. Paspalum nanum.

3843. Paspalum elatum.

3844. Paspalum papillosum.

3845. Paspalum propinquum.

3846. Paspalum glabrum.

3847. Paspalum hemicryptum.

3848. Paspalum sp.

3849. Axonopus compressus.

3850. Axonopus compressus.

3851. Paspalum pedunculatum.

3852. Panicum diffusum.

3853. Brachiaria plantaginea.

3854. Paspalum vaginatum. Reimarochloa oligostachya.

3855. Panicum sellovii.

3856. Panicum laxum.

3857. Panicum reptans.

3858. Ichnanthus nemorosus.

3859. Mesosetum wrightii.

3860. Panicum chloroticum.

Panicum diffusum.

Panicum hirtivaginum.

Panicum tenerum.

3861. Panicum chloroticum.

3862. Panicum condensum.

Panicum laxum.

3863. Hymenachne auriculata.

Panicum condensum.

Panicum laxum.

3864. Paspalum rottboellioides.

3865. Panicum cayennense.

- 3866. Paspalum nanum.

3867. Brachiaria plantaginea.

3868. Alloteropsis dura.

3869. Panicum adspersum.

3870. Anthephora hermaphrodita.
3870. Panicum distantiflorum. Panicum tenerum.

3871. Panicum stenodes.

3872. Panicum megiston.

3873. Panicum virgatum cubense.

3874. Panicum acuminatum.

3875. Panicum polycaulon.

Panicum strigosum.

3876. Panicum pauciciliatum.

3877. Panicum diffusum.

Panicum exiguiflorum.

3878. Panicum sloanei.

3879. Echinochloa walteri. \{ chomseres

3880. Ichnanthus wrightii.

3881. Ichnanthus nemorosus.

3882. Ichnanthus nemorosus.

3883. Syntherisma sanguinalis

3884. Syntherisma villosa.

3885. Sacciolepis striata.

3886. Eriochloa ramosa.

3887. Chaetochloa onurus.

3888. Chaetochloa imberbis penicillata.

3889. Cenchrus viridis.

3890. Anthephora hermaphrodita.

3891. Andropogon semiberbis.

3892. Trachypogon filifolius.

3893. Trachypogon filifolius.

3894. Unidentified.

3895. Rhaphis pauciflora.

3896. Sorghastrum francavillanum.

3897. Sorghastrum setosum.

3898. Andropogon cubensis.

3899. Andropogon nashianus.

3900. Andropogon leucostachys.

3901. Andropogon virginicus.

3902. Andropogon bicornis.

3903. Erianthus saccharoides.

3904. Manisuris impressa.

3905. Manisuris loricata.

3906. Paratheria prostrata.

3909. Paratheria prostrata. 


\section{LIST OF NEW GENERA AND SPECIES AND NEW NAMES.}

Alloteropsis amphistemon (Wright) Hitchc..................... 211

Panicum amphistemon Wright.

Alloteropsis dura (Griseb.) Hitchc.............................. 211

Panicum durum Griseb.

Alloteropsis semialata (R. Br.) Hitchc............................ 210

Panicum semialatum $\mathrm{R}$. Br.

Andropogon nashianus Hitch. sp. nov ........................ 193

Aristida curtifolia Hitchc. sp. nov . . . . . . . . . . . . . . . . . . . . 235

Aristida erecta Hitchc. sp. nov ............................ 236

Brachiaria plantaginea (Link) Hitche ......................... 212

Panicum plantagineum Link.

Chaetium cubanum (Wright) Hitchc.... . . . . . . . . . . . . . . . . . . 232

Perotis? cubana Wright.

Eragrostis cubensis Hitchc. sp. nov........................... 243

Eriochloa filifolia Hitchc. sp. nov ........................... 207

Eriochloa subglabra (Nash) Hitchc........................... 208

Monachne subglabra Nash.

Ichnanthus mayarensis (Wright) Hitchc........................ 228

Panicum mayarense Wright.

Ichnanthus wrightii Hitchc. sp. nov........................ 229

Luziola bahiensis (Steud.) Hitchc... . . . . . . . . . . . . . . . . . . . . . 234 Caryochloa bahiensis Steud.

Mesosetum rottboellioides (H. B. K.) Hitchc..................... 211 Panicum rottboellioides $\mathrm{H}$. B. $\mathrm{K}$.

Mesosetum sclerochloa (Trin.) Hitchc...................... 212 Panicum sclerochloa Trin.

Mesosetum wrightii Hitchc. sp. nov............................ 211

Panicum caerulescens Hack. in herb.... . . . . . . . . . . . . . . . . . . . 219

Panicum fusiforme Hitchc . . . . . . . . . . . . . . . . . . . . . . . . . . 222

Panicum neuranthum variety ramosum Griseb. 1866, not P. ramosum L. 1767.

Panicum hirtivaginum Hitchc. sp. nov ......................... 223

Paspalum ciliiferum (Nash) Hitchc........................... 201

Dimorphostachys ciliifera Nash.

Reimarochloa Hitchc. gen. nov. (type, Reimaria acuta Flügge)........... 198

Reimarochloa acuta (Flügge) Hitchc... . . . . . . . . . . . . . . . . 198 Reimaria acuta Flügge.

Reimarochloa brasiliensis (Spreng.) Hitchc....................... 198 Agrostis brasiliensis Spreng.

Reimarochloa oligostachya (Munro) Hitchc...................... 199 Reimaria oligostachya Munro.

Sorghastrum francavillanum (Fourn.) Hitchc...................... 195 Andropogon francavillanus Fourn. 
Sorghastrum setosum (Griseb.) Hitchc Andropogon setosus Griseb.

Sporobolus cubensis Hitchc. sp. nov

Syntherisma aequiglumis (Hack. \& Arech.) Hitchc.

210 Panicum aequiglume Hack. \& Arech.

Trachypogon filifolius (Hack.) Hitchc

191 Trachypogon polymorphus $\beta$ filifolius Hack. 


\section{INDEX OF SPECIES.}

[Page number of principal entries in bold-face type. Synonyms in italics.]

\begin{tabular}{|c|c|c|}
\hline & Page. & A th not li: 1. \\
\hline Achlaena piptostachy & $\ldots 235$ & Arthrostylidium angustifolium.. \\
\hline Agrostis brasiliensis. & 198 & capillifolium ............... \\
\hline cruciata......... & 239 & cubense. . . . . . . \\
\hline indica.......... & 237 & distichum..... \\
\hline purpurascens.. & 238 & fimbriatum.... . \\
\hline radiata ......... & 240 & sarmentosum... \\
\hline virginica.......... & 238 & urbanii.......... \\
\hline Alloteropsis amphisten & 211 & Arundinella brasitiensis... \\
\hline distachya .......... & 210 & crinita.................. \\
\hline dura........... & 211 & cubensis........ \\
\hline semialata...... & 210 & 196 \\
\hline Anatherum inerme... & 194 & hispida...... \\
\hline spathiflorum...... & 194 & martinicensis ... \\
\hline Andropogon avenaceum & 195 & pallida........... \\
\hline barbatum.......... & .. 240 & peruviana....... \\
\hline bicornis........ & 192,193 & phragmitoides.... \\
\hline brevifolius....... & 192,194 & A sperella digitaria.... \\
\hline contortus...... & .. 196 & Axonopus compressus... \\
\hline & 192 & americana.... \\
\hline sis...... & 193 & ha.......... \\
\hline ......... & 198 & humboldtiana........ \\
\hline francavillanum... & .. 195 & litigiosa.............. \\
\hline glomeratus...... & 192,193 & porphyrantha..... \\
\hline & $\ldots \quad 193$ & Brachiaria plantaginea.. \\
\hline haleper & 195 & platyphylla .......... \\
\hline hispidus......... & 197 & tus..... \\
\hline & 194 & ctylón....... \\
\hline$\ldots \ldots$ & 210 & ahiensis.... \\
\hline leucopogon....... & $\therefore \quad 193$ & Cenchrus carolinianus... \\
\hline leucostachys.... & 193,194 & chophyllus..... \\
\hline macrourum....... & -. 193 & atus......... \\
\hline ashianus....... & 193 & nularis......... \\
\hline tans........... & 195 & $u s \ldots . . . . . .$. \\
\hline parius........ & 193 & Loides . . . . . . . . \\
\hline undus.......... & 196 & viridis .............. \\
\hline semiberbis....... & 194 & Chaetium cubanum.... \\
\hline setosus............ & 195 & festucoides........... \\
\hline spathiflorus..... & 194 & Chaetochloa hispida.... \\
\hline is....... & 194 & imberbis............. \\
\hline subtenuis........ & $\ldots 194$ & penicillata........ \\
\hline tener.................. & 192,194 & 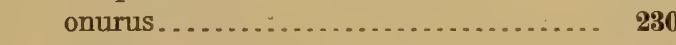 \\
\hline inicus........ & $\ldots 194$ & purpurascens......................... \\
\hline wrightii............ & 195 & setosa................. \\
\hline Anthephora elegans... & 196 & verticillata.............. \\
\hline arodita.... & 196 & Chamaeraphis parvigluma.... \\
\hline Aristida americana.... & 240 & Chloris barbata.............. \\
\hline & 235 & brevigluma.......... \\
\hline dispersa.......... & 240 & 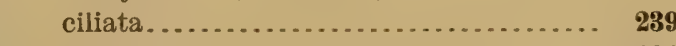 \\
\hline erecta............. & 236 & cruciata. . . . . . \\
\hline gyrans.............. & 236 & elegans. . . . . \\
\hline hrii........... & 236 & eleusinoides. . . . . . . . . . . . . . . . . \\
\hline 1stris. . . . . . . . & 236 & vestita................ \\
\hline refracta.......... & 236 & paraguaiensis........... \\
\hline scabra........... & 236 & petraea.................... \\
\hline
\end{tabular}


Page.

Chloris radiata ........................ $\quad \mathbf{2 4 0}$ swartziana........................ 240

Cinna glomerata........................ 193

Coix lacryma-jobi ...................... $\quad 190$

Cynodon dactylon.

Cynosurus aegyptius. indicus.... virgatus.

Digitaria foliosa

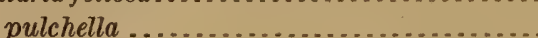

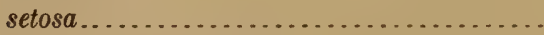

Dimorphostachys ciliifera................. pedunculata.

Echinoch crusgalli ............................ 213 walteri........................... 213

Eleusine indica........................ 241 mucronata....................... 241

Eragrostis airoides........................ $\quad 243$ bahiensis......................... 243 berteroiana....................... 243 ciliaris............................... 243

cubensis.......................... 243, 244

elliottii.......................... 244

excelsa............................. 244

glutinosa......................... 244

hypnoides....................... 244

macropoda......................... 244

nitida.......................... 244

pilosa.............................. 245

plumosa........................... $\quad 245$

reptans ............................ 244

sudans ......................... 237, 244

tenella............................. 245

plumosa....................... 245

tephrosanthes...................... $\mathbf{2 4 5}$

Erianthus saccharoides................. 190

Eriochloa annulata..................... 208

filifolia.......................... 207

punctata............................ 208

subglabra...................... 208

ramosa........................... 208

subglabra......................... 208

Eustachys petraea...................... 240

Festuca fascicularis. . . . . . . . . . . . .......... 241

Goldbachia mikani...................... 197

Gymnothrix domingensis..................... 232

Gynerium saccharoides...................... 242

sagittatum...................... $\quad \mathbf{2 4 2}$

Hackelochloa granularis.................. 191

Heteropogon contortus..................... 196 secundus........................... 196

Holcus halepensis. . . . . . . . . . . . . . . . . . 195 sorghum........................ 195 striatus........................... 213

Homalocenchrus hexandrus. . . . . . . . . .... 234 monandrus....................... 2835

Hymenachnie amplexicaulis.............. 212 auriculata....................... 212

fluviatilis........................ 213

Hypogynium spathiflorum.................. 194

Ichnanthus mayarensis................ 228, 229

nemorosus........................... 228

pallens.............................. 228

wrightii...................... 229
Page.

Imperata brasiliensis.................... 190

Isachne leersioides . . . . . . . . . . . . . . . . . . . 198, 208

Ischaemum rugosum. . . . . . . . . . . . . . . . . . 191 secundum.......................... 232

Lappago aliena........................... 196 racemosa........................... 196

Leersia hexandra . ....................... . 234 monandra.......................... 235

Leptochloa fascicularis................. 241

filiformis.......................... 241

mucronata. . . . . . . . . . . . . . . . . 241, 242

perennis......................... 242

spicata............................. 241

virgata. ........................ 241, 242

Leptocoryphium lanatum............... 207

Lithachne axillaris......................... $\quad 233$ pauciflora........................... 238 pineti............................ 283

Luziola alabamensis ...................... 234 bahiensis.......................... $\quad 234$ longivalvula.......................... 234

Manisuris granularis...................... 191 impressa......................... 191 loricata............................ 191

Mesosetum cayennense.................... 211 rottboelloides......................... 211 sclerochloa ......................... 212 wrightii......................... 211

Milium compressum..................... 207 digitatum.......................... 209 punctatum......................... 208 ramosum.

Mniochloa pulchella..................... $\quad 283$ strephioides........................ $\quad 283$

Monachne subglabra...................... 208

Muhlenbergia capillaris.................. $\quad 288$ spicata.......................... 246

Nazia aliena............................ 196

Olyra axillaris............................ 233

latifolia........................... $\quad \mathbf{2 8 3}$

pauciflora........................... 283

pineti............................. 233

Opizia stolonifera..................... $\quad \mathbf{2 4 2}$

Oplismenus hirtellus................... $\quad \mathbf{2 2 9}$

Oryza sativa.......................... $\quad 234$

Panicum acuminatum .................. 217

adspersum..................... 217,226

aequiglume....................... 210

agrostidiforme...................... 223, 224

albomarginatum..................... $\quad 227$

altissimum....................... 224

amphistemon....................... 211

amplexicaule.......................... 212

appressum......................... 222

aquaticum......................... 218

auriculatum..................... 212

bambusoides ......................... 220, 221

barbinode........................... 224

bartowense........................ 218

brevifolium....................... 227

brizoides........................... 222

caerulescens .............. 219, 224, 227, 228

caespitosum....................... $\quad 225$

caricoides.......................... 227

cayennense.......................... 218

chaetium........................ 232

chauvinii........................ 220 
Page.

Panicum chloroticum .................. 218

chrysopsidifolium................... 218

colonum :....................... 213

comophyllum....................... 217

compactum....................... 219

condensum. . . . . . . . . . . . . . 212, 219, 223

crusgalli.......................... 213

curvinerve......................... 209

cyanescens........................ 225

dactylon........................... 238

decumbens.......................... 205

diandrum ....................... 223, 224

dichotomiflorum .................... 218

dichotomum nodiflorum............... 219

nodiflorum forma glabrescens ....... 222

diffusum ........................... 220

dissectum......................... 202

distantiflorum..................... 220,227

distichum........................... 225

divaricatum.................. 220, 221, 226

puberulum....................... 220

$\beta$ stenostachyum.................. 221

duchaissingii........................ 210

durum........................... 211

elephantipes........................ 218

equinum.......................... 224, 225

erectifolium........................ $2 \mathbf{2 2 1}$

exiguiflorum ................. 208, 220, 221

fasciculatum..................... 204, 221

filiforme.......................... 209

flavescens........................... 221

floridanum....................... 221

fuscum.......................... 221

fusiforme .......................... $\quad 222$

geminatum........................ $\quad \mathbf{2 2 2}$

geniculatum........................ 230

gibbum............................ 213

glutinosum........................ $\quad 222$

grisebachii......................... 222

grossarium........................ 225, 226

hirsutum ................... 222, 223

hirtellum.......................... 229

hirtivaginum ..................... $\quad 223$

hygrophilum...................... 218

hymenachne..................... 212

illinoniense........................ 221

imberbe.............................. 230

insularum...................... 225, 226

laeve.............................. 224

lanatum.......................... 227

lancearium................... 219, 222, 223

lasianthum......................... 226

laxum..................... 212, 219, 223

variegatum.................... 221

leandri........................... 212

leptochyrium........................ 232

leucophaeum..................... 210

leucothrix................ 219, 224, 227, 228

lindenii........................... 222

maximum......................... $\quad 224$

mayarense......................... 228

megiston.......................... 224

minutiflorum...................... 221

minutulum........................ 228

molle............................. 225

muticum........................ 225
Page.

Panicum myuros.................... 212,213

nemorosum....................... 228

neuranthum................. 219,222, 224

ramosum...................... 222

nitidum.......................... 224

numidianum..................... $\quad 224$

obtusiflorum....................... 222

onurus.......................... 230

oryzoides......................... 228

ovalifolium......................... 227

oxyanthum........................ 198, 199

pallens............................ 228

parvifolium........................ 224, 225

paspalodes........................ 222

pauciciliatum...................... 222,225

penicillatum........................ 230

pilisparsum....................... 225

pilosum............................. $\quad 225$

plantagineum........................ 212

platyphyllum...................... 212

polycaulon ....................... 225,227

polygonatum........................ 223, 224

proliferum....................... 218

pilosum....................... 218

strictum......................... 218

prostratum......................... 225

ramosum.......................... 222

ramuliflorum .................... 223,224

repens........................... $\mathbf{2 2 5}$

reptans.......................... 225

roanokense......................... 219

rottbocllioides...................... 211

rudgei......................... 223

rugelii............................. 226

rugulosum.......................... 226

hirtiglume...................... 226

sanguinale........................... 209

simpsoni..................... 210

sclerochloa........................ 211

scoparium......................... $\quad \mathbf{2 2 6}$

sellovii............................ $\quad 226$

semialatum....................... 210

setarium......................... 229

setosum........................... 231

sintenisii....................... 220

sloanei........................... 226

sphaerocarpon floridanum............. 221

stenodes........................ 220,227

strigosum........................ $\quad 227$

subbarbulatum...................... 224

swartzianum...................... $\quad 227$

tenerum............................ 227

tenue...................... 219,224,227, 228

tenyiculmum...................... 223,224

tricanthum...................... $\quad 227$

trichocondylum...................... 224

trichoides....................... $\quad 227$

tricolor............................. . 221

utawanaeanum.................... 220

valenzuelanum...................... 226

verticillatum ......................... 231

vilvoides............................. 213

virgatum breviramosum.................. 227

cubense...................... 227, 228

obtusum......................... 227

viscidum........................... $\quad 226$ 
Panicum walteri. Page.

wrightianum............... 219, 224, 227, 228

zizanioides.......................... 228

Pappophorum laguroides................. 242

Paratheria prostrata.................... $\quad 232$

Paspalum alterniflorum................. $\quad 200$

angustifolium........................ 203

appressum...................... 222

approximatum.................... 202

arenarium.......................... 201

bakeri............................ 202

caespitosum................... 201,202,206

candidum......................... 198

caudicatum....................... 204

ciliiferum........................... 201

clavuliferum........................ 201

compressum....................... 207

conjugatum......................... 201

debile............................ 201

decumbens............................ 205

densum.......................... 202

denticulatum....................... 203

dissectum....................... 202

distichum. ...................... 198, 199, 202

dolichophyllum....................... 200

elatum.......................... 202

elegans.......................... 205

elongatum.......................... 198

falcula............................. 201

filiforme....................... 202

glabrum........................... 202

helleri........................... 203

hemicryptum.................... 203

horticola.......................... 201

maritima...................... 205

inops............................. 203

lanatum.......................... 207

lentiginosum....................... 203

leuchocheilum...................... 206

lindenianum....................... 204, 206

lineare.............. 203

lividum.......................... 203

longepedunculatum.................. 201

membranaceum..................... 202

millegrana......................... 203

minus........................... 203, 204

nanum............................ 204

neesii............................ 203

notatum........................ 203, 204

paniculatum...................... 204

papillosum................... 201, 204, 205

pedunculatum...................... 205

pittieri............................... 204

platyphyllum...................... 212

plicatulum . . . . . . . . . . . . . . . . . . . 202, 205

propinquum........................ 205

pulchellum ....................... 198, 205

rigidifolium ......................... 205

rottboellioides...................... 205

rupestre........................ 201, 206

simpsoni.......................... 201

swartzianum....................... 202,207

taphrophyllum...................... 204

tristachyon........................... 207

underwoodii......................... 203

vaginatum ............... 198, 199, 202, 206
Paspalum vaginiflorum Page.

villosissimum........................ 201

virgatum......................... 206

glabriusculum.................... 206

schreberianum.................. 206

vulnerans.......................... 203

Paspalus annulatus........................ . 208

Pennisetum domingense.................. 232

setosum........................... 232

Perotis cubana........................... 232

Pharus glaber........................ 234

latifolius.... . . . . . . . . . . . . . . . . . . . 234

parvifolius........................... $\quad 234$

Poa amabilis........................... 245

ciliaris............................... 243

glutinosa........................... 244

hypnoides........................... 244

nitida............................. 244

plumosa.......................... 245

reptans............................ 244

tenella............................. 245

virgata............................ 245

Polydon distichus........................ 240

Polypogon cubensis..................... 235

Poranthera........................... 195

Reimaria acuta ........................ 198

brasiliensis....................... 198

elegans............................ 205

oligostachya...................... 199

Reimarochloa acuta . . . . . . . . . . . . . . . . $\quad 198$

brasiliensis. . . . . . . . . . . . . . . . . . . . . 198

oligostachya........................ 199

Reynaudia filiformis................... $\quad 235$

Rhaphis pauciflora.................... 195

Rottboellia filifolia........................ 191

impressa........................... 191

loricata........................... 191

Saccharum officinarum................. $\quad 190$ sagittatum....................... 242

Sacciolepis myuros.................... $\quad 213$

striata.......................... 213

vilvoides ......................... $\quad \mathbf{2 1 3}$

Schizachyrium gracile...................... 193

semiberbe......................... 194

tenerum............................ 194

Setaria glauca.......................... $\quad 230$

onurus............................ 230

purpurascens...................... 231

Sorghastrum francavillanum . . . . . . . . . . 195

setosum........................... 195

Sorghum halepense ..................... 195

pauciflorum...................... 195

Sporobolus argutus.................... 237

cubensis....................... 237,238

indicus........................... 287

jacquemontii....................... 237

purpurascens....................... 237, 238

virginicus........................... 238

Stenotaphrum secundum ................ $\quad 232$

Stipa capillaris......................... 237

Strephium pulchellum.................... 233

Streptachne cubensis...................... $\quad 236$

scabra............................ $\quad 236$

Syntherisma aequiglumis................ $\quad \mathbf{2 1 0}$

digitata...................... 207, 209

filiformis....................... 209 


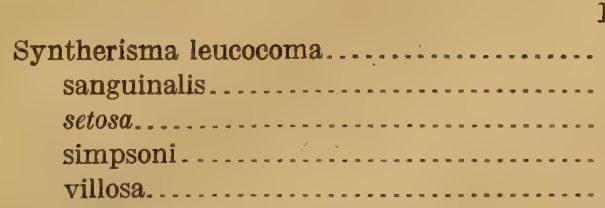

Tricholaena rosea.

Page.

Thysanachne peruviana

scoparia.

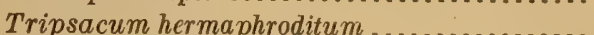

Triscenia ovina............. 196

Uniola paniculata...................... $\mathbf{2 4 5}$

virgata........................ 245

197 Valota insularis..................... 210

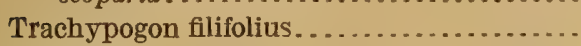

gouini.

191

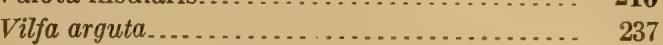

polymorphus filifolius.

domingensis..

237

191

grisebachiana 




Reprinted from the Botanical Gazette, 5I: pp. 300-302 No. 4, April, I9II

\section{ADDITIONS TO THE GRASSES OF CUBA}

Since the publication of the Catalogue of the grasses of $C u b a,{ }^{3}$ several additional species of grasses have been contributed to the National Herbarium by Brother LEón of the Colegio de la Salle, Habana. The following is a list of these:

Manisuris exaltata (L. f.) Kuntze, Rev. Gen. Pl. 2:779. I89I.

Stegosia exaltata Nash, N. Amer. Fl. I7:84. I909.

This species is retained provisionally in Manisuris until the genera of Andropogoneae are more carefully examined.

Sancti Spiritus, León 847 .

ANDROPOGON SQUARROSUs L. f. Suppl. 433. I78I.

Habana, León i 58r. Introduced.

ANDropogon CARiçosus L. Sp. Pl. ed. 2. 2:1480. I763.

Guanabacoa, León 20I3. Introduced.

Sorghastrum agrostoides (Speg.).

Andropogon agrostoides Speg. Pl. Nov. Nonnul. Amer. Austr. Dec. 2:27. 1883.

Sancti Spiritus, León 895.

Paspalum blepharophyllum Nash, in Small Fl. Southeast. U.S. 7I. I903.

Marianao, León, 779.

Paspalum Helleri Nash, Bull. Torrey Club 30:376. I903.

Santiago de Cuba, Leôn 95I.

Paspalum monostachyum (H. B. K.) Vasey, in Chapm. Fl. South. U.S. ed. 2. 665. I889.

Zaza de Tunas, Santa Clara, León 947. The spikelets are smaller than in the typical form.

Paspalum Leoninum Chase, sp. nov.-A low tufted perennial, with narrow leaves mostly crowded at the base, slender nearly naked culms and solitary usually purplish racemes. Culms $15-35 \mathrm{~cm}$. high, very slender, wiry, compressed, ascending or spreading and more or less sinuous, glabrous, the nodes ascending-pubescent; lower sheaths overlapping and keeled, glabrous or sparsely pubescent on the scarious margin and with a few stiff hairs on the auricles, ${ }^{3}$ Hrтснсоск, A. S., Contr. Nat. Herb. I 2 : 183-258. 1909. 
usually but a single leaf about midway on the culm, the sheath with a few scattered long hairs or glabrous; ligule membranaceous, about $0.5 \mathrm{~mm}$. long; blades flat or somewhat involute from a folded base narrower than the summit of the sheath, $3^{-7} \mathrm{~cm}$. long, I-2 $\mathrm{mm}$. wide, more or less curled, glabrous on both surfaces or minutely puberulent on the upper, a few stiff hairs on the margin and rarely on the upper surface, the blade of the uppermost leaf reduced to a mere tip; raceme $2-3.5 \mathrm{~cm}$. long, slightly curved, a few long hairs at the base; spikelets solitary, on very short, flattened, scabrous pedicels, closely imbricated, almost concavo-convex, I. $3^{-1} \cdot 5 \mathrm{~mm}$. long, about $0.7 \mathrm{~mm}$. wide, oval, glabrous; second glume 3-nerved, the sterile lemma with a nerve near either margin, the midnerve suppressed or apparent only at the summit; fruit nearly as large as the spikelet.

Type U.S. National Herbarium no. 618,754; collected August 30, I909, on "Obispo hill, near Sancti Spiritus," by Brother León (no. 950).

This species is most nearly related to Paspalum rupestre Trin., from singlespiked specimens of which it may be distinguished by the more delicate culms and the more closely imbricated, glabrous spikelets, the second glume with the midnerve suppressed.

Paspalum Leoninum is named in honor of Brother LEón, of the Colegio de la Salle, Vedado, Habana, whose collections have added greatly to our knowledge of the grasses of Cuba.

A second collection of this species was made on the Jata Hills, Guanabacoa, September I2, I909, León 949.

Cenchrus myosuroides H. B. K. Nov. Gen. \& Sp. i : i I5. I8I6.

Santiago de Cuba, León 835 .

Gouinia polygama Fourn. Mex. Pl. 2 : I03. I 886.

Cojimar, León 2or4.

ARundo Donax L. Sp. Pl. 8I. I753.

Marianao, León I523. Escaped from cultivation.

Lolium temulentum Arvense (With.) Bab. Man. Brit. Bot. 377. i843. Habana, León $\mathrm{r} 583$. Intrỏduced.

It may be well to record here certain changes in the names of a few species of Panicum listed in the Catalogue, as shown by the recent revision of this group. ${ }^{4}$

Panicum aquaticum Poir. This is a synonym of $P$. dichotomiflorum

Michx. The Cuban species is $P$. elephantipes Nees.

Panicum compactum $\mathrm{Sw} .=$ Lasiacis compacta (Sw.).

${ }^{4}$ Hitchсоск and Chase, Contr. Nat. Herb. I5:I-396. I9Io. 
Panicum distantiflorum Rich. To this species was referred Panicum utowanaeum Scribn. (P. Sintenisii Nash), which proves to be a distinct species. It is represented by two specimens from Triscornia, near Habana, Hitchcock I4I and Tracy 9089.

Panicum divaricatum L. = Lasiacis Divaricata (L.) Hitchc.

Panicum Grisebachii Nash=Lasiacis Grisebachii (Nash).

Panicum hirtivaginum Hitchc. This species appears to be the same as P. Ghiesbreghtii Fourn. of Mexico.

Panicum laxum Sw. To this was referred P. polygonatum Schrad. which, however, proves to be distinct, and is easily recognized by its pubescent nodes, and by the lack of the swollen sterile palea which characterizes $P$. laxum and $P$. pilosum.

Panicum numidianum Lam. This species appears to be confined to the North African area and, though not well known, is sufficiently distinct from $P$. barbinode Trin. of Cuba and tropical America.

Panicum Rugellii Griseb. = Lasiacis Rugellii (Griseb.).

Panicum Sellovii Nees. An earlier name is P. millegrana Poir.

Panicum Sloanei Griseb.=Lasiacis Sloanei (Griseb.).

Panicum Srartzianum Hitchc. $=$ Lasiacis Swartziana (Hitchc.).

To these may be added the following two corrections in genera allied to Panicum:

Mesosetum rottboellioides (H. B. K.) Hitchc. A comparison of the type specimens shows that the Cuban species is Mesosetum loliiforme (Hochst.) Chase (Panicum loliiforme Hochst. 5 ).

Hymenachne auriculata (Willd.) Chase. The specimen mentioned,

Wright 3863 in part, is $H$. patula Fourn. ${ }^{6}$-A. S. Нiтснсоск, U.S. Department of Agriculture, Washington, D.C.

5 Steud. Syn. Pl. Glum. I:56. I854.

${ }^{6} \mathrm{Mex} . \mathrm{Pl} .2: 37$. 1886. 
